\title{
The Effects of Thermonuclear Reaction Rate Variations on Nova Nucleosynthesis: A Sensitivity Study
}

\author{
Christian Iliadis \\ Department of Physics and Astronomy, The University of North Carolina at Chapel Hill, \\ Chapel Hill, North Carolina 27599-3255; and Triangle Universities Nuclear Laboratory, \\ Durham, North Carolina 27708-0308; iliadis@unc.edu \\ Art Champagne \\ Department of Physics and Astronomy, The University of North Carolina at Chapel Hill, \\ Chapel Hill, North Carolina 27599-3255; and Triangle Universities Nuclear Laboratory, \\ Durham, North Carolina 27708-0308; aec@tunl.duke.edu
}

\author{
Jordi José \\ Departament de Física i Enginyeria Nuclear (UPC), Avinguda Víctor Balaguer, s/n, \\ E-08800 Vilanova i la Geltrú (Barcelona), SPAIN; and Institut d'Estudis Espacials de \\ Catalunya, Edifici Nexus-201, C/Gran Capità 2-4, E-08034 Barcelona, SPAIN; \\ jjose@ieec.fcr.es \\ Sumner Starrfield \\ Department of Physics and Astronomy, Arizona State University, Tempe, Arizona \\ 85287-1504; sumner.starrfield@asu.edu \\ and \\ Paul Tupper \\ Scientific Computing - Computational Mathematics Program, Stanford University, \\ Stanford, California 94305; tupper@sccm.stanford.edu
}

Received accepted 


\begin{abstract}
We investigate the effects of thermonuclear reaction rate uncertainties on nova nucleosynthesis. One-zone nucleosynthesis calculations have been performed by adopting temperature-density-time profiles of the hottest hydrogen-burning zone (i.e., the region in which most of the nucleosynthesis takes place). We obtain our profiles from 7 different, recently published, hydrodynamic nova simulations covering peak temperatures in the range from $\mathrm{T}_{\text {peak }}=0.145-0.418 \mathrm{GK}$. For each of these profiles, we individually varied the rates of 175 reactions within their associated errors and analyzed the resulting abundance changes of 142 isotopes in the mass range below $A=40$. In total, we performed $\approx 7350$ nuclear reaction network calculations. We use the most recent thermonuclear reaction rate evaluations for the mass ranges $A=1-20$ and $A=20-40$. For the theoretical astrophysicist, our results indicate the extent to which nova nucleosynthesis calculations depend on presently uncertain nuclear physics input, while for the experimental nuclear physicist our results represent at least a qualitative guide for future measurements at stable and radioactive ion beam facilities. We find that present reaction rate estimates are reliable for predictions of $\mathrm{Li}, \mathrm{Be}, \mathrm{C}$ and $\mathrm{N}$ abundances in nova nucleosynthesis. However, rate uncertainties of several reactions have to be reduced significantly in order to predict more reliable $\mathrm{O}, \mathrm{F}, \mathrm{Ne}, \mathrm{Na}, \mathrm{Mg}, \mathrm{Al}, \mathrm{Si}, \mathrm{S}, \mathrm{Cl}$ and $\mathrm{Ar}$ abundances. Results are presented in tabular form for each adopted nova simulation.
\end{abstract}

Subject headings: nuclear reactions, nucleosynthesis, abundances - stars: novae 


\section{INTRODUCTION}

Classical novae occur in binary star systems consisting of a white dwarf and a main sequence star. When the companion star fills its Roche lobe, matter passes through the

inner Lagrangian point and accumulates in an accretion disk before falling onto the white dwarf. The accreted layer gradually grows in mass. For sufficiently small mass-accretion rates, the deepest layers of the accreted material become partially degenerate. The temperature in the accumulated envelope increases because of compressional heating and energy release from nuclear reactions until a thermonuclear runaway occurs. At some time during the evolution, material from the white dwarf core is mixed into the accreted hydrogen-rich layer. As a consequence, a significant fraction of material, enriched in the products of hot hydrogen burning, is ejected into the interstellar medium. Spectroscopic studies of classical novae show enrichments of either C, N, O or of certain elements in the range from Ne to Ar (Gehrz et al. 1998, and references therein; Starrfield et al. 1998). The observed abundance patterns have been explained by assuming that the outbursts involve two fundamentally different types of white dwarfs with a composition consisting primarily of either carbon and oxygen $(\mathrm{CO})$ or oxygen and neon $(\mathrm{ONe})$.

The study of classical novae is of considerable interest for several reasons. First, spectroscopic studies of nova ejecta, when properly interpreted, reveal the composition of the underlying white dwarf, thereby constraining models of stellar evolution. Second, the observed elemental abundances also reflect the evolution of the thermonuclear runaway, such as peak temperatures and expansion time scales, and thus provide constraints for models of stellar explosions (Starrfield et al. 1998, 2000). Third, classical novae clearly contribute to the chemical evolution of the Galaxy. In fact, they have been proposed as the major source of the isotopes ${ }^{13} \mathrm{C}$ and ${ }^{17} \mathrm{O}$, and perhaps ${ }^{15} \mathrm{~N}$ (José \& Hernanz 1998). They may also represent a site for production of the cosmologically interesting isotope ${ }^{7} \mathrm{Li}$ 
(Arnould \& Norgaard 1975; Starrfield et al. 1978; Hernanz, José, Coc, \& Isern 1996) as suggested by recent models of Galactic chemical evolution (Romano et al. 1999). Fourth, it is believed that radioactive isotopes are synthesized in nova outbursts. Short-lived isotopes, such as ${ }^{14} \mathrm{O}\left(\tau_{1 / 2}=71 \mathrm{~s}\right),{ }^{15} \mathrm{O}\left(\tau_{1 / 2}=2 \mathrm{~min}\right)$ and ${ }^{17} \mathrm{~F}\left(\tau_{1 / 2}=65 \mathrm{~s}\right)$, can reach the outer layers of the accreted envelope via convection, and their $\beta$-decays provide an important energy source for the ejection of material (Starrfield et al. 1972). The decays of the short-lived nuclei ${ }^{13} \mathrm{~N}\left(\tau_{1 / 2}=10 \mathrm{~min}\right)$ and ${ }^{18} \mathrm{~F}\left(\tau_{1 / 2}=110 \mathrm{~min}\right)$ produce $\gamma$-radiation of $511 \mathrm{keV}$ and below, related to electron-positron annihilation and Compton-scattering, at a time when the expanding envelope becomes transparent to $\gamma$-rays (Gómez-Gomar et al. 1998; Hernanz et al. 1999). The decays of the longer-lived isotopes ${ }^{7} \mathrm{Be}\left(\tau_{1 / 2}=53 \mathrm{~d}\right)$ and ${ }^{22} \mathrm{Na}$ $\left(\tau_{1 / 2}=2.6 \mathrm{y}\right)$ produce $\gamma$-rays with energies of $\mathrm{E}_{\gamma}=478$ and $1275 \mathrm{keV}$, respectively (Clayton \& Hoyle 1974; Leising \& Clayton 1987). Observations of $\gamma$-rays from novae have been attempted with several satellites, but no positive detection has been reported. In the near future, however, novae will be promising targets for more sensitive instruments, such as the International Gamma-Ray Astrophysics Laboratory (INTEGRAL). Fifth, the discovery of ${ }^{26} \mathrm{Al}\left(\tau_{1 / 2}=7.4 \times 10^{5} \mathrm{y}\right)$ in the interstellar medium (Mahoney et al. 1982) provided direct proof that nucleosynthesis is currently active in the Galaxy. ¿From the observed intensity of the $1809 \mathrm{keV} \gamma$-ray line emission, it has been estimated that the production rate of ${ }^{26} \mathrm{Al}$ in the Galaxy is $\approx 2 \mathrm{M}_{\odot}$ per $10^{6} \mathrm{y}$. Although massive stars have been proposed as the main source of ${ }^{26} \mathrm{Al}$ (Diehl et al. 1995; Prantzos \& Diehl 1996; Diehl 1997; Knödlseder 1999), a contribution from classical novae cannot be ruled out (Politano et al. 1995; José, Hernanz, \& Coc 1997). Sixth, the recent discovery of several presolar SiC grains with anomalous $\mathrm{C}, \mathrm{N}, \mathrm{Al}$ and $\mathrm{Si}$ isotopic ratios points towards a nova origin (Amari et al. 2001). If this identification is accurate, then the measured isotopic composition provides important constraints on both the nucleosynthesis and on the conditions in stellar outflows and circumstellar grain formation (Gehrz et al. 1998). 
The thermonuclear runaway model reproduces several key features observed in nova outbursts. At present, the most successful calculations involve one-dimensional hydrodynamic codes that are directly coupled to large nuclear reaction networks (Kovetz \& Prialnik 1997; José \& Hernanz 1998; Starrfield et al. 1998, 2000; and references therein). However, some outstanding problems remain to be solved (Gehrz et al. 1998; José \& Hernanz 1998; Starrfield et al. 1998, 2000). For example, the masses of the underlying white dwarfs are unknown and the rates of mass accretion are poorly constrained. The composition of white dwarfs involved in either $\mathrm{CO}$ or ONe novae is far from understood and may vary from outburst to outburst. The mechanism responsible for the mixing of white dwarf core material into the accreted hydrogen envelope is not universally accepted. The amount of mass ejected is controversial. Finally, many nuclear reaction cross sections entering in the hydrodynamic model calculations are uncertain by orders of magnitude.

In the present work, we focus on the effects of reaction rate uncertainties in nova model calculations. In the past, such effects were frequently ignored by stellar modelers who used only one specific set of recommended reaction rates from available libraries. Reaction rate uncertainties in hydrodynamic nova model calculations have been rarely explored in previous work. These studies were mainly concerned with the effects of a few uncertain reaction rates on the production of specific isotopes of interest, such as ${ }^{18} \mathrm{~F}$ (Coc et al. 2000), ${ }^{22} \mathrm{Na}$ and ${ }^{26} \mathrm{Al}$ (José, Coc, \& Hernanz 1999), and Si-Ca (José, Coc, \& Hernanz 2001). In the present work, we describe a more extensive approach. We independently vary the rates of 175 reactions that participate in nova model nucleosynthesis and analyze the resulting abundance variations of 142 isotopes in the mass range below $A=40$. In our calculations we take advantage of the two most recent thermonuclear reaction rate evaluations for the mass ranges $A=1-20$ (Angulo et al. 1999) and $A=20-40$ (Iliadis et al. 2001). For the theoretical astrophysicist, our results indicate the extent to which the nucleosynthesis depends on presently uncertain nuclear physics input, while for the experimental nuclear physicist 
our results represent at the least a qualitative guide for future measurements at stable or radioactive ion beam facilities.

Our philosophy and general issues related to the present work are described in $\S 2$. In $\S 3$ we explain our strategy and procedures in more detail. Results are presented in $\S 4$ and discussed in $\S 5$. A summary and conclusions are given in $\S 6$.

\section{PHILOSOPHY}

Experimental nuclear physicists frequently inquire about "the most important nuclear reaction to be measured in order to explain the nova phenomenon". Recalling the discussion in the last section, we can state with confidence that a single most important reaction does not exist. Rather, different key reactions are important for different aspects of nova nucleosynthesis. We also need to make an important distinction. Of principle interest is not the identification of the most important nuclear reactions (for example, those which produce most of the energy), but the search for those reaction rate uncertainties which

have the largest impact on nova simulations. It is precisely these reaction rate uncertainties which need to be addressed with significant new measurements.

Modern reaction networks used in nova studies typically involve $\approx 100$ isotopes linked by $\approx 1000$ nuclear reactions and decays. The situation is very complex and intuitive guesses regarding the most important reaction rate uncertainties are inadequate. Clearly, a quantitative approach is needed. Consider as an example a nuclear reaction with a rate uncertainty of a factor of 100 in the temperature range of interest. The most direct approach to investigate the effects of this uncertainty on the overall nucleosynthesis would require several hydrodynamic simulations. The first calculation might be performed with the recommended rate for this particular reaction, while in subsequent calculations the 
rate might be changed by specific factors within the quoted uncertainty. A decision regarding the "importance" of the reaction rate error under consideration can then be based, for example, on the extent of isotopic abundance variations predicted by these calculations. This procedure would then be repeated for all other nuclear reactions which are of potential interest for nova nucleosynthesis. At this point, it has to be kept in mind that a single hydrodynamic nova calculation typically takes several CPU hours on present-day computers. Although the approach described above is useful for a relatively small number of reaction rate changes (José, Coc, \& Hernanz 1999; Coc et al. 2000; José, Coc, \& Hernanz 2001), it is clear that it is not suitable for purposes of the present work because of limitations in computing time.

In the present work, a different approach is utilized. Our calculations are performed with an extended reaction network by using temperature-density-time profiles extracted from recent hydrodynamic nova simulations. The advantage of this procedure is that a single network calculation lasts only a few minutes. This has allowed us to independently vary the rates of 175 reactions by different factors within their uncertainties, and to analyze the resulting abundance variations of 142 isotopes in the mass range below $\mathrm{A}=40$. The procedure is repeated for a number of temperature-density-time profiles obtained from recent hydrodynamic nova simulations involving different white dwarf masses and compositions. In total, we have performed $\approx 7350$ reaction network calculations. We would also like to point out a disadvantage of this procedure. The reaction network is not coupled directly to the hydrodynamics and, consequently, we ignore the important effect of convection on the final nova abundances. As pointed out previously (see, for example, Lazareff et al. 1979 or José \& Hernanz 1998), convective mixing carries material from the hydrogen burning region to the surface on short time scales. This will cause an increase in ejected abundances of fragile nuclei that would have been destroyed, if they had not been carried to higher and cooler layers. Therefore, our calculations are unsuitable for 
defining absolute isotopic abundances resulting from nova nucleosynthesis. However, we claim that our procedure is adequate for exploring the effects of reaction rate uncertainties on abundance changes in the hottest hydrogen burning zone, i.e., the region in which most of the nucleosynthesis takes place. For a few selected cases, we have compared the results of our one-zone (or "co-processing") nucleosynthesis calculations with those obtained by the hydrodynamic code coupled directly to the reaction network. As will be seen, the results are in reasonable agreement. Similar approaches' investigating the nucleosynthesis in solar models (Bahcall et al. 1982) and in massive stars (The et al. 1998; Hoffman, Woosley, \& Weaver 2001) have been reported previously.

Finally, we would like to address an issue which some of us have confronted in the past. One might argue that it is of little use to identify key reaction rate errors since hydrodynamic nova modeling carries significant uncertainties $(\S 1)$. However, it must be emphasized that the abundances observed in nova ejecta or in presolar grains from novae provide strong constraints for nova simulations because nuclear reactions are very sensitive to temperature. Clearly, such constraints are only useful for improving current stellar models if key nuclear reaction rates are known with sufficient accuracy.

\section{STRATEGY}

\footnotetext{
${ }^{1} \mathrm{~A}$ recent article by Hix et al. (2002) also addresses effects of reaction rate uncertainties in nova nucleosynthesis. They assign random errors to each reaction rate in their network by using Monte Carlo techniques. Their procedure represents a complementary approach to a similar problem.
} 


\subsection{Nuclear Reaction Network}

The nuclear reaction network used in the present work follows the detailed evolution of 142 stable and proton-rich isotopes from hydrogen to calcium. For the physical conditions achieved by the nova models adopted in our work, this network is appropriate for nucleosynthesis calculations. The assumption is supported by the fact that overabundances of elements beyond calcium are not observed in nova ejecta. The nuclei are linked by 1265 nuclear processes including weak interactions, reactions of type $(\mathrm{p}, \gamma),(\mathrm{p}, \alpha),(\alpha, \gamma)$ etc., and corresponding reverse reactions.

For the construction of the thermonuclear reaction rate library we have used, with few exceptions, the most recent compiled and evaluated results given in Angulo et al. (1999) and Iliadis et al. (2001) for the mass ranges $A=1-20$ and $A=20-40$, respectively. For the reactions ${ }^{8} \mathrm{~B}(\mathrm{p}, \gamma){ }^{9} \mathrm{C} 2,{ }^{9} \mathrm{C}(\alpha, \mathrm{p}){ }^{12} \mathrm{~N},{ }^{8} \mathrm{~B}(\alpha, \mathrm{p}){ }^{11} \mathrm{C},{ }^{11} \mathrm{C}(\mathrm{p}, \gamma){ }^{12} \mathrm{~N}$ and ${ }^{12} \mathrm{~N}(\mathrm{p}, \gamma){ }^{13} \mathrm{O}$ we used the reaction rates of Wiescher et al. (1989). For the reaction ${ }^{17} \mathrm{~F}(\mathrm{p}, \gamma){ }^{18} \mathrm{Ne}$ we adopted the results of Bardayan et al. (2000), while for ${ }^{17} \mathrm{O}(\mathrm{p}, \gamma){ }^{18} \mathrm{~F}$ and ${ }^{17} \mathrm{O}(\mathrm{p}, \alpha){ }^{14} \mathrm{~N}$ we made use of the rates from Blackmon et al. (2001). The reaction rates for ${ }^{18} \mathrm{~F}(\mathrm{p}, \gamma){ }^{19} \mathrm{Ne}$ and ${ }^{18} \mathrm{~F}(\mathrm{p}, \alpha){ }^{15} \mathrm{O}$ were taken from Coc et al. (2000). For the reactions ${ }^{13} \mathrm{C}(\mathrm{p}, \gamma){ }^{14} \mathrm{~N},{ }^{14} \mathrm{~N}(\mathrm{p}, \gamma){ }^{15} \mathrm{O}$, ${ }^{16} \mathrm{O}(\mathrm{p}, \gamma){ }^{17} \mathrm{~F},{ }^{18} \mathrm{O}(\mathrm{p}, \alpha){ }^{15} \mathrm{~N},{ }^{19} \mathrm{~F}(\mathrm{p}, \gamma){ }^{20} \mathrm{Ne},{ }^{19} \mathrm{Ne}(\mathrm{p}, \gamma){ }^{20} \mathrm{Na},{ }^{15} \mathrm{O}(\alpha, \gamma){ }^{19} \mathrm{Ne}$ and ${ }^{14} \mathrm{O}(\alpha, \mathrm{p}){ }^{17} \mathrm{~F}$ we still employ the rates from Caughlan \& Fowler (1988) since changes in recent updates are small (less than 30\%). Our network also includes all $\beta$-delayed proton and $\alpha$-particle

\footnotetext{
${ }^{2}$ The astrophysical S-factor for this reaction has been estimated recently by measuring the proton-transfer ${ }^{8} \mathrm{~B}(\mathrm{~d}, \mathrm{n}){ }^{9} \mathrm{C}$ (Beaumel et al. 2001). The new reaction rate estimate is smaller by a factor of 4 compared to the results of Wiescher et al. (1989) which are used in the present work. This difference is unimportant for nova nucleosynthesis (see $\S 5$ ).

${ }^{3}$ Consider, for example, the positron decay of ${ }^{29} \mathrm{~S}$. Previous network calculations included only the link ${ }^{29} \mathrm{~S} \rightarrow{ }^{29} \mathrm{P}$ which represents the $\beta$-decay to the ${ }^{29} \mathrm{P}$ ground state. However, the
} 
decays in the mass range of interest. All partial half-lives for $\beta$-decays and $\beta$-delayed decays have been adopted from the recent NUBASE evaluation (Audi et al. 1997). The ground and isomeric state of ${ }^{26} \mathrm{Al}$ have been treated as separate nuclei (Ward \& Fowler 1980) and the communication between those states through thermal excitations involving higher-lying excited ${ }^{26} \mathrm{Al}$ levels has been taken into account explicitly. The required $\gamma$-ray transition probabilities have been adopted from Runkle et al. (2001). The library used here for nucleosynthesis calculations for the mass range $\mathrm{A} \leq 40$ is, in our opinion, the most recent and consistent set of thermonuclear reaction rates available at present.

\subsection{Temperature-Density Evolution and Initial Composition}

In addition to the information described above, our one-zone reaction network calculations require assumptions regarding the evolution of temperature and density, and the initial envelope composition.

In the present work, we have used temperature-density-time profiles of the hottest hydrogen burning zone, obtained from recently published hydrodynamic nova simulations. Properties of these evolutionary nova models are summarized in Table 1 and are described in detail elsewhere (Politano et al. 1995; José, Coc, \& Hernanz 1999; Starrfield et al. 2002). Stellar evolution theory predicts that the masses of $\mathrm{CO}(\mathrm{ONe})$ white dwarfs are smaller (larger) than $\approx 1.1 \mathrm{M}_{\odot}$. Therefore, we have considered several models of CO and ONe novae with white dwarf masses of $0.8-1.0 \mathrm{M}_{\odot}$ and $1.15-1.35 \mathrm{M}_{\odot}$, respectively. The corresponding

nucleus ${ }^{29} \mathrm{~S}$ also $\beta$-decays with about equal probability to excited ${ }^{29} \mathrm{P}$ states which are unbound. These levels decay subsequently via proton emission, leading to the final nucleus ${ }^{28} \mathrm{Si}$. Clearly, the $\beta$-decay ${ }^{29} \mathrm{~S} \rightarrow{ }^{29} \mathrm{P}$ and the $\beta$-delayed proton decay ${ }^{29} \mathrm{~S} \rightarrow{ }^{28} \mathrm{Si}$ compete with each other and have to be treated as separate links in the network. 
temperature-density-time profiles are displayed in Figure 1. Note, that ONe nova model S1 of Starrfield et al. (2002) was calculated with the same thermonuclear reaction rate library as used in the present work, while the nova models of Politano et al. (1995) and José, Coc, \& Hernanz (1999) were calculated with previous reaction rate libraries.

Our network calculations, for a specific temperature-density-time profile, have been performed with the same initial isotopic composition as was used in the corresponding hydrodynamic nova simulation (Table 1). Initial isotopic abundances (in mass fractions) for the nova models considered here are listed in Table 2 and are also displayed in Figure 2. We would like to point out that the initial abundances employed in the ONe nova models of Politano et al. (1995) and Starrfield et al. (2002) differ significantly from those of José, Coc, \& Hernanz (1999). Therefore, we are also studying the effects of different initial compositions on the final abundance changes.

\subsection{Reaction Rate Errors and Reaction Rate Variations}

The investigation of reaction rate sensitivities in nova nucleosynthesis requires the variation of reaction rates within their respective uncertainties. Therefore, quantitative

estimates of reaction rate errors are needed. For a subset of reactions considered here, we list in Table 3 reaction rate errors adopted in the present work. For most reaction rates involving stable or long-lived target nuclei the errors were taken from either Angulo et al. (1999) or from Iliadis et al. (2001). For ${ }^{17} \mathrm{O}+\mathrm{p}$ we use the errors of Blackmon et al. (2001), since new experimental results have become available. The reader should realize that it is frequently difficult to assign errors to reaction rates. This situation arises, for example, if Hauser-Feshbach theory is used to calculate a reaction rate, or if a reaction involves a 
short-lived target nucleus. In the former casef, we have generally assumed that reaction rate errors amount to a factor of 100 up and down. The same assumption has been made in the latter case as well, with a few important exceptions. The reaction ${ }^{8} \mathrm{~B}(\mathrm{p}, \gamma){ }^{9} \mathrm{C}$ has not been measured directly, but the corresponding reaction rates can be estimated by using results of a recent proton-transfer reaction study (Beaumel et al. 2001). In this case we assumed a conservative reaction rate error of a factor of 10 . For the ${ }^{13} \mathrm{~N}(\mathrm{p}, \gamma){ }^{14} \mathrm{O}$ reaction rates we adopted the errors of Angulo et al. (1999), while for ${ }^{18} \mathrm{~F}(\mathrm{p}, \gamma){ }^{19} \mathrm{Ne}$ and ${ }^{18} \mathrm{~F}(\mathrm{p}, \alpha){ }^{15} \mathrm{O}$ we used the errors of Coc et al. (2000). Bardayan et al. (2000) report an error of only $15 \%$ for the ${ }^{17} \mathrm{~F}(\mathrm{p}, \gamma){ }^{18} \mathrm{Ne}$ reaction rates at nova temperatures. However, it must be emphasized that the proton capture reaction on ${ }^{17} \mathrm{~F}$ has not been measured. In our opinion, an error of a factor of 10 is a more realistic estimate. Finally, Iliadis et al. (1999) report reaction rate errors of a factor of 2 for the proton captures on ${ }^{27} \mathrm{Si},{ }^{31} \mathrm{~S},{ }^{35} \mathrm{Ar}$ and ${ }^{39} \mathrm{Ca}$. In the present work, we adopted a more conservative error of a factor 10. In some cases, reaction rate uncertainties are not constant but depend on stellar temperature (for example, see Figs. 2-4 in Iliadis et al. 2001). If a reaction rate error varied significantly with temperature, for the sake of simplicity we have adopted in our network calculations the maximum reaction rate error in the temperature range of interest to nova nucleosynthesis ( $\mathrm{T}=0.1-0.4 \mathrm{GK})$. This assumption is conservative since it can overestimate some of our predicted abundance changes.

Among the 1265 nuclear processes included in our network, we varied the rates of 175 selected reactions. Those included all exothermic $(\mathrm{p}, \gamma)$ and $(\mathrm{p}, \alpha)$ reactions and the most

\footnotetext{
${ }^{4}$ The reactions of interest here involve light target nuclei $(\mathrm{A} \leq 40)$ and have small $\mathrm{Q}^{-}$ values $(\mathrm{Q} \leq 10 \mathrm{MeV})$. Therefore, we expect Hauser-Feshbach reaction rates to provide results in excess of the usually quoted "factor of 2 reliability" (Hoffman et al. 1999; Rauscher \& Thielemann 2000). This point has been discussed in more detail by Iliadis et al. (2001).
} 
important $(\alpha, \gamma)$ and $(\alpha, \mathrm{p})$ reactions, on stable and proton-rich target nuclei with masses $\mathrm{A} \leq 40$. Only a subset of 62 reactions is listed in Table 3. The rates of those 175 reactions, together with the corresponding reverse reaction rates, have been varied individually by factors of 100, 10, 2, 0.5, 0.1 and 0.01 in successive reaction network calculations. Since we have explored nova nucleosynthesis for seven different temperature-density-time profiles (Table 1 ), a total of $175 \times 6 \times 7=7350$ network calculations were performed.

\section{RESULTS}

For each network calculation, the final abundances of 142 isotopes were analyzed. Short-lived isotopes (e.g., ${ }^{13} \mathrm{~N},{ }^{14} \mathrm{O},{ }^{15} \mathrm{O}$ and ${ }^{17} \mathrm{~F}$ ) present at the end of a network calculation were assumed to decay to their stable daughter nuclei.

In Table 4 we list the final isotopic abundances (in mass fractions) for each temperature-density-time profile considered in the present work (Table 1). These results have been obtained by using recommended rates for all reactions in our network, as discussed in $\S \S 3.1$. We emphasize again that, for reasons given in $\S 2$, the abundances presented in Table 4 should not be directly compared to abundances observed in nova ejecta or to those obtained from a full hydrodynamic calculation. Table 4 is mainly useful for the purpose of comparing final abundances from different one-zone nucleosynthesis calculations.

The results of our reaction rate variation procedure are presented in Tables $5-11$. For each temperature-density-time profile we list in column (1) the reaction whose rate has been varied, in column (2) the isotope i whose abundance changed because of the rate variation, and in columns (3)-(8) the factor change, $\mathrm{X}_{i} / \mathrm{X}_{i, r e c}$, in final isotopic abundance for rate variations by factors of $100,10,2,0.5,0.1$ and 0.01 . Specifically, $\mathrm{X}_{i, r e c}$ refers to the final isotopic abundance of isotope i obtained from a network calculation involving 
recommended rates only; $\mathrm{X}_{i}$ refers to the final isotopic abundance of isotope i obtained from a network calculation in which the rate of a single reaction (listed in column 1) has been multiplied by a specific factor. Only significant final abundance changes are presented. Results have been listed only if i) a final abundance changed by at least $10 \%$ compared to the reference calculation performed with our recommended reaction rate library (§§ 3.1), and ii) the reaction rate was varied by a factor less than (or close to) the assigned reaction rate error (Table 3). In Figure 3 we display the results of reaction rate variations for a few selected cases only. Our results are discussed in $\S 5$.

\section{DISCUSSION}

We start the discussion with two necessary (but not sufficient) conditions that have to be fullfilled for the experimental nuclear physicist in order to perform a meaningful new measurement of a particular nuclear reaction. First, the nuclear reaction must have a significant influence on a stellar model property that can be related to an astronomical observable. Second, the nuclear reaction rate must have an error giving rise to a significant uncertainty of a stellar model property. The observable could be an isotopic abundance, a luminosity or a mass ejection velocity. In this section we will not attempt to discuss all of the results listed in Tables 5-11, but concentrate on those cases for which the two conditions outlined above apply.

As a first example, we consider the ${ }^{39} \mathrm{~K}(\mathrm{p}, \gamma){ }^{40} \mathrm{Ca}$ reaction. According to Table 3, we assign a factor of 100 uncertainty to the reaction rate. Increasing the recommended rate for this reaction by a factor of 100 decreases the final ${ }^{39} \mathrm{~K}$ abundance in all of our ONe nova network calculations by more than an order of magnitude. However, potassium has not yet been observed in nova ejecta. In this case, the first condition is not fullfilled and, therefore,

calculated potassium abundances are unimportant for testing current nova models. We will 
not discuss such cases further. Nevertheless, the results are listed in Tables $5-11$ since future observations of nova ejecta could perhaps reveal the presence of elements like potassium.

As another example, consider the ${ }^{20} \mathrm{Ne}(\mathrm{p}, \gamma)^{21} \mathrm{Na}$ reaction. The error for this rate is about $70 \%$ (Table 3). Rate variations by factors of 2 and 0.5 produce final abundance changes for any isotope of less than a factor of 2. These calculated abundance changes are close to present uncertainties of observed abundances in nova ejecta. In this case, the second condition is not fullfilled and, consequently, it is unlikely that a new and improved measurement of this reaction will provide additional constraints for current nova models. Again, we do not discuss such cases further but list the results in Tables 5-11 since abundances observed in nova ejecta are likely to become more precise in the future.

It is important to point out that the reaction-rate variations performed in the present work have only a minor influence on the amount of hydrogen consumed, the amount of helium produced, and the total thermonuclear energy released. In the following, we will focus on final isotopic abundance changes of those elements that are considered the most

important for nova nucleosynthesis $\left({ }^{7} \mathrm{Li},{ }^{7} \mathrm{Be}, \mathrm{C}, \mathrm{N}, \mathrm{O},{ }^{18} \mathrm{~F}, \mathrm{Ne}, \mathrm{Na}, \mathrm{Mg}, \mathrm{Al}, \mathrm{Si}, \mathrm{S}, \mathrm{Cl}\right.$ and Ar; see $\S 1$ ). The variation of reaction rates within their assigned error in the temperature range $\mathrm{T}=0.1-0.4 \mathrm{GK}$ ( $\S 3.3$ and Table 3 ) will be referred to simply as "reaction rate variations". When using the expression "abundance" we mean more specifically the final isotopic abundance obtained at the end of a network calculation. Furthermore, we have regarded abundance changes as significant only if they amount to at least a factor of 2 . The mass regions $\mathrm{A}<20$ and $\mathrm{A} \geq 20$ are discussed separately in the next subsections.

\subsection{Mass Region $\mathrm{A}<20$}




\subsubsection{Isotopes ${ }^{7} \mathrm{Li}$ and ${ }^{7} \mathrm{Be}$}

In explosive hydrogen burning, the isotope ${ }^{7} \mathrm{Li}$ is produced by the decay of ${ }^{7} \mathrm{Be}$.

The isotopic abundance of ${ }^{7} \mathrm{Be}$ depends only weakly on reaction rate variations in $\mathrm{CO}$ nova models. Abundance changes amount to less than a factor of 2 and, therefore, cannot be regarded as significant.

In ONe nova models $\mathrm{P} 1$ and $\mathrm{P} 2$, the abundance of ${ }^{7} \mathrm{Be}$ is also insensitive to reaction rate variations. For models JCH1 and JCH2, the ${ }^{7} \mathrm{Be}$ abundance changes by less than a factor of 2 as a result of varying the ${ }^{7} \mathrm{Be}(\mathrm{p}, \gamma)$ reaction rates within adopted errors (Table 3 ). Only in model S1, which achieves the highest peak temperature, the ${ }^{7} \mathrm{Be}$ abundance changes by a factor of $\leq 20$ as a result of ${ }^{8} \mathrm{~B}(\mathrm{p}, \gamma)$ reaction rate variations. However, we emphasize that ${ }^{7} \mathrm{Be}$ is a very fragile nucleus which is easily destroyed at high stellar temperatures. In this particular case, convection plays a crucial role as pointed out by Hernanz et al. (1996). Consequently, the ${ }^{7} \mathrm{Be}$ abundance could be far less sensitive to ${ }^{8} \mathrm{~B}(\mathrm{p}, \gamma)$ reaction rate variations in a hydrodynamic nova simulation. Such studies are underway and the results will be reported in a forthcoming publication (Starrfield et al. 2002).

We conclude that for nova models, with the possible exception of ONe nova model S1, estimates of Galactic ${ }^{7} \mathrm{Li}$ production and of the $478 \mathrm{keV} \gamma$-ray line intensity from ${ }^{7} \mathrm{Be}$ decay are insensitive to present reaction rate uncertainties.

\footnotetext{
${ }^{5}$ Abundance changes of ${ }^{7} \mathrm{Be}$ as a result of ${ }^{7} \mathrm{Be}(\mathrm{p}, \gamma)$ reaction rate variations, as listed in Tables 8 and 9 , are rather large. Note, that the listed values correspond to a factor of 2 variation in the reaction rates. However, the adopted ${ }^{7} \mathrm{Be}(\mathrm{p}, \gamma)$ reaction rate error amounts only to $12 \%$ (Table 3 ), yielding a ${ }^{7} \mathrm{Be}$ abundance change of less than a factor of 2 .
} 


\subsubsection{Carbon Isotopes}

Models of ONe novae assume small initial ${ }^{12} \mathrm{C}$ abundances, while the opposite is the case for CO nova models (Table 2). Therefore, we expect the final carbon isotopic abundances in $\mathrm{ONe}$ and $\mathrm{CO}$ nova models to depend on the rates of different reactions. This is indeed the case, as can be seen from Tables $5-11$. The ${ }^{12} \mathrm{C}$ and ${ }^{13} \mathrm{C}$ isotopic abundances show a dependence on reaction rate variations of ${ }^{13} \mathrm{~N}(\mathrm{p}, \gamma),{ }^{17} \mathrm{O}(\mathrm{p}, \gamma),{ }^{17} \mathrm{O}(\mathrm{p}, \alpha)$ and ${ }^{17} \mathrm{~F}(\mathrm{p}, \gamma)$ in ONe nova models, and of ${ }^{12} \mathrm{C}(\mathrm{p}, \gamma),{ }^{13} \mathrm{C}(\mathrm{p}, \gamma)$ and ${ }^{14} \mathrm{~N}(\mathrm{p}, \gamma)$ in $\mathrm{CO}$ nova models. However, the abundances change by less than $50 \%$ in all nova models considered in the present work.

Present reaction rate estimates seem to be reliable for predicting carbon abundances in nova ejecta and ${ }^{12} \mathrm{C} /{ }^{13} \mathrm{C}$ isotopic abundance ratios of presolar grains originating from novae.

\subsubsection{Nitrogen Isotopes}

Abundances of the isotopes ${ }^{14} \mathrm{~N}$ and ${ }^{15} \mathrm{~N}$ show a dependence on reaction rate variations of ${ }^{13} \mathrm{~N}(\mathrm{p}, \gamma),{ }^{14} \mathrm{~N}(\mathrm{p}, \gamma),{ }^{15} \mathrm{~N}(\mathrm{p}, \alpha),{ }^{17} \mathrm{O}(\mathrm{p}, \gamma),{ }^{17} \mathrm{O}(\mathrm{p}, \alpha),{ }^{17} \mathrm{~F}(\mathrm{p}, \gamma)$ and ${ }^{18} \mathrm{~F}(\mathrm{p}, \alpha)$. The relative importance of these reactions depends on the particular nova model considered. However, as was the case for carbon, changes in nitrogen abundances amount to less than $50 \%$ in all models.

Therefore, current reaction rates are sufficiently reliable for predictions of nitrogen abundances in nova ejecta and of ${ }^{14} \mathrm{~N} /{ }^{15} \mathrm{~N}$ abundance ratios of presolar grains originating from novae. 


\subsubsection{Oxygen Isotopes}

For CO nova models, oxygen abundances show a weak dependence on variations in ${ }^{16} \mathrm{O}(\mathrm{p}, \gamma)$ and ${ }^{17} \mathrm{O}(\mathrm{p}, \gamma)$ reaction rates, with abundance changes of less than a factor of two. However, ${ }^{17} \mathrm{O}$ abundances are sensitive to the ${ }^{17} \mathrm{O}(\mathrm{p}, \alpha)$ reaction rate. Variations of the corresponding reaction rates give rise to ${ }^{17} \mathrm{O}$ abundance changes by factors of $\leq 30$.

In ONe nova models $\mathrm{P} 1, \mathrm{P} 2$ and $\mathrm{S} 1$, variations in ${ }^{18} \mathrm{~F}(\mathrm{p}, \alpha)$ reaction rates change ${ }^{16} \mathrm{O}$ abundances by factors of $\leq 50$. Abundances of ${ }^{17} \mathrm{O}$ are sensitive to reaction rate variations of ${ }^{17} \mathrm{~F}(\mathrm{p}, \gamma)$ in models JCH2, P1, P2, and S1, resulting in abundance changes by factors of $\leq 500$. In models JCH1, JCH2 and P1, the abundance of ${ }^{17} \mathrm{O}$ changes by factors of $\leq 170$ as a result of varying the ${ }^{17} \mathrm{O}(\mathrm{p}, \alpha)$ reaction rates. The ${ }^{17} \mathrm{O}$ abundance is also influenced by rate variations of ${ }^{17} \mathrm{O}(\mathrm{p}, \gamma)$ in models $\mathrm{JCH} 1$ and $\mathrm{JCH} 2$, and of ${ }^{18} \mathrm{~F}(\mathrm{p}, \alpha)$ in model $\mathrm{S} 1$, resulting in abundance changes by factors of $\leq 6$ and $\leq 15$, respectively. Note, that the final abundance of ${ }^{18} \mathrm{O}$ originates predominantly from the decay of ${ }^{18} \mathrm{~F}$ and, therefore, the abundance changes of both isotopes will depend on the rates of the same reactions. The isotope ${ }^{18} \mathrm{~F}$ is discussed below.

Clearly, the rates of several reactions have to be improved in order to predict both more reliable oxygen abundances in nova ejecta and ${ }^{16} \mathrm{O} /{ }^{17} \mathrm{O}$ ratios of presolar grains originating from novae.

\subsubsection{Isotope ${ }^{18} \mathrm{~F}$}

For CO nova models, ${ }^{18} \mathrm{~F}$ abundances are sensitive to ${ }^{18} \mathrm{~F}(\mathrm{p}, \alpha),{ }^{17} \mathrm{O}(\mathrm{p}, \alpha)$ and ${ }^{17} \mathrm{O}(\mathrm{p}, \gamma)$ reaction rate variations, yielding abundance changes by factors of $\leq 100$.

For all ONe nova models considered here, ${ }^{18} \mathrm{~F}$ abundances depend sensitively on variations in ${ }^{17} \mathrm{O}(\mathrm{p}, \gamma)$ and ${ }^{18} \mathrm{~F}(\mathrm{p}, \alpha)$ reaction rates, with abundance changes by factors of 


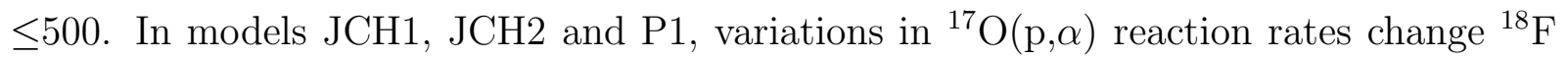
abundances by factors of $\leq 110$. The ${ }^{17} \mathrm{~F}(\mathrm{p}, \gamma)$ reaction also influences the ${ }^{18} \mathrm{~F}$ abundance in models JCH2, P1, P2 and S1, resulting in abundance changes by factors of $\leq 600$.

In summary, the ${ }^{18} \mathrm{~F}$ abundance is sensitive to present reaction rate uncertainties in all nova models considered here. Consequently, the rates of several reactions have to be improved in order to predict with more confidence the early $\gamma$-ray emission from novae at and below $511 \mathrm{keV}$.

\subsection{Mass Region $\mathrm{A} \geq \mathbf{2 0}$}

\subsubsection{Neon Isotopes}

Isotopic abundances of ${ }^{20} \mathrm{Ne}$ and ${ }^{21} \mathrm{Ne}$ depend only weakly on reaction rate variations in $\mathrm{CO}$ nova models. The ${ }^{22} \mathrm{Ne}$ abundance is sensitive to ${ }^{22} \mathrm{Ne}(\mathrm{p}, \gamma)$ reaction rate variations. Corresponding abundance changes amount to factors of $\leq 100$.

For ONe nova models, effects of reaction rate variations on the isotopic abundances of ${ }^{20} \mathrm{Ne},{ }^{21} \mathrm{Ne}$ and ${ }^{22} \mathrm{Ne}$ depend on the peak temperature achieved (Table 1). For model S1, which achieves the highest peak temperature, the abundance of the isotope ${ }^{20} \mathrm{Ne}$ is sensitive to variations of ${ }^{23} \mathrm{Na}(\mathrm{p}, \gamma)$ and ${ }^{23} \mathrm{Mg}(\mathrm{p}, \gamma)$ reaction rates. Abundance changes amount to

factors of $\leq 11$. Abundances of ${ }^{21} \mathrm{Ne}$ are sensitive to reaction rate variations of ${ }^{21} \mathrm{Na}(\mathrm{p}, \gamma)$ in model P2 and of ${ }^{21} \mathrm{Na}(\mathrm{p}, \gamma),{ }^{23} \mathrm{Na}(\mathrm{p}, \gamma)$ and ${ }^{23} \mathrm{Mg}(\mathrm{p}, \gamma)$ in model $\mathrm{S} 1$, resulting in abundance changes by factors of $\leq 13$. The ${ }^{22} \mathrm{Ne}$ abundance is sensitive to ${ }^{22} \mathrm{Ne}(\mathrm{p}, \gamma)$ reaction rate variations in models $\mathrm{JCH} 1, \mathrm{JCH} 2$ and $\mathrm{P} 1$, and to ${ }^{21} \mathrm{Na}(\mathrm{p}, \gamma)$ reaction rate variations in model P2. These abundance changes amount to several orders-of-magnitude.

The dominant neon isotope in nova ejecta is ${ }^{20} \mathrm{Ne}$. In most nova models, its abundance is insensitive to present reaction rate uncertainties. Only ONe nova models which achieve 
very high peak temperatures (for example, model S1) require improved reaction rates for the prediction of accurate ${ }^{20} \mathrm{Ne}$ abundances. Calculations of ${ }^{20} \mathrm{Ne} /{ }^{21} \mathrm{Ne}$ and ${ }^{20} \mathrm{Ne} /{ }^{22} \mathrm{Ne}$ isotopic ratios of presolar grains originating from ONe novae also require improved rates for several reactions.

\subsubsection{Sodium Isotopes}

The ${ }^{22} \mathrm{Na}$ abundance predicted by $\mathrm{CO}$ nova models depends only weakly on reaction rate variations. Furthermore, only small amounts of ${ }^{22} \mathrm{Na}$ are produced as compared to ONe nova models which are discussed below. The ${ }^{23} \mathrm{Na}$ abundance is sensitive to ${ }^{22} \mathrm{Ne}(\mathrm{p}, \gamma)$ reaction rate variations. Corresponding abundance changes amount to factors of $\leq 7$.

For ONe nova models JCH1, JCH2 and P1, reaction rate variations have only minor effects on ${ }^{22} \mathrm{Na}$ abundances. In models P2 and S1, which achieve the highest peak temperatures, variations of ${ }^{21} \mathrm{Na}(\mathrm{p}, \gamma)$ reaction rates have the effect of changing ${ }^{22} \mathrm{Na}$ abundances by factors of $\approx 6$. Variations in ${ }^{23} \mathrm{Na}(\mathrm{p}, \gamma)$ and ${ }^{23} \mathrm{Mg}(\mathrm{p}, \gamma)$ reaction rates have also an effect in model S1, changing ${ }^{22} \mathrm{Na}$ abundances by factors of $\leq 10$. The ${ }^{23} \mathrm{Na}$ abundance is sensitive to ${ }^{23} \mathrm{Na}(\mathrm{p}, \gamma)$ reaction rate variations in all ONe nova models, resulting in abundance changes by factors of $\leq 6$. In models P2 and $\mathrm{S} 1$, the ${ }^{23} \mathrm{Na}$ abundance changes by factors of $\leq 7$ if the ${ }^{23} \mathrm{Mg}(\mathrm{p}, \gamma)$ reaction rates are varied within their errors.

For ONe nova models which achieve high peak temperatures, improved rates for several reactions are desirable for estimating the intensity of the $\gamma$-ray line at $1275 \mathrm{keV}$ originating from the decay of ${ }^{22} \mathrm{Na}$. Furthermore, present reaction rate uncertainties have to be reduced in order to calculate reliable ${ }^{23} \mathrm{Na}$ abundances in $\mathrm{CO}$ and $\mathrm{ONe}$ nova ejecta. 


\subsubsection{Magnesium Isotopes}

For CO nova models, variations of ${ }^{22} \mathrm{Ne}(\mathrm{p}, \gamma)$ and ${ }^{23} \mathrm{Na}(\mathrm{p}, \gamma)$ reaction rates change ${ }^{24} \mathrm{Mg}$ abundances by factors of $\leq 70$. The ${ }^{25} \mathrm{Mg}$ abundance depends on the ${ }^{22} \mathrm{Ne}(\mathrm{p}, \gamma)$ reaction rate in model JH2, resulting in abundance changes by factors of $\leq 5$. Variation of the rates for ${ }^{26} \mathrm{Mg}(\mathrm{p}, \gamma)$ changes the abundance of ${ }^{26} \mathrm{Mg}$ by factors of $\leq 14$.

For all ONe nova models considered here, variations of ${ }^{23} \mathrm{Na}(\mathrm{p}, \gamma)$ reaction rates change the abundances of ${ }^{24} \mathrm{Mg},{ }^{25} \mathrm{Mg}$ and ${ }^{26} \mathrm{Mg}$ by factors of $\leq 60$. In models P2 and $\mathrm{S} 1$, which

achieve the highest peak temperatures, the ${ }^{24} \mathrm{Mg}$ abundance depends also on ${ }^{23} \mathrm{Mg}(\mathrm{p}, \gamma)$ reaction rate variations, resulting in abundance changes by factors of $\leq 7$. In all $\mathrm{ONe}$ nova models, the ${ }^{26} \mathrm{Mg}$ abundance changes by factors of $\leq 14$ as a result of ${ }^{26} \mathrm{Al}^{m}(\mathrm{p}, \gamma)$ reaction rate variations. In models $\mathrm{JCH} 1$ and $\mathrm{JCH} 2$, the ${ }^{26} \mathrm{Mg}$ abundance is also sensitive to ${ }^{26} \mathrm{Mg}(\mathrm{p}, \gamma)$ rate variations. Corresponding abundance changes amount to factors of $\leq 8$. Note, that all reaction rate variations tend to decrease magnesium isotopic abundances.

In summary, several reaction rate uncertainties have to be reduced in order to calculate accurate magnesium isotopic abundances.

\subsubsection{Aluminum Isotopes}

Variations of ${ }^{22} \mathrm{Ne}(\mathrm{p}, \gamma)$ and ${ }^{26} \mathrm{Al}^{g}(\mathrm{p}, \gamma)$ reaction rates change ${ }^{26} \mathrm{Al}$ abundances by factors of $\leq 20$ and $\leq 5$, respectively. However, $\mathrm{CO}$ nova models produce smaller amounts of ${ }^{26} \mathrm{Al}$ compared to ONe models which are discussed below. The abundance of ${ }^{27} \mathrm{Al}$ depends only weakly on reaction rate variations in $\mathrm{CO}$ nova models.

For all ONe nova models, ${ }^{26} \mathrm{Al}$ abundances are sensitive to ${ }^{23} \mathrm{Na}(\mathrm{p}, \gamma)$ and ${ }^{26} \mathrm{Al}^{g}(\mathrm{p}, \gamma)$ reaction rate variations, yielding abundance changes by factors of $\leq 60$. Variations in ${ }^{23} \mathrm{Na}(\mathrm{p}, \gamma)$ reaction rates change ${ }^{27} \mathrm{Al}$ abundances by factors of $\leq 60$. 
Clearly, certain reaction rates have to be improved in order to predict not only more reliable aluminum abundances in nova ejecta, but also to estimate the contribution of novae to the Galactic ${ }^{26} \mathrm{Al}$ abundance and ${ }^{26} \mathrm{Al} /{ }^{27} \mathrm{Al}$ ratios of presolar grains originating from novae.

\subsubsection{Silicon Isotopes}

The nucleosynthesis of silicon isotopes in CO nova models is negligible and reaction rate variations have only insignificant effects.

For all ONe nova models considered, the ${ }^{28} \mathrm{Si}$ abundance is insensitive to reaction rate variations. All models predict a dependence of ${ }^{29} \mathrm{Si}$ abundances on ${ }^{29} \mathrm{Si}(\mathrm{p}, \gamma)$ reaction rate

variations, with abundance changes by factors of $\leq 14$. In all models, variations in ${ }^{30} \mathrm{P}(\mathrm{p}, \gamma)$ reaction rates have the effect of changing ${ }^{30} \mathrm{Si}$ abundances by factors of $\leq 100$.

In conclusion, improved rates for several reactions are desirable in ONe nova models in order to estimate accurate silicon abundances in nova ejecta and silicon isotopic ratios of presolar grains originating from novae.

\subsubsection{Sulfur Isotopes}

Similar to the case of silicon, the nucleosynthesis of sulfur isotopes in CO nova models is negligible.

For ONe nova models JCH1, JCH2, P1 and P2, reaction rate variations of ${ }^{30} \mathrm{P}(\mathrm{p}, \gamma)$ have the effect of changing ${ }^{32} \mathrm{~S}$ abundances by factors of $\leq 12$. For all models, variations in ${ }^{33} \mathrm{~S}(\mathrm{p}, \gamma)$ reaction rates change ${ }^{33} \mathrm{~S}$ abundances by factors of $\leq 1000$. The ${ }^{33} \mathrm{~S}$ abundance also depends on reaction rate variations of ${ }^{30} \mathrm{P}(\mathrm{p}, \gamma)$ in models JCH1, JCH2, P1 and P2, 
and of ${ }^{33} \mathrm{Cl}(\mathrm{p}, \gamma)$ in models P2 and S1. Abundance changes amount to factors of $\leq 14$. The ${ }^{34} \mathrm{~S}$ abundance depends in all models on ${ }^{34} \mathrm{~S}(\mathrm{p}, \gamma)$ reaction rate variations, resulting in abundance changes by factors of $\leq 130$. The ${ }^{34} \mathrm{~S}$ abundance also depends on reaction rate variations of ${ }^{30} \mathrm{P}(\mathrm{p}, \gamma)$ in models JCH2, P1 and $\mathrm{P} 2$, of ${ }^{33} \mathrm{~S}(\mathrm{p}, \gamma)$ in models JCH2, P1, P2 and $\mathrm{S} 1$, and of ${ }^{34} \mathrm{Cl}(\mathrm{p}, \gamma)$ in models $\mathrm{P} 2$ and $\mathrm{S} 1$. Abundance changes amount to factors of $\leq 13$, $\leq 30$ and $\leq 5$, respectively.

Consequently, uncertainties of several reaction rates have to be reduced in ONe nova models for the prediction of accurate sulfur abundances in nova ejecta and of sulfur isotopic ratios of presolar grains originating from novae.

\subsubsection{Chlorine Isotopes}

Variations in ${ }^{34} \mathrm{~S}(\mathrm{p}, \gamma)$ reaction rates increase ${ }^{35} \mathrm{Cl}$ abundances by factors of $\leq 5$ in $\mathrm{CO}$ nova models. The nucleosynthesis of ${ }^{37} \mathrm{Cl}$ is negligible and reaction rate variations have only insignificant effects. Note, that $\mathrm{CO}$ nova models produce much less ${ }^{35} \mathrm{Cl}$ compared to ONe nova models which are discussed below.

In ONe nova models JCH2, $\mathrm{P} 1$ and $\mathrm{P} 2$, the ${ }^{35} \mathrm{Cl}$ abundance changes by factors of $\leq 10$ as a result of varying the ${ }^{30} \mathrm{P}(\mathrm{p}, \gamma)$ and ${ }^{33} \mathrm{~S}(\mathrm{p}, \gamma)$ reaction rates. The ${ }^{35} \mathrm{Cl}$ abundance is also sensitive to ${ }^{34} \mathrm{~S}(\mathrm{p}, \gamma)$ reaction rate variations in models $\mathrm{JCH} 1, \mathrm{JCH} 2, \mathrm{P} 1$ and P2, resulting in abundance changes by factors of $\leq 20$. The abundance of ${ }^{37} \mathrm{Cl}$ changes in model P2 by factors of $\leq 24$ as a result of ${ }^{30} \mathrm{P}(\mathrm{p}, \gamma)$ and ${ }^{37} \mathrm{Ar}(\mathrm{p}, \gamma)$ reaction rate variations, while in model

S1 abundance changes of ${ }^{37} \mathrm{Cl}$ amount to factors of $\leq 38$ as a result of varying the ${ }^{37} \mathrm{Ar}(\mathrm{p}, \gamma)$ reaction rates. Most reaction rate variations tend to decrease the abundances of ${ }^{35} \mathrm{Cl}$ and ${ }^{37} \mathrm{Cl}$.

Therefore, the calculation of reliable chlorine abundances in the ejecta of ONe novae 
requires improved rates for several reactions.

\subsubsection{Argon Isotopes}

The nucleosynthesis of argon isotopes in CO nova models is negligible and reaction rate variations have only insignificant effects.

For ONe nova models $\mathrm{P} 1$ and $\mathrm{P} 2$, the ${ }^{36} \mathrm{Ar}$ abundance changes by factors of $\leq 7$ if the ${ }^{30} \mathrm{P}(\mathrm{p}, \gamma),{ }^{33} \mathrm{~S}(\mathrm{p}, \gamma)$ and ${ }^{34} \mathrm{~S}(\mathrm{p}, \gamma)$ reaction rates are varied within their errors. The ${ }^{37} \mathrm{Ar}$ abundance is sensitive to ${ }^{37} \mathrm{Ar}(\mathrm{p}, \gamma)$ reaction rate variations in all ONe nova models, and to ${ }^{30} \mathrm{P}(\mathrm{p}, \gamma)$ rate variations in model $\mathrm{P} 2$. Abundance changes amount to factors of $\leq 120$. The

${ }^{38} \mathrm{Ar}$ abundance is sensitive to ${ }^{37} \mathrm{Ar}(\mathrm{p}, \gamma)$ reaction rate variations in all models, to ${ }^{38} \mathrm{~K}(\mathrm{p}, \gamma)$ reaction rate variations in models $\mathrm{JCH} 2, \mathrm{P} 1, \mathrm{P} 2$ and $\mathrm{S} 1$, and to variations of ${ }^{30} \mathrm{P}(\mathrm{p}, \gamma)$ reaction rates in model $\mathrm{P} 2$. Changes in ${ }^{38} \mathrm{Ar}$ abundances amount to factors of $\leq 18$. As was the case for chlorine isotopes, most reaction rate variations tend to decrease the argon isotopic abundances.

In conclusion, several reaction rate uncertainties have to be reduced in order to predict reliable argon abundances in ONe nova ejecta.

\subsection{Comparison with Hydrodynamic Model Calculations}

In $\S 2$ we have pointed out that hydrodynamic nova model calculations are time consuming and, consequently, the effect of reaction rate variations on final isotopic abundances has been previously studied for only a few selected cases. In the following, we will compare some of our results with those obtained from previous hydrodynamic model calculations. It has to be kept in mind, as already discussed in detail, that our calculations 
neglect convection.

The dependence of ${ }^{18} \mathrm{~F}$ abundances on reaction rate variations has been studied by Coc et al. (2000). Their hydrodynamic model calculations were performed for ONe nova model JCH2 which has also been used for the one-zone calculations of the present work (Table 1). They quote factors of 10 and 310 for the ratio of maximum versus minimum ${ }^{18} \mathrm{~F}$ abundance as a consequence of ${ }^{17} \mathrm{O}+\mathrm{p}$ and ${ }^{18} \mathrm{~F}+\mathrm{p}$ reaction rate variations, respectively. Our result for ${ }^{18} \mathrm{~F}+\mathrm{p}$ reaction rate variations is in agreement with that of Coc et al. (2000), but for variations of ${ }^{17} \mathrm{O}+\mathrm{p}$ reaction rates we obtain larger ${ }^{18} \mathrm{~F}$ abundance changes. The agreement for ${ }^{18} \mathrm{~F}+\mathrm{p}$ and the disagreement for ${ }^{17} \mathrm{O}+\mathrm{p}$ could be explained by the fact that we use the same ${ }^{18} \mathrm{~F}+\mathrm{p}$ reaction rates and corresponding errors as Coc et al. (2000), while for ${ }^{17} \mathrm{O}+\mathrm{p}$ we use newer reaction rates which differ significantly from those adopted previously ( $\S 3.1$ and 3.3).

Abundance changes of ${ }^{22} \mathrm{Na}$ as a result of reaction rate variations have been studied by José et al. (1999). They performed hydrodynamic ONe nova model calculations assuming white dwarf masses of $1.15 \mathrm{M}_{\odot}$ and $1.25 \mathrm{M}_{\odot}$. The models are described in detail in José \& Hernanz (1998). They quote an increase in ${ }^{22} \mathrm{Na}$ abundance by a factor of $2-3$ as a result of reducing the ${ }^{21} \mathrm{Na}(\mathrm{p}, \gamma)$ reaction rates (adopted from Caughlan \& Fowler 1988) by a factor of 100. For ONe nova models JCH1 and JCH2, which are similar to those used in José et al. (1999), we also observe an increase of ${ }^{22} \mathrm{Na}$ abundance as a result of ${ }^{21} \mathrm{Na}(\mathrm{p}, \gamma)$ reaction rate decreases, although we find smaller effects in our one-zone calculations ( $\leq 50 \%$ decrease of abundance). The difference might be explained by the fact that some of the key reaction rates in this mass range adopted in José et al. (1999) and in the present work differ significantly.

Finally, the effects of ${ }^{30} \mathrm{P}(\mathrm{p}, \gamma)$ reaction rate variations on the synthesis of elements between Si and Ca has been investigated in José et al. (2001). They adopted a 
hydrodynamic ONe nova model with a white dwarf mass of $1.35 \mathrm{M}_{\odot}$, reaching a peak temperature of $\mathrm{T}_{\text {peak }}=0.331 \mathrm{GK}$. Details of the model can be found in José \& Hernanz (1998). They quote that the abundances of several isotopes $\left({ }^{31} \mathrm{P},{ }^{32} \mathrm{~S},{ }^{33} \mathrm{~S},{ }^{34} \mathrm{~S},{ }^{35} \mathrm{Cl}\right.$ and $\left.{ }^{36} \mathrm{Ar}\right)$

decrease by about an order of magnitude when the ${ }^{30} \mathrm{P}(\mathrm{p}, \gamma)$ reaction rates are decreased by a factor of 100 . They also find that only the ${ }^{30} \mathrm{Si}$ abundance changes by significant amounts if the ${ }^{30} \mathrm{P}(\mathrm{p}, \gamma)$ reaction rates are increased by a factor of 100 (Table 2 in José et al. 2001). Note, that the ONe nova models considered in the present work (Table 1) are different from the one adopted in José et al. (2001). Nevertheless, for ${ }^{30} \mathrm{P}(\mathrm{p}, \gamma)$ reaction rate variations we find qualitative and quantitative agreement with José et al. (2001) for all ONe nova models, as can be seen from Tables 5-11 (see also Fig. 3d).

\section{SUMMARY AND CONCLUSIONS}

In the present work, we have investigated the effects of thermonuclear reaction rate uncertainties on nova nucleosynthesis. One-zone nucleosynthesis calculations have been performed by adopting temperature-density-time profiles of the hottest hydrogen-burning zone from 7 different, recent hydrodynamic nova simulations (Politano et al. 1995; José \& Hernanz 1998; José, Coc, \& Hernanz 1999; Starrfield et al. 2002). The adopted nova models cover peak temperatures in the range of $\mathrm{T}_{\text {peak }}=0.145-0.418 \mathrm{GK}$ (Table 1 ). For each of these temperature-density-time profiles we have individually varied the rates of 175 reactions within their associated errors (Table 3) and analyzed the resulting abundance changes of 142 isotopes in the mass range below $A=40$. In total, we performed $\approx 7350$ reaction network calculations. We use the most recent thermonuclear reaction rate evaluations for the mass ranges $A=1-20$ (Angulo et al. 1999) and $A=20-40$ (Iliadis et al. 2001). Results are presented in tabular form for each adopted nova simulation (Tables 5-11). Figure 3 displays the results of reaction rate variations for a few selected cases. We find that present 
reaction rate estimates are reliable for predictions of $\mathrm{Li}, \mathrm{Be}, \mathrm{C}$ and $\mathrm{N}$ abundances in nova nucleosynthesis. However, uncertainties in the rates of several reactions have to be reduced significantly in order to predict more reliable $\mathrm{O}, \mathrm{F}, \mathrm{Ne}, \mathrm{Na}, \mathrm{Mg}, \mathrm{Al}, \mathrm{Si}, \mathrm{S}, \mathrm{Cl}$ and $\mathrm{Ar}$ abundances.

It is important to emphasize how to interpret the results of the present work. Hydrodynamic nova model calculations clearly show that typically only the outer layers of the envelope, not the deepest layers of the hydrogen-burning shell, are ejected after the thermonuclear runaway. The ejected layers are enriched, through convective mixing, with the products of the inner hydrogen-burning shell. From these considerations, it is clear that our calculations are unsuitable for defining absolute isotopic abundances resulting from nova nucleosynthesis, since our one-zone calculations necessarily ignore convection $(\S 2)$. Nevertheless, our procedure is adequate for exploring the effects of reaction rate uncertainties on abundance changes in the hottest hydrogen-burning zone, i.e., the region in which most of the nucleosythesis takes place. It follows, therefore, that our final abundances (Table 4) should neither be compared to elemental abundances observed in nova ejecta nor to results from hydrodynamic model calculations. We also would like to stress the following point. If a particular reaction rate variation has insignificant effects on isotopic abundances in our calculations, then it is most likely that a full hydrodynamic model calculation will yield a similar result. However, the reverse statement is not neccessarily correct, i.e., if we find significant abundance changes as a result of a particular reaction rate variation, then a full hydrodynamic model calculation might not produce significant effects. Clearly, our work does not represent the final answer to the question of which reactions should be targets for future measurements, but should be regarded as a first step in that direction.

In Table 12 we summarize qualitatively some of our results. The table lists isotopes whose abundances change by more than a factor of 2 in at least one of the nova models 
considered here as a result of varying a particular reaction rate within uncertainties. It is striking that for the vast majority of reactions included in our network calculations, reaction rate variations have an insignificant effect on final isotopic abundances in all nova models. Instead, final abundances are influenced by variations of a restricted number of key reaction rates. Closer inspection of Tables 5-11 also shows that variations of the same reaction rates in nova models of the same white dwarf mass (e.g., models P1 and JCH2 with $\mathrm{M}_{W D}=1.25 \mathrm{M}_{\odot} ;$ or models $\mathrm{P} 2$ and $\mathrm{S} 1$ with $\left.\mathrm{M}_{W D}=1.35 \mathrm{M}_{\odot}\right)$ yield quantitatively different changes in final abundances. This is not surprising since different nova models assume different initial envelope compositions (Table 2) and achieve different peak temperatures (Table 1).

It can be seen from Table 12 and from Figure 3 that reaction rate variations of a few reactions, such as ${ }^{23} \mathrm{Na}(\mathrm{p}, \gamma){ }^{24} \mathrm{Mg},{ }^{23} \mathrm{Mg}(\mathrm{p}, \gamma){ }^{24} \mathrm{Al},{ }^{30} \mathrm{P}(\mathrm{p}, \gamma){ }^{31} \mathrm{~S}$ and ${ }^{33} \mathrm{~S}(\mathrm{p}, \gamma){ }^{34} \mathrm{Cl}$, influence final abundances of a large number of isotopes. Consequently, new measurements of these reactions could significantly reduce uncertainties of isotopic abundances in nova model calculations. The reader might be surprised by the fact that certain reactions that were previously thought to play a role in nova nucleosynthesis do not appear in Table 12 . In agreement with previous work (Iliadis et al. 1999), we find insignificant isotopic abundance changes as a result of ${ }^{27} \mathrm{Si}(\mathrm{p}, \gamma){ }^{28} \mathrm{P},{ }^{31} \mathrm{~S}(\mathrm{p}, \gamma){ }^{33} \mathrm{Cl},{ }^{35} \mathrm{Ar}(\mathrm{p}, \gamma){ }^{36} \mathrm{~K}$ and ${ }^{39} \mathrm{Ca}(\mathrm{p}, \gamma){ }^{40} \mathrm{Sc}$ reaction rate variations for all nova models. This result has been confirmed by recent hydrodynamic model calculations (José et al. 2001). The ${ }^{15} \mathrm{O}(\alpha, \gamma){ }^{19} \mathrm{Ne}$ and ${ }^{19} \mathrm{Ne}(\mathrm{p}, \gamma){ }^{20} \mathrm{Na}$ reactions, which were thought to cause a breakout of material from the CNO mass region to the region beyond Ne, are also missing in Table 12. Rate variations for both reactions have only small effects on final abundances in all nova models, except in model S1 which achieves the highest peak temperature $\left(\mathrm{T}_{\text {peak }}=0.418 \mathrm{GK}\right)$. According to Table 7 , an increase of those two reaction rates by a factor of 100 has only a moderate influence on abundance changes in the mass range below $A=20$. But even for this rather high peak temperature, 
no breakout of material from the CNO mass region is observed. This result has also been confirmed by recent hydrodynamic model calculations (Starrfield et al. 2002). It is also apparent from Tables $5-11$ that $(\alpha, \gamma)$ and $(\alpha, \mathrm{p})$ reactions in general are not important for nova nucleosynthesis.

Finally, it should be noted that it is difficult to estimate reliable reaction rate errors in certain cases. Consider as an example the ${ }^{25} \mathrm{Al}(\mathrm{p}, \gamma){ }^{26} \mathrm{Si}$ reaction. In this case, as for most other reactions involving short-lived target nuclei, we have assumed a reaction rate error of a factor of 100 up and down ( $\S 3.3$ and Table 3$)$. An inspection of Tables 5-11 reveals only small abundance changes (within a factor of 2) as a result of varying the corresponding reaction rates within a factor of 100 . However, for this particular case we have only limited experimental information regarding the energies of unobserved low-energy resonances (Iliadis et al. 1996). Depending on the location of these resonances, the ${ }^{25} \mathrm{Al}(\mathrm{p}, \gamma){ }^{26} \mathrm{Si}$ reaction rates could increase by much more than 2 orders of magnitude. As a consequence, the ${ }^{26} \mathrm{Al}$ abundance will decrease significantly in all ONe nova models. Although not listed in Table 12, it is clear from this discussion that measurements of reactions such as ${ }^{25} \mathrm{Al}(\mathrm{p}, \gamma){ }^{26} \mathrm{Si}$ are also desirable in order to improve predictions of nova nucleosynthesis.

The authors would like to thank A. Coc, M. Hernanz, R. Hix and M. Smith for stimulating discussions. We are also grateful for the detailed review of this work by the referee, S. Shore. This work was supported in part by the U. S. Department of Energy under Grant No. DE-FG02-97ER41041, by CICYT-PNIE ESP98-1348 and DGES PB98-1183-C03-02, and by Grants from NASA and NSF to ASU. 


\section{REFERENCES}

Amari, S., Gao, X., Nittler, L., Zinner, E., José, J., Hernanz, M., \& Lewis, R.S. 2001, ApJ, 551,1065

Angulo, C., et al. 1999, Nucl. Phys. A, 656, 3

Arnett, W.D., \& Truran, J.W. 1969, ApJ, 157, 339

Arnould, M., \& Norgaard, H. 1975, A\&A, 42, 55

Audi, G., Bersillon, O., Blachot, J., \& Wapstra, A.H. 1997, Nucl. Phys. A, 624, 1

Bahcall, J.N., Huebner, W.F., Lubow, S.H., Parker, P.D., \& Ulrich, R.K. 1982, Rev. Mod. Phys., 54, 767

Bardayan, D.W., et al. 2000, Phys. Rev. C, 62, 055804

Beaumel, D., et al. 2001, Phys. Lett. B, 514, 226

Blackmon, J., et al. 2001, in preparation

Caughlan, G. R., \& Fowler, W.A., 1988, At. Data Nucl. Data Tables, 40, 283

Clayton, D.D., \& Hoyle, F. 1974, ApJ, 187, L101

Coc, A., Hernanz, M., José, J., \& Thibaud, J.-P. 2000, A\&A, 357, 561

Diehl, R., et al. 1995, A\&A, 298, 445

Diehl, R. 1997, in AIP Conf. Proc. 410, Proceedings of the Fourth Compton Symposium, ed. C.D. Dermer, M.S. Strickman, \& J.D. Kurfess (New York: AIP), 1114

Gehrz, R.D., Truran, J.W., Williams, R.E., \& Starrfield, S. 1998, PASP, 110, 3

Gómez-Gomar, J., Hernanz, M., José, J., \& Isern, J. 1998, MNRAS, 296, 913 
Hernanz, M., José, J., Coc, A., \& Isern, J. 1996, ApJ, 465, L27

Hernanz, M., José, J., Coc, A., Gómez-Gomar, J., \& Isern, J. 1999, ApJ, 526, L97

Hix, W.R., Smith, M.S., Mezzacappa, A., Starrfield, S., \& Smith, D.L. 2002, Proceedings of the 2nd Chicago Conference on Astrophysical Explosions, eds. E. Brown, J. Niemeyer, R. Rosner and J. Truran, University of Chicago Press

Hoffman, R.D., Woosley, S.E., Weaver, T.A., Rauscher, T., \& Thielemann, F.-K. 1999, ApJ, 521, 735

Hoffman, R.D., Woosley, S.E., \& Weaver, T.A. 2001, ApJ, 549, 1085

Iliadis, C., Buchmann, L., Endt, P.M., Herndl, H., \& Wiescher, M. 1996, Phys. Rev. C, 53, 475

Iliadis, C., Endt, P.M., Prantzos, N., \& Thompson, W.J. 1999, ApJ, 524434

Iliadis, C., D'Auria, J.M., Starrfield, S., Thompson, W.J., \& Wiescher, M. 2001, ApJS, 134, 151

José, J., Hernanz, M., \& Coc, A. 1997, ApJ, 479, L55

José, J., \& Hernanz, M. 1998, ApJ, 494, 680

José, J., Coc, A., \& Hernanz, M. 1999, ApJ, 520, 347

José, J., Coc, A., \& Hernanz, M. 2001, ApJ, 560, 897

Knödlseder, J. 1999, ApJ, 510, 915

Kovetz, A., \& Prialnik, D. 1997, ApJ, 477, 356

Lazareff, B., Audouze, J., Starrfield, S., \& Truran, J.W. 1979, ApJ, 228, 875 
Leising, M., \& Clayton, D.D. 1987, ApJ, 323, 159

Mahoney, W.A., Ling, J.C., Jacobson, A.S., \& Lingenfelter, R.E. 1982, ApJ, 262, 742

Politano, M., Starrfield, S., Truran, J. W., Weiss, A., \& Sparks, W. M. 1995, ApJ, 448, 807

Prantzos, N., \& Diehl, R. 1996, Phys. Rep., 267, 1

Rauscher, T., \& Thielemann, F.-K. 2000, At. Data Nucl. Data Tables, 75, 1

Ritossa, C., García-Berro, E., \& Iben, I. 1996, ApJ, 460, 489

Romano, D., Matteucci, F., Molaro, P., \& Bonifacio, P. 1999, A\&A, 352, 117

Runkle, R.C., Champagne, A.E., \& Engel, J. 2001, ApJ, 556, 970

Starrfield, S., Truran, J.W., Sparks, W.M., \& Kutter, G.S. 1972, ApJ, 176, 169

Starrfield, S., Truran, J.W., Sparks, W.M., \& Arnould, M. 1978, ApJ, 222, 600

Starrfield, S., Truran, J.W., Wiescher, M.C., \& Sparks, W.M. 1998, MNRAS, 296, 502

Starrfield, S., Sparks, W.M., Truran, J.W., \& Wiescher, M.C. 2000, ApJS, 127, 485

Starrfield, S., et al. 2002, ApJS, in preparation

The, L.-S., Clayton, D.D., Jin, L., \& Meyer, B.S. 1998, ApJ, 504, 500

Ward, R.A., \& Fowler, W.A. 1980, ApJ, 238, 266

Wiescher, M., Görres, J., Graff, S., Buchmann, L., \& Thielemann, F.K. 1989, ApJ, 343, 352 
Fig. 1.- Temperature-density profiles for the hottest hydrogen-burning zone of CO novae (dashed lines) and ONe novae (solid lines). The nuclear-burning conditions evolve in time from larger to smaller densities. The profiles have been adopted from recently published hydrodynamic nova simulations and are described in more detail in Table 1 . The very small ripples visible in some profiles near peak temperature originate from numerical instabilities which are not important for present considerations.

Fig. 2.- Initial envelope composition (in mass fractions) for nova nucleosynthesis calculations. (a) ONe models P1, P2, S1. (b) ONe models JCH1, JCH2. (c) CO model JH1. (d) CO model JH2. For more details, see Table 2.

Fig. 3.- Factor change, $\mathrm{X}_{i} / \mathrm{X}_{i, \text { rec }}$, in final isotopic abundance as a result of varying a specific reaction rate within the assigned errors (as given in Table 3) vs. mass number. The diamonds and triangles correspond to the upper and lower limit of the reaction rate, respectively. (a) Variation of ${ }^{21} \mathrm{Na}(\mathrm{p}, \gamma)^{22} \mathrm{Mg}$ reaction rate in ONe model P2. (b) Variation of ${ }^{23} \mathrm{Na}(\mathrm{p}, \gamma){ }^{24} \mathrm{Mg}$ reaction rate in ONe model JCH1. (c) Variation of ${ }^{23} \mathrm{Mg}(\mathrm{p}, \gamma){ }^{24} \mathrm{Al}$ reaction rate in ONe model S1. (d) Variation of ${ }^{30} \mathrm{P}(\mathrm{p}, \gamma){ }^{31} \mathrm{~S}$ reaction rate in ONe model JCH2. (e) Variation of ${ }^{33} \mathrm{~S}(\mathrm{p}, \gamma){ }^{34} \mathrm{Cl}$ reaction rate in ONe model $\mathrm{P} 1$. The symbols for ${ }^{22} \mathrm{Na},{ }^{26} \mathrm{Al}$ and ${ }^{37} \mathrm{Ar}$ have been shifted slightly to the right for clarity. 
Table 1. PROPERTIES OF RECENT EVOLUTIONARY NOVA MODELS a

\begin{tabular}{|c|c|c|c|c|c|c|c|}
\hline MODEL & $\mathrm{P} 1$ & P2 & S1 & $\mathrm{JCH} 1$ & $\mathrm{JCH} 2$ & JH1 & $\mathrm{JH} 2$ \\
\hline WD MASS $\left(\mathrm{M}_{\odot}\right)$ & 1.25 & 1.35 & 1.35 & 1.15 & 1.25 & 0.8 & 1.0 \\
\hline WD COMPOSITION & ONe & ONe & $\mathrm{ONe}$ & ONe & $\mathrm{ONe}$ & $\mathrm{CO}$ & $\mathrm{CO}$ \\
\hline MIXING $(\%)^{\mathrm{b}}$ & 50 & 50 & 50 & 50 & 50 & 25 & 50 \\
\hline $\mathrm{T}_{\text {peak }}\left(10^{6} \mathrm{~K}\right)$ & 290 & 356 & 418 & 231 & 251 & 145 & 170 \\
\hline $\mathrm{L}_{\text {peak }}\left(10^{4} \mathrm{~L}_{\odot}\right)$ & 4.3 & 16.3 & 39 & 26 & 46 & 3.5 & 23 \\
\hline $\mathrm{M}_{a c c}\left(10^{-5} \mathrm{M}_{\odot}\right)$ & 3.2 & 1.5 & 3.8 & 3.2 & 2.2 & 9.7 & 3.9 \\
\hline$\dot{\mathrm{M}}_{a c c}\left(10^{-10} \mathrm{M}_{\odot} / \mathrm{yr}\right)$ & 16 & 16 & 1.6 & 2.0 & 2.0 & 2.0 & 2.0 \\
\hline $\mathrm{M}_{e j}\left(10^{-5} \mathrm{M}_{\odot}\right)$ & 0.0 & 0.62 & 2.2 & 2.6 & 1.8 & 7.0 & 2.3 \\
\hline
\end{tabular}

a Models labeled "P", "S", "JCH" and "JH" are adopted from Politano et al. (1995), Starrfield et al. (2002), José, Coc, \& Hernanz (1999) and José \& Hernanz (1998), respectively.

${ }^{\mathrm{b}}$ Percentage of mixing assumed between solar accreted matter with white dwarf core material. The initial envelope composition is given in Table 2 . 
Table 2. INITIAL ENVELOPE COMPOSITION (MASS FRACTIONS) OF RECENT NOVA SIMULATIONS

\begin{tabular}{|c|c|c|c|c|}
\hline \multirow[t]{2}{*}{ NUCLEUS } & \multicolumn{4}{|c|}{ MODEL $^{a}$} \\
\hline & $\mathrm{P} 1, \mathrm{P} 2, \mathrm{~S} 1 \mathrm{~b}$ & $\mathrm{JCH} 1, \mathrm{JCH} 2^{\mathrm{c}}$ & $\mathrm{JH} 1^{\mathrm{d}}$ & $\mathrm{JH} 2{ }^{\mathrm{e}}$ \\
\hline${ }^{1} \mathrm{H}$ & 3.7E-01 & $3.5 \mathrm{E}-01$ & $5.3 \mathrm{E}-01$ & $3.5 \mathrm{E}-01$ \\
\hline${ }^{2} \mathrm{H}$ & $0.0 \mathrm{E}+00$ & $2.4 \mathrm{E}-05$ & $3.6 \mathrm{E}-05$ & $2.4 \mathrm{E}-05$ \\
\hline${ }^{3} \mathrm{He}$ & $5.8 \mathrm{E}-06$ & $1.5 \mathrm{E}-05$ & $2.2 \mathrm{E}-05$ & $1.5 \mathrm{E}-05$ \\
\hline${ }^{4} \mathrm{He}$ & $1.3 \mathrm{E}-01$ & $1.4 \mathrm{E}-01$ & $2.1 \mathrm{E}-01$ & $1.4 \mathrm{E}-01$ \\
\hline${ }^{6} \mathrm{Li}$ & $0.0 \mathrm{E}+00$ & $3.2 \mathrm{E}-10$ & $4.9 \mathrm{E}-10$ & $3.3 \mathrm{E}-10$ \\
\hline${ }^{7} \mathrm{Li}$ & $0.0 \mathrm{E}+00$ & 4.7E-09 & 7.0E-09 & 4.7E-09 \\
\hline${ }^{9} \mathrm{Be}$ & $0.0 \mathrm{E}+00$ & $8.3 \mathrm{E}-11$ & $1.2 \mathrm{E}-10$ & $8.3 \mathrm{E}-11$ \\
\hline${ }^{10} \mathrm{~B}$ & $0.0 \mathrm{E}+00$ & $5.3 \mathrm{E}-10$ & $8.0 \mathrm{E}-10$ & $5.4 \mathrm{E}-10$ \\
\hline${ }^{11} \mathrm{~B}$ & $0.0 \mathrm{E}+00$ & $2.4 \mathrm{E}-09$ & 3.6E-09 & $2.4 \mathrm{E}-09$ \\
\hline${ }^{12} \mathrm{C}$ & $9.4 \mathrm{E}-04$ & $6.1 \mathrm{E}-03$ & $1.3 \mathrm{E}-01$ & $2.5 \mathrm{E}-01$ \\
\hline${ }^{13} \mathrm{C}$ & $1.2 \mathrm{E}-05$ & $1.8 \mathrm{E}-05$ & $2.7 \mathrm{E}-05$ & $1.8 \mathrm{E}-05$ \\
\hline${ }^{14} \mathrm{~N}$ & $2.3 \mathrm{E}-06$ & $5.5 \mathrm{E}-04$ & 8.3E-04 & $5.6 \mathrm{E}-04$ \\
\hline${ }^{15} \mathrm{~N}$ & $9.1 \mathrm{E}-07$ & $2.2 \mathrm{E}-06$ & $3.3 \mathrm{E}-06$ & $2.2 \mathrm{E}-06$ \\
\hline${ }^{16} \mathrm{O}$ & $1.5 \mathrm{E}-01$ & $2.6 \mathrm{E}-01$ & $1.3 \mathrm{E}-01$ & $2.5 \mathrm{E}-01$ \\
\hline${ }^{17} \mathrm{O}$ & $8.5 \mathrm{E}-07$ & $1.9 \mathrm{E}-06$ & $2.9 \mathrm{E}-06$ & $2.0 \mathrm{E}-06$ \\
\hline${ }^{18} \mathrm{O}$ & $4.9 \mathrm{E}-06$ & $1.1 \mathrm{E}-05$ & $1.6 \mathrm{E}-05$ & $1.1 \mathrm{E}-05$ \\
\hline${ }^{19} \mathrm{~F}$ & $1.1 \mathrm{E}-07$ & $2.0 \mathrm{E}-07$ & $3.0 \mathrm{E}-07$ & $2.0 \mathrm{E}-07$ \\
\hline${ }^{20} \mathrm{Ne}$ & $2.5 \mathrm{E}-01$ & $1.6 \mathrm{E}-01$ & $1.2 \mathrm{E}-03$ & $8.1 \mathrm{E}-04$ \\
\hline${ }^{21} \mathrm{Ne}$ & $9.0 \mathrm{E}-07$ & $3.0 \mathrm{E}-03$ & $3.1 \mathrm{E}-06$ & $2.1 \mathrm{E}-06$ \\
\hline${ }^{22} \mathrm{Ne}$ & $2.8 \mathrm{E}-05$ & $2.2 \mathrm{E}-03$ & $2.6 \mathrm{E}-03$ & $5.1 \mathrm{E}-03$ \\
\hline${ }^{23} \mathrm{Na}$ & $9.2 \mathrm{E}-06$ & $3.2 \mathrm{E}-02$ & $2.5 \mathrm{E}-05$ & $1.7 \mathrm{E}-05$ \\
\hline${ }^{24} \mathrm{Mg}$ & $1.0 \mathrm{E}-01$ & $2.8 \mathrm{E}-02$ & $3.9 \mathrm{E}-04$ & $2.6 \mathrm{E}-04$ \\
\hline${ }^{25} \mathrm{Mg}$ & $1.9 \mathrm{E}-05$ & $7.9 \mathrm{E}-03$ & $5.1 \mathrm{E}-05$ & $3.4 \mathrm{E}-05$ \\
\hline${ }^{26} \mathrm{Mg}$ & $2.2 \mathrm{E}-05$ & $5.0 \mathrm{E}-03$ & $5.8 \mathrm{E}-05$ & $3.9 \mathrm{E}-05$ \\
\hline${ }^{27} \mathrm{Al}$ & $1.6 \mathrm{E}-05$ & $5.4 \mathrm{E}-03$ & $4.3 \mathrm{E}-05$ & $2.9 \mathrm{E}-05$ \\
\hline${ }^{28} \mathrm{Si}$ & $1.8 \mathrm{E}-04$ & $3.3 \mathrm{E}-04$ & $4.9 \mathrm{E}-04$ & $3.3 \mathrm{E}-04$ \\
\hline${ }^{29} \mathrm{Si}$ & $9.5 \mathrm{E}-06$ & $1.7 \mathrm{E}-05$ & $2.6 \mathrm{E}-05$ & $1.7 \mathrm{E}-05$ \\
\hline${ }^{30} \mathrm{Si}$ & $6.5 \mathrm{E}-06$ & $1.2 \mathrm{E}-05$ & $1.8 \mathrm{E}-05$ & $1.2 \mathrm{E}-05$ \\
\hline${ }^{31} \mathrm{P}$ & $2.3 \mathrm{E}-06$ & $1.1 \mathrm{E}-06$ & $6.1 \mathrm{E}-06$ & 4.1E-06 \\
\hline${ }^{32} \mathrm{~S}$ & $1.1 \mathrm{E}-04$ & $2.0 \mathrm{E}-04$ & 3.0E-04 & $2.0 \mathrm{E}-04$ \\
\hline${ }^{33} \mathrm{~S}$ & $9.0 \mathrm{E}-07$ & $4.5 \mathrm{E}-07$ & $2.4 \mathrm{E}-06$ & $1.6 \mathrm{E}-06$ \\
\hline${ }^{34} \mathrm{~S}$ & $5.2 \mathrm{E}-06$ & $2.6 \mathrm{E}-06$ & $1.4 \mathrm{E}-05$ & $9.3 \mathrm{E}-06$ \\
\hline${ }^{35} \mathrm{Cl}$ & $9.8 \mathrm{E}-07$ & $4.9 \mathrm{E}-07$ & $1.9 \mathrm{E}-06$ & $1.3 \mathrm{E}-06$ \\
\hline${ }^{37} \mathrm{Cl}$ & $3.3 \mathrm{E}-07$ & $1.7 \mathrm{E}-07$ & $6.4 \mathrm{E}-07$ & 4.3E-07 \\
\hline${ }^{36} \mathrm{Ar}$ & $1.9 \mathrm{E}-05$ & $3.9 \mathrm{E}-05$ & $5.8 \mathrm{E}-05$ & $3.9 \mathrm{E}-05$ \\
\hline${ }^{38} \mathrm{Ar}$ & $3.8 \mathrm{E}-06$ & $1.9 \mathrm{E}-06$ & $1.2 \mathrm{E}-05$ & $7.7 \mathrm{E}-06$ \\
\hline${ }^{39} \mathrm{~K}$ & $9.6 \mathrm{E}-07$ & $4.8 \mathrm{E}-07$ & $2.6 \mathrm{E}-06$ & $1.7 \mathrm{E}-06$ \\
\hline${ }^{40} \mathrm{Ca}$ & $1.7 \mathrm{E}-05$ & $3.0 \mathrm{E}-05$ & $4.5 \mathrm{E}-05$ & $3.0 \mathrm{E}-05$ \\
\hline
\end{tabular}

${ }^{\text {a }}$ Model properties are summarized in Table 1.

${ }^{\mathrm{b}}$ From Politano et al. (1995); values are derived from carbon-burning nucleosynthesis studies of Arnett \& Truran (1969), assuming 50\% mixing of solar accreted matter with white dwarf core material.

${ }^{c}$ From José, Coc, \& Hernanz (1999); values are derived from carbon-burning nucleosynthesis studies of Ritossa et al. (1996), assuming 50\% mixing of solar accreted matter with white dwarf core material.

d From José \& Hernanz (1998); values are obtained assuming 25\% mixing of solar accreted matter with white dwarf core material.

${ }^{\text {e}}$ From José \& Hernanz (1998); values are obtained assuming 50\% mixing of solar accreted matter with white dwarf core material. 
Table 3. UNCERTAINTIES OF SELECTED REACTION RATES AT NOVA

TEMPERATURES ${ }^{a}$

\begin{tabular}{|c|c|c|c|}
\hline Reaction & $\begin{array}{c}\text { Factor } \\
\text { Up/Down }\end{array}$ & Reaction & $\begin{array}{c}\text { Factor } \\
\text { Up/Down }\end{array}$ \\
\hline${ }^{3} \mathrm{He}(\alpha, \gamma)^{7} \mathrm{Be}$ & $1.20 / 0.83$ & ${ }^{26} \mathrm{Mg}(\mathrm{p}, \gamma){ }^{27} \mathrm{Al}$ & $4.0 / 0.70$ \\
\hline${ }^{7} \mathrm{Be}(\mathrm{p}, \gamma)^{8} \mathrm{~B}$ & $1.12 / 0.89$ & ${ }^{25} \mathrm{Al}(\mathrm{p}, \gamma)^{26} \mathrm{Si}$ & $100 / 0.01$ \\
\hline${ }^{7} \mathrm{Be}(\alpha, \gamma){ }^{11} \mathrm{C}$ & $1.40 / 0.71$ & ${ }^{26} \mathrm{Al}^{g}(\mathrm{p}, \gamma)^{27} \mathrm{Si}$ & $10 / 0.80$ \\
\hline${ }^{8} \mathrm{~B}(\mathrm{p}, \gamma){ }^{9} \mathrm{C}$ & $10 / 0.1$ & ${ }^{26} \mathrm{Al}^{m}(\mathrm{p}, \gamma)^{27} \mathrm{Si}$ & $100 / 0.01$ \\
\hline${ }^{12} \mathrm{C}(\mathrm{p}, \gamma)^{13} \mathrm{~N}$ & $1.12 / 0.89$ & ${ }^{27} \mathrm{Al}(\mathrm{p}, \gamma)^{28} \mathrm{Si}$ & $1.25 / 0.80$ \\
\hline${ }^{13} \mathrm{C}(\mathrm{p}, \gamma)^{14} \mathrm{~N}$ & $1.20 / 0.83$ & ${ }^{27} \mathrm{Al}(\mathrm{p}, \alpha){ }^{24} \mathrm{Mg}$ & $10 / 10^{-3}$ \\
\hline${ }^{13} \mathrm{~N}(\mathrm{p}, \gamma)^{14} \mathrm{O}$ & $1.50 / 0.67$ & ${ }^{27} \mathrm{Si}(\mathrm{p}, \gamma){ }^{28} \mathrm{P}$ & $10 / 0.1$ \\
\hline${ }^{14} \mathrm{~N}(\mathrm{p}, \gamma)^{15} \mathrm{O}$ & $1.30 / 0.77$ & ${ }^{28} \mathrm{Si}(\mathrm{p}, \gamma){ }^{29} \mathrm{P}$ & $1.70 / 0.58$ \\
\hline${ }^{15} \mathrm{~N}(\mathrm{p}, \gamma)^{16} \mathrm{O}$ & $1.50 / 0.67$ & ${ }^{29} \mathrm{Si}(\mathrm{p}, \gamma){ }^{30} \mathrm{P}$ & $10 / 0.1$ \\
\hline${ }^{15} \mathrm{~N}(\mathrm{p}, \alpha){ }^{12} \mathrm{C}$ & $1.40 / 0.71$ & ${ }^{30} \mathrm{Si}(\mathrm{p}, \gamma){ }^{31} \mathrm{P}$ & $10 / 0.1$ \\
\hline${ }^{15} \mathrm{O}(\alpha, \gamma){ }^{19} \mathrm{Ne}$ & $100 / 0.01$ & ${ }^{29} \mathrm{P}(\mathrm{p}, \gamma){ }^{30} \mathrm{~S}$ & $100 / 0.01$ \\
\hline${ }^{16} \mathrm{O}(\mathrm{p}, \gamma)^{17} \mathrm{~F}$ & $1.40 / 0.71$ & ${ }^{30} \mathrm{P}(\mathrm{p}, \gamma)^{31} \mathrm{~S}^{\mathrm{e}}$ & $100 / 0.01$ \\
\hline${ }^{17} \mathrm{O}(\mathrm{p}, \gamma)^{18} \mathrm{~F}^{\mathrm{b}}$ & $10 / 0.1$ & ${ }^{31} \mathrm{P}(\mathrm{p}, \gamma){ }^{32} \mathrm{~S}$ & $1.25 / 0.80$ \\
\hline${ }^{17} \mathrm{O}(\mathrm{p}, \alpha)^{14} \mathrm{~N}^{\mathrm{b}}$ & $10 / 0.1$ & ${ }^{31} \mathrm{P}(\mathrm{p}, \alpha){ }^{28} \mathrm{Si}$ & $7.0 / 0.30$ \\
\hline${ }^{18} \mathrm{O}(\mathrm{p}, \gamma){ }^{19} \mathrm{~F}$ & $1.10 / 0.91$ & ${ }^{31} \mathrm{~S}(\mathrm{p}, \gamma){ }^{32} \mathrm{Cl}$ & $10 / 0.1$ \\
\hline${ }^{17} \mathrm{~F}(\mathrm{p}, \gamma)^{18} \mathrm{Ne}^{\mathrm{c}}$ & $10 / 0.1$ & ${ }^{32} \mathrm{~S}(\mathrm{p}, \gamma)^{33} \mathrm{Cl}$ & $1.40 / 0.71$ \\
\hline${ }^{18} \mathrm{~F}(\mathrm{p}, \gamma)^{19} \mathrm{Ne}^{\mathrm{d}}$ & $15 / 0.066$ & ${ }^{33} \mathrm{~S}(\mathrm{p}, \gamma)^{34} \mathrm{Cl} \mathrm{e}^{\mathrm{j}}$ & $100 / 0.01$ \\
\hline${ }^{18} \mathrm{~F}(\mathrm{p}, \alpha)^{15} \mathrm{O}^{\mathrm{d}}$ & $30 / 0.033$ & ${ }^{34} \mathrm{~S}(\mathrm{p}, \gamma)^{35} \mathrm{Cl}$ e & $100 / 0.01$ \\
\hline${ }^{19} \mathrm{~F}(\mathrm{p}, \alpha){ }^{16} \mathrm{O}$ & $1.40 / 0.71$ & ${ }^{33} \mathrm{Cl}(\mathrm{p}, \gamma)^{34} \mathrm{Ar}$ & $100 / 0.01$ \\
\hline${ }^{19} \mathrm{Ne}(\mathrm{p}, \gamma)^{20} \mathrm{Na}$ & $100 / 0.01$ & ${ }^{34} \mathrm{Cl}(\mathrm{p}, \gamma){ }^{35} \mathrm{Ar}$ & $100 / 0.01$ \\
\hline${ }^{20} \mathrm{Ne}(\mathrm{p}, \gamma)^{21} \mathrm{Na}$ & $1.70 / 0.58$ & ${ }^{35} \mathrm{Cl}(\mathrm{p}, \gamma)^{36} \mathrm{Ar}$ & $1.73 / 0.58$ \\
\hline${ }^{21} \mathrm{Ne}(\mathrm{p}, \gamma)^{22} \mathrm{Na}$ & $1.25 / 0.80$ & ${ }^{35} \mathrm{Cl}(\mathrm{p}, \alpha)^{32} \mathrm{~S}$ & $10 / 10^{-7}$ \\
\hline${ }^{22} \mathrm{Ne}(\mathrm{p}, \gamma)^{23} \mathrm{Na}$ & $1000 / 0.30$ & ${ }^{35} \operatorname{Ar}(\mathrm{p}, \gamma)^{36} \mathrm{~K}$ & $10 / 0.1$ \\
\hline${ }^{21} \mathrm{Na}(\mathrm{p}, \gamma)^{22} \mathrm{Mg}$ & $100 / 0.01$ & ${ }^{36} \operatorname{Ar}(\mathrm{p}, \gamma){ }^{37} \mathrm{~K}$ & $1.15 / 0.87$ \\
\hline${ }^{22} \mathrm{Na}(\mathrm{p}, \gamma)^{23} \mathrm{Mg}$ & $2.8 / 0.35$ & ${ }^{37} \operatorname{Ar}(\mathrm{p}, \gamma){ }^{38} \mathrm{~K}^{\mathrm{e}}$ & $100 / 0.01$ \\
\hline${ }^{23} \mathrm{Na}(\mathrm{p}, \gamma)^{24} \mathrm{Mg}$ & $10 / 0.01$ & ${ }^{38} \mathrm{Ar}(\mathrm{p}, \gamma){ }^{39} \mathrm{~K}^{\mathrm{e}}$ & $100 / 0.01$ \\
\hline${ }^{23} \mathrm{Na}(\mathrm{p}, \alpha)^{20} \mathrm{Ne}$ & $1.40 / 0.71$ & ${ }^{37} \mathrm{~K}(\mathrm{p}, \gamma)^{38} \mathrm{Ca}{ }^{\mathrm{e}}$ & $100 / 0.01$ \\
\hline${ }^{23} \mathrm{Mg}(\mathrm{p}, \gamma)^{24} \mathrm{Al}$ & $100 / 0.01$ & ${ }^{38} \mathrm{~K}(\mathrm{p}, \gamma)^{39} \mathrm{Ca}{ }^{\mathrm{e}}$ & $100 / 0.01$ \\
\hline${ }^{24} \mathrm{Mg}(\mathrm{p}, \gamma)^{25} \mathrm{Al}$ & $1.15 / 0.87$ & ${ }^{39} \mathrm{~K}(\mathrm{p}, \gamma)^{40} \mathrm{Ca}{ }^{\mathrm{e}}$ & $100 / 0.01$ \\
\hline${ }^{25} \mathrm{Mg}(\mathrm{p}, \gamma)^{26} \mathrm{Al}^{g}$ & $1.70 / 0.58$ & ${ }^{39} \mathrm{Ca}(\mathrm{p}, \gamma)^{40} \mathrm{Sc}$ & $10 / 0.1$ \\
\hline${ }^{25} \mathrm{Mg}(\mathrm{p}, \gamma)^{26} \mathrm{Al}^{m}$ & $1.70 / 0.58$ & ${ }^{40} \mathrm{Ca}(\mathrm{p}, \gamma){ }^{41} \mathrm{Sc}$ & $1.35 / 0.74$ \\
\hline
\end{tabular}

${ }^{a}$ Reaction rate errors are extracted from Angulo et al. (1999) and Iliadis et al. (2001), unless noted otherwise; for reaction rate errors that vary significantly with temperature, we list the maximum reaction rate error in the temperature range of relevance to nova nucleosynthesis $(\mathrm{T}=0.1-0.4$ GK).

${ }^{\mathrm{b}}$ From Blackmon et al. (2001).

${ }^{\mathrm{c}}$ Bardayan et al. (2000) quote an uncertainty of only $15 \%$ (see text).

${ }^{\mathrm{d}}$ From Coc et al. (2000).

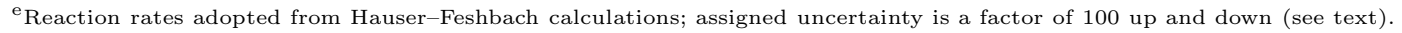


Table 4. FINAL ABUNDANCES (MASS FRACTIONS) FROM PRESENT ONE-ZONE NOVA NUCLEOSYNTHESIS CALCULATIONS ${ }^{a}$

\begin{tabular}{|c|c|c|c|c|c|c|c|}
\hline \multirow[t]{2}{*}{ NUCLEUS } & \multicolumn{7}{|c|}{ MODEL b } \\
\hline & $\mathrm{P} 1$ & $\mathrm{P} 2$ & $\mathrm{~S} 1$ & $\mathrm{JCH} 1$ & $\mathrm{JCH} 2$ & JH1 & $\mathrm{JH} 2$ \\
\hline${ }^{1} \mathrm{H}$ & $2.6 \mathrm{E}-01$ & $2.0 \mathrm{E}-01$ & $1.5 \mathrm{E}-01$ & $1.6 \mathrm{E}-01$ & $1.5 \mathrm{E}-01$ & $4.6 \mathrm{E}-01$ & $2.4 \mathrm{E}-01$ \\
\hline${ }^{3} \mathrm{He}$ & $0.0 \mathrm{E}+00$ & $0.0 \mathrm{E}+00$ & $0.0 \mathrm{E}+00$ & $0.0 \mathrm{E}+00$ & $0.0 \mathrm{E}+00$ & $3.6 \mathrm{E}-07$ & $4.5 \mathrm{E}-07$ \\
\hline${ }^{4} \mathrm{He}$ & $2.1 \mathrm{E}-01$ & $2.2 \mathrm{E}-01$ & $2.2 \mathrm{E}-01$ & $3.6 \mathrm{E}-01$ & $3.6 \mathrm{E}-01$ & $2.6 \mathrm{E}-01$ & $2.2 \mathrm{E}-01$ \\
\hline${ }^{7} \mathrm{Be}$ & $6.0 \mathrm{E}-08$ & $7.2 \mathrm{E}-07$ & $2.3 \mathrm{E}-07$ & $1.9 \mathrm{E}-10$ & $1.8 \mathrm{E}-08$ & 8.7E-09 & $5.9 \mathrm{E}-07$ \\
\hline${ }^{12} \mathrm{C}$ & $2.1 \mathrm{E}-02$ & $5.1 \mathrm{E}-02$ & $4.3 \mathrm{E}-02$ & $3.5 \mathrm{E}-02$ & $6.2 \mathrm{E}-02$ & $8.4 \mathrm{E}-03$ & $2.6 \mathrm{E}-02$ \\
\hline${ }^{13} \mathrm{C}$ & $2.3 \mathrm{E}-02$ & $2.7 \mathrm{E}-02$ & $1.9 \mathrm{E}-02$ & $6.6 \mathrm{E}-02$ & $6.9 \mathrm{E}-02$ & $9.7 \mathrm{E}-03$ & $6.9 \mathrm{E}-02$ \\
\hline${ }^{14} \mathrm{~N}$ & $6.1 \mathrm{E}-02$ & $2.2 \mathrm{E}-02$ & $2.2 \mathrm{E}-02$ & $1.2 \mathrm{E}-01$ & $8.1 \mathrm{E}-02$ & $1.5 \mathrm{E}-01$ & $2.2 \mathrm{E}-01$ \\
\hline${ }^{15} \mathrm{~N}$ & $3.2 \mathrm{E}-06$ & $8.2 \mathrm{E}-03$ & $4.2 \mathrm{E}-02$ & $2.5 \mathrm{E}-05$ & $6.5 \mathrm{E}-03$ & $8.1 \mathrm{E}-04$ & $3.3 \mathrm{E}-03$ \\
\hline${ }^{16} \mathrm{O}$ & $1.9 \mathrm{E}-04$ & $1.5 \mathrm{E}-04$ & $1.2 \mathrm{E}-04$ & $3.4 \mathrm{E}-03$ & $4.2 \mathrm{E}-04$ & $1.0 \mathrm{E}-01$ & $1.9 \mathrm{E}-01$ \\
\hline${ }^{17} \mathrm{O}$ & $2.8 \mathrm{E}-02$ & $1.7 \mathrm{E}-02$ & $2.6 \mathrm{E}-04$ & $1.7 \mathrm{E}-03$ & $2.0 \mathrm{E}-03$ & $3.3 \mathrm{E}-03$ & $2.0 \mathrm{E}-02$ \\
\hline${ }^{18} \mathrm{O}$ & $9.2 \mathrm{E}-07$ & $7.1 \mathrm{E}-06$ & $1.1 \mathrm{E}-08$ & $1.7 \mathrm{E}-07$ & $1.4 \mathrm{E}-07$ & $4.4 \mathrm{E}-10$ & $1.6 \mathrm{E}-09$ \\
\hline${ }^{18} \mathrm{~F}$ & $1.7 \mathrm{E}-05$ & $4.3 \mathrm{E}-06$ & $1.1 \mathrm{E}-07$ & $2.1 \mathrm{E}-06$ & $2.0 \mathrm{E}-06$ & $3.2 \mathrm{E}-06$ & $1.8 \mathrm{E}-05$ \\
\hline${ }^{19} \mathrm{~F}$ & $1.8 \mathrm{E}-07$ & $1.1 \mathrm{E}-07$ & $1.0 \mathrm{E}-06$ & $7.5 \mathrm{E}-09$ & $1.2 \mathrm{E}-08$ & $1.1 \mathrm{E}-08$ & $3.3 \mathrm{E}-08$ \\
\hline${ }^{20} \mathrm{Ne}$ & $2.0 \mathrm{E}-01$ & $1.0 \mathrm{E}-01$ & $4.2 \mathrm{E}-02$ & $1.6 \mathrm{E}-01$ & $1.5 \mathrm{E}-01$ & $1.3 \mathrm{E}-03$ & $9.8 \mathrm{E}-04$ \\
\hline${ }^{21} \mathrm{Ne}$ & $3.7 \mathrm{E}-06$ & $7.7 \mathrm{E}-06$ & $5.9 \mathrm{E}-06$ & $4.2 \mathrm{E}-06$ & $9.2 \mathrm{E}-06$ & $2.3 \mathrm{E}-08$ & $2.5 \mathrm{E}-08$ \\
\hline${ }^{22} \mathrm{Ne}$ & $9.2 \mathrm{E}-09$ & 4.0E-09 & $1.9 \mathrm{E}-10$ & $2.8 \mathrm{E}-04$ & $5.4 \mathrm{E}-06$ & $2.5 \mathrm{E}-03$ & $4.8 \mathrm{E}-03$ \\
\hline${ }^{22} \mathrm{Na}$ & $1.1 \mathrm{E}-04$ & $4.9 \mathrm{E}-05$ & $2.1 \mathrm{E}-05$ & $1.1 \mathrm{E}-04$ & $9.6 \mathrm{E}-05$ & $1.3 \mathrm{E}-06$ & $6.4 \mathrm{E}-07$ \\
\hline${ }^{23} \mathrm{Na}$ & $2.0 \mathrm{E}-04$ & $5.7 \mathrm{E}-04$ & $9.8 \mathrm{E}-04$ & $1.6 \mathrm{E}-04$ & $1.5 \mathrm{E}-04$ & $1.4 \mathrm{E}-05$ & $2.1 \mathrm{E}-05$ \\
\hline${ }^{24} \mathrm{Mg}$ & $1.0 \mathrm{E}-05$ & $2.8 \mathrm{E}-05$ & $4.5 \mathrm{E}-05$ & $8.1 \mathrm{E}-06$ & $6.0 \mathrm{E}-06$ & $1.3 \mathrm{E}-06$ & $1.2 \mathrm{E}-06$ \\
\hline${ }^{25} \mathrm{Mg}$ & $4.1 \mathrm{E}-03$ & $9.1 \mathrm{E}-03$ & $6.3 \mathrm{E}-03$ & $8.0 \mathrm{E}-04$ & $6.8 \mathrm{E}-04$ & $4.4 \mathrm{E}-04$ & $2.5 \mathrm{E}-04$ \\
\hline${ }^{26} \mathrm{Mg}$ & $2.2 \mathrm{E}-04$ & $4.3 \mathrm{E}-04$ & $2.8 \mathrm{E}-04$ & $3.1 \mathrm{E}-05$ & $2.7 \mathrm{E}-05$ & $4.7 \mathrm{E}-05$ & $1.8 \mathrm{E}-05$ \\
\hline${ }^{26} \mathrm{Al}$ & $1.5 \mathrm{E}-03$ & $3.7 \mathrm{E}-03$ & $2.5 \mathrm{E}-03$ & $9.9 \mathrm{E}-05$ & $1.1 \mathrm{E}-04$ & $1.7 \mathrm{E}-05$ & $3.1 \mathrm{E}-05$ \\
\hline${ }^{27} \mathrm{Al}$ & $8.4 \mathrm{E}-03$ & $1.5 \mathrm{E}-02$ & $9.9 \mathrm{E}-03$ & $6.5 \mathrm{E}-04$ & $6.1 \mathrm{E}-04$ & $5.8 \mathrm{E}-05$ & $9.2 \mathrm{E}-05$ \\
\hline${ }^{28} \mathrm{Si}$ & $7.0 \mathrm{E}-02$ & $8.0 \mathrm{E}-02$ & $5.6 \mathrm{E}-02$ & $6.9 \mathrm{E}-02$ & $5.9 \mathrm{E}-02$ & $5.1 \mathrm{E}-04$ & $3.9 \mathrm{E}-04$ \\
\hline${ }^{29} \mathrm{Si}$ & $1.4 \mathrm{E}-03$ & $2.7 \mathrm{E}-03$ & $2.1 \mathrm{E}-03$ & $8.7 \mathrm{E}-04$ & $7.8 \mathrm{E}-04$ & $2.5 \mathrm{E}-05$ & $1.6 \mathrm{E}-05$ \\
\hline${ }^{30} \mathrm{Si}$ & $2.2 \mathrm{E}-02$ & $2.6 \mathrm{E}-02$ & $2.4 \mathrm{E}-02$ & $1.1 \mathrm{E}-02$ & $1.5 \mathrm{E}-02$ & $1.8 \mathrm{E}-05$ & $1.3 \mathrm{E}-05$ \\
\hline${ }^{31} \mathrm{P}$ & $2.2 \mathrm{E}-02$ & $2.4 \mathrm{E}-02$ & $2.6 \mathrm{E}-02$ & $5.2 \mathrm{E}-03$ & $9.6 \mathrm{E}-03$ & $6.1 \mathrm{E}-06$ & $4.0 \mathrm{E}-06$ \\
\hline${ }^{32} \mathrm{~S}$ & $7.2 \mathrm{E}-02$ & $1.7 \mathrm{E}-01$ & $2.1 \mathrm{E}-01$ & $4.2 \mathrm{E}-03$ & $3.0 \mathrm{E}-02$ & $3.0 \mathrm{E}-04$ & $2.0 \mathrm{E}-04$ \\
\hline${ }^{33} \mathrm{~S}$ & $2.5 \mathrm{E}-04$ & $3.2 \mathrm{E}-03$ & $6.4 \mathrm{E}-03$ & $9.3 \mathrm{E}-07$ & $2.7 \mathrm{E}-05$ & $2.4 \mathrm{E}-06$ & $1.6 \mathrm{E}-06$ \\
\hline${ }^{34} \mathrm{~S}$ & $1.8 \mathrm{E}-04$ & $4.2 \mathrm{E}-03$ & $9.4 \mathrm{E}-03$ & $1.3 \mathrm{E}-06$ & $1.6 \mathrm{E}-05$ & $1.4 \mathrm{E}-05$ & $9.2 \mathrm{E}-06$ \\
\hline${ }^{35} \mathrm{Cl}$ & $1.3 \mathrm{E}-04$ & $9.7 \mathrm{E}-03$ & $3.0 \mathrm{E}-02$ & $2.2 \mathrm{E}-06$ & $1.2 \mathrm{E}-05$ & $1.9 \mathrm{E}-06$ & $1.3 \mathrm{E}-06$ \\
\hline${ }^{37} \mathrm{Cl}$ & $1.1 \mathrm{E}-07$ & $1.2 \mathrm{E}-05$ & $8.2 \mathrm{E}-06$ & $1.5 \mathrm{E}-07$ & $9.5 \mathrm{E}-08$ & $6.4 \mathrm{E}-07$ & 4.3E-07 \\
\hline${ }^{36} \mathrm{Ar}$ & $7.9 \mathrm{E}-06$ & $1.6 \mathrm{E}-03$ & $6.2 \mathrm{E}-03$ & $1.2 \mathrm{E}-05$ & $2.0 \mathrm{E}-06$ & $5.8 \mathrm{E}-05$ & $3.9 \mathrm{E}-05$ \\
\hline${ }^{37} \mathrm{Ar}$ & $2.0 \mathrm{E}-05$ & $5.5 \mathrm{E}-03$ & $3.3 \mathrm{E}-02$ & $2.6 \mathrm{E}-05$ & $3.1 \mathrm{E}-05$ & $5.2 \mathrm{E}-08$ & $2.1 \mathrm{E}-07$ \\
\hline${ }^{38} \mathrm{Ar}$ & $1.1 \mathrm{E}-05$ & $2.1 \mathrm{E}-03$ & $2.6 \mathrm{E}-02$ & $3.4 \mathrm{E}-06$ & $9.3 \mathrm{E}-06$ & $1.2 \mathrm{E}-05$ & $7.7 \mathrm{E}-06$ \\
\hline${ }^{39} \mathrm{~K}$ & $3.2 \mathrm{E}-06$ & $2.0 \mathrm{E}-04$ & $7.3 \mathrm{E}-03$ & $6.6 \mathrm{E}-07$ & $1.2 \mathrm{E}-06$ & $2.6 \mathrm{E}-06$ & $1.7 \mathrm{E}-06$ \\
\hline${ }^{40} \mathrm{Ca}$ & $1.7 \mathrm{E}-05$ & $5.7 \mathrm{E}-05$ & $5.0 \mathrm{E}-03$ & $3.0 \mathrm{E}-05$ & $3.0 \mathrm{E}-05$ & $4.5 \mathrm{E}-05$ & $3.0 \mathrm{E}-05$ \\
\hline${ }^{41} \mathrm{Ca}$ & $5.4 \mathrm{E}-10$ & $2.7 \mathrm{E}-08$ & $3.7 \mathrm{E}-06$ & $4.2 \mathrm{E}-09$ & $4.2 \mathrm{E}-09$ & $7.4 \mathrm{E}-09$ & $4.9 \mathrm{E}-09$ \\
\hline${ }^{42} \mathrm{Ca}$ & $2.2 \mathrm{E}-11$ & 8.6E-09 & $1.6 \mathrm{E}-06$ & $0.0 \mathrm{E}+00$ & $1.4 \mathrm{E}-10$ & $0.0 \mathrm{E}+00$ & $0.0 \mathrm{E}+00$ \\
\hline
\end{tabular}

${ }^{a}$ Results are obtained by using recommended reaction rates discussed in $\S \S 3.1$.

${ }^{\mathrm{b}}$ Model properties are summarized in Table 1. 
Table 5. FINAL ABUNDANCE CHANGES X X $_{i, r e c}$ RESULTING FROM REACTION RATE VARIATIONS FOR ONe NOVA MODEL P1 $\left(\mathrm{T}_{P E A K}=0.290 \mathrm{GK}\right)$

\begin{tabular}{|c|c|c|c|c|c|c|c|}
\hline \multirow[t]{2}{*}{ Reaction } & \multirow[t]{2}{*}{ Isotope i } & \multicolumn{6}{|c|}{ Reaction rate multiplied by } \\
\hline & & 100 & 10 & 2 & 0.5 & 0.1 & 0.01 \\
\hline${ }^{3} \mathrm{He}(\alpha, \gamma)^{7} \mathrm{Be}$ & ${ }^{7} \mathrm{Be}$ & $\ldots$ & $\ldots$ & 0.43 & 1.3 & $\ldots$ & $\ldots$ \\
\hline${ }^{7} \mathrm{Be}(\mathrm{p}, \gamma){ }^{8} \mathrm{~B}$ & ${ }^{7} \mathrm{Be}$ & $\ldots$ & $\ldots$ & 0.10 & 4.0 & $\ldots$ & $\ldots$ \\
\hline${ }^{8} \mathrm{~B}(\mathrm{p}, \gamma)^{9} \mathrm{C}$ & ${ }^{7} \mathrm{Be}$ & $\ldots$ & 0.67 & 0.92 & 1.1 & 1.1 & $\ldots$ \\
\hline${ }^{13} \mathrm{~N}(\mathrm{p}, \gamma){ }^{14} \mathrm{O}$ & ${ }^{13} \mathrm{C}$ & $\ldots$ & $\ldots$ & 0.87 & 1.1 & $\ldots$ & $\cdots$ \\
\hline${ }^{14} \mathrm{~N}(\mathrm{p}, \gamma){ }^{15} \mathrm{O}$ & ${ }^{15} \mathrm{~N}$ & $\ldots$ & $\ldots$ & 1.6 & 0.61 & $\ldots$ & $\ldots$ \\
\hline${ }^{15} \mathrm{~N}(\mathrm{p}, \gamma){ }^{16} \mathrm{O}$ & ${ }^{16} \mathrm{O}$ & $\ldots$ & $\ldots$ & 1.3 & 0.89 & $\ldots$ & $\ldots$ \\
\hline \multirow[t]{2}{*}{${ }^{15} \mathrm{~N}(\mathrm{p}, \alpha){ }^{12} \mathrm{C}$} & ${ }^{15} \mathrm{~N}$ & $\ldots$ & $\ldots$ & 0.49 & 1.9 & $\ldots$ & $\cdots$ \\
\hline & ${ }^{16} \mathrm{O}$ & $\ldots$ & $\ldots$ & 0.89 & 1.3 & $\ldots$ & $\ldots$ \\
\hline${ }^{16} \mathrm{O}(\mathrm{p}, \gamma)^{17} \mathrm{~F}$ & ${ }^{16} \mathrm{O}$ & $\ldots$ & $\ldots$ & 0.35 & 21 & $\ldots$ & $\ldots$ \\
\hline \multirow[t]{7}{*}{${ }^{17} \mathrm{O}(\mathrm{p}, \gamma){ }^{18} \mathrm{~F}$} & ${ }^{12} \mathrm{C}$ & $\ldots$ & 1.2 & 1.0 & 0.95 & 0.95 & $\ldots$ \\
\hline & ${ }^{13} \mathrm{C}$ & $\ldots$ & 1.2 & 1.0 & 0.96 & 0.96 & $\cdots$ \\
\hline & ${ }^{15} \mathrm{~N}$ & $\ldots$ & 1.5 & 1.1 & 0.90 & 0.88 & $\ldots$ \\
\hline & ${ }^{17} \mathrm{O}$ & $\ldots$ & 0.54 & 0.89 & 1.0 & 1.1 & $\ldots$ \\
\hline & ${ }^{18} \mathrm{~F}$ & $\ldots$ & 5.2 & 1.8 & 0.53 & 0.11 & $\ldots$ \\
\hline & ${ }^{18} \mathrm{O}$ & $\ldots$ & 5.3 & 1.8 & 0.53 & 0.11 & $\ldots$ \\
\hline & ${ }^{19} \mathrm{~F}$ & $\ldots$ & 5.3 & 1.8 & 0.53 & 0.11 & $\ldots$ \\
\hline \multirow[t]{7}{*}{${ }^{17} \mathrm{O}(\mathrm{p}, \alpha){ }^{14} \mathrm{~N}$} & ${ }^{12} \mathrm{C}$ & $\ldots$ & 1.2 & 1.0 & 0.90 & 0.81 & $\ldots$ \\
\hline & ${ }^{13} \mathrm{C}$ & $\ldots$ & 1.2 & 1.0 & 0.91 & 0.83 & $\cdots$ \\
\hline & ${ }^{14} \mathrm{~N}$ & $\cdots$ & 1.2 & 1.1 & 0.89 & 0.74 & $\cdots$ \\
\hline & ${ }^{17} \mathrm{O}$ & $\ldots$ & 0.029 & 0.57 & 1.4 & 2.0 & $\ldots$ \\
\hline & ${ }^{18} \mathrm{~F}$ & $\ldots$ & 0.041 & 0.59 & 1.4 & 2.0 & $\ldots$ \\
\hline & ${ }^{18} \mathrm{O}$ & $\ldots$ & 0.042 & 0.59 & 1.4 & 2.0 & $\ldots$ \\
\hline & ${ }^{19} \mathrm{~F}$ & $\ldots$ & 0.067 & 0.61 & 1.3 & 1.9 & $\cdots$ \\
\hline \multirow[t]{8}{*}{${ }^{17} \mathrm{~F}(\mathrm{p}, \gamma){ }^{18} \mathrm{Ne}$} & ${ }^{12} \mathrm{C}$ & $\ldots$ & 1.2 & 1.0 & 0.90 & 0.86 & $\ldots$ \\
\hline & ${ }^{13} \mathrm{C}$ & $\cdots$ & 1.3 & 1.1 & 0.91 & 0.87 & $\cdots$ \\
\hline & ${ }^{16} \mathrm{O}$ & $\ldots$ & 1.4 & 1.1 & 0.95 & 0.89 & $\cdots$ \\
\hline & ${ }^{15} \mathrm{~N}$ & $\cdots$ & 0.88 & 0.94 & 1.0 & 1.0 & $\cdots$ \\
\hline & ${ }^{17} \mathrm{O}$ & $\cdots$ & 0.057 & 0.71 & 1.2 & 1.4 & $\ldots$ \\
\hline & ${ }^{18} \mathrm{~F}$ & $\cdots$ & 0.056 & 0.71 & 1.2 & 1.4 & $\cdots$ \\
\hline & ${ }^{18} \mathrm{O}$ & $\ldots$ & 0.059 & 0.71 & 1.2 & 1.4 & $\cdots$ \\
\hline & ${ }^{19} \mathrm{~F}$ & $\ldots$ & 0.056 & 0.72 & 1.2 & 1.4 & $\cdots$ \\
\hline \multirow[t]{2}{*}{${ }^{18} \mathrm{O}(\mathrm{p}, \alpha)^{15} \mathrm{~N}$} & ${ }^{18} \mathrm{O}$ & $\ldots$ & $\ldots$ & 0.53 & 1.7 & $\cdots$ & $\cdots$ \\
\hline & ${ }^{19} \mathrm{~F}$ & $\ldots$ & $\cdots$ & 0.61 & 1.7 & $\cdots$ & $\cdots$ \\
\hline \multirow[t]{2}{*}{${ }^{18} \mathrm{~F}(\mathrm{p}, \gamma){ }^{19} \mathrm{Ne}$} & ${ }^{16} \mathrm{O}$ & $\cdots$ & 2.1 & 1.2 & 0.95 & 0.89 & $\cdots$ \\
\hline & ${ }^{19} \mathrm{~F}$ & $\ldots$ & 3.2 & 1.2 & 0.89 & 0.78 & $\cdots$ \\
\hline \multirow[t]{5}{*}{${ }^{18} \mathrm{~F}(\mathrm{p}, \alpha){ }^{15} \mathrm{O}$} & ${ }^{15} \mathrm{~N}$ & 1.0 & 0.94 & 0.94 & 1.1 & 1.3 & 3.6 \\
\hline & ${ }^{16} \mathrm{O}$ & 0.89 & 0.89 & 0.95 & 1.2 & 2.1 & 12 \\
\hline & ${ }^{18} \mathrm{~F}$ & 0.021 & 0.17 & 0.59 & 1.7 & 6.5 & 41 \\
\hline & ${ }^{18} \mathrm{O}$ & 0.020 & 0.16 & 0.60 & 1.7 & 6.3 & 41 \\
\hline & ${ }^{19} \mathrm{~F}$ & 0.013 & 0.12 & 0.54 & 1.8 & 8.3 & 56 \\
\hline \multirow[t]{7}{*}{${ }^{20} \mathrm{Ne}(\mathrm{p}, \gamma){ }^{21} \mathrm{Na}$} & ${ }^{20} \mathrm{Ne}$ & $\ldots$ & $\ldots$ & 0.85 & 1.1 & $\ldots$ & $\ldots$ \\
\hline & ${ }^{21} \mathrm{Ne}$ & $\ldots$ & $\cdots$ & 1.7 & 0.54 & $\ldots$ & $\cdots$ \\
\hline & ${ }^{22} \mathrm{Na}$ & $\cdots$ & $\cdots$ & 1.7 & 0.59 & $\cdots$ & $\cdots$ \\
\hline & ${ }^{22} \mathrm{Ne}$ & $\ldots$ & $\cdots$ & 1.6 & 0.57 & $\ldots$ & $\cdots$ \\
\hline & ${ }^{23} \mathrm{Na}$ & $\cdots$ & $\cdots$ & 1.7 & 0.55 & $\cdots$ & $\cdots$ \\
\hline & ${ }^{24} \mathrm{Mg}$ & $\ldots$ & $\ldots$ & 1.7 & 0.57 & $\ldots$ & $\ldots$ \\
\hline & ${ }^{25} \mathrm{Mg}$ & $\ldots$ & $\ldots$ & 1.7 & 0.56 & $\ldots$ & $\ldots$ \\
\hline
\end{tabular}


Table 5-Continued

\begin{tabular}{|c|c|c|c|c|c|c|c|}
\hline \multirow[t]{2}{*}{ Reaction } & \multirow[t]{2}{*}{ Isotope i } & \multicolumn{6}{|c|}{ Reaction rate multiplied by } \\
\hline & & 100 & 10 & 2 & 0.5 & 0.1 & 0.01 \\
\hline & ${ }^{26} \mathrm{Al}$ & $\ldots$ & $\ldots$ & 1.7 & 0.55 & $\ldots$ & $\ldots$ \\
\hline & ${ }^{26} \mathrm{Mg}$ & $\ldots$ & $\ldots$ & 1.6 & 0.55 & $\ldots$ & $\ldots$ \\
\hline & ${ }^{27} \mathrm{Al}$ & $\cdots$ & $\cdots$ & 1.7 & 0.56 & $\ldots$ & $\cdots$ \\
\hline & ${ }^{28} \mathrm{Si}$ & $\ldots$ & $\ldots$ & 1.4 & 0.69 & $\ldots$ & $\ldots$ \\
\hline & ${ }^{29} \mathrm{Si}$ & $\cdots$ & $\cdots$ & 1.4 & 0.71 & $\ldots$ & $\cdots$ \\
\hline & ${ }^{30} \mathrm{Si}$ & $\ldots$ & $\ldots$ & 1.1 & 0.86 & $\ldots$ & $\ldots$ \\
\hline${ }^{21} \mathrm{Ne}(\mathrm{p}, \gamma)^{22} \mathrm{Na}$ & ${ }^{21} \mathrm{Ne}$ & $\ldots$ & $\ldots$ & 0.46 & 2.3 & $\ldots$ & $\ldots$ \\
\hline \multirow[t]{4}{*}{${ }^{21} \mathrm{Na}(\mathrm{p}, \gamma){ }^{22} \mathrm{Mg}$} & ${ }^{22} \mathrm{Na}$ & 0.83 & 0.88 & 1.0 & 1.1 & 1.3 & 1.5 \\
\hline & ${ }^{22} \mathrm{Ne}$ & 0.79 & 0.85 & 0.95 & 1.1 & 1.2 & 1.5 \\
\hline & ${ }^{23} \mathrm{Na}$ & 0.95 & 0.95 & 0.95 & 1.1 & 1.3 & 2.1 \\
\hline & ${ }^{24} \mathrm{Mg}$ & 0.96 & 0.96 & 0.98 & 1.1 & 1.4 & 2.2 \\
\hline${ }^{22} \mathrm{Ne}(\mathrm{p}, \gamma)^{23} \mathrm{Na}$ & ${ }^{22} \mathrm{Ne}$ & 0.99 & 1.0 & 1.0 & 1.3 & 460 & \\
\hline \multirow[t]{2}{*}{${ }^{22} \mathrm{Na}(\mathrm{p}, \gamma)^{23} \mathrm{Mg}$} & ${ }^{22} \mathrm{Na}$ & $\ldots$ & $\ldots$ & 0.65 & 1.7 & $\ldots$ & $\cdots$ \\
\hline & ${ }^{22} \mathrm{Ne}$ & $\ldots$ & $\cdots$ & 0.62 & 1.6 & $\ldots$ & $\ldots$ \\
\hline \multirow[t]{13}{*}{${ }^{23} \mathrm{Na}(\mathrm{p}, \gamma){ }^{24} \mathrm{Mg}$} & ${ }^{20} \mathrm{Ne}$ & $\ldots$ & 0.75 & 0.90 & 1.0 & 1.2 & 1.2 \\
\hline & ${ }^{21} \mathrm{Ne}$ & $\ldots$ & 0.76 & 0.92 & 1.1 & 1.2 & 1.2 \\
\hline & ${ }^{22} \mathrm{Na}$ & $\ldots$ & 0.78 & 0.91 & 1.1 & 1.3 & 1.3 \\
\hline & ${ }^{22} \mathrm{Ne}$ & $\ldots$ & 0.75 & 0.90 & 1.1 & 1.2 & 1.2 \\
\hline & ${ }^{23} \mathrm{Na}$ & $\ldots$ & 0.24 & 0.75 & 1.3 & 1.6 & 1.7 \\
\hline & ${ }^{24} \mathrm{Mg}$ & $\ldots$ & 2.5 & 1.5 & 0.64 & 0.16 & 0.018 \\
\hline & ${ }^{25} \mathrm{Mg}$ & $\ldots$ & 2.1 & 1.4 & 0.63 & 0.17 & 0.027 \\
\hline & ${ }^{26} \mathrm{Al}$ & $\ldots$ & 2.1 & 1.4 & 0.63 & 0.17 & 0.029 \\
\hline & ${ }^{26} \mathrm{Mg}$ & & 2.1 & 1.4 & 0.64 & 0.17 & 0.028 \\
\hline & ${ }^{27} \mathrm{Al}$ & $\ldots$ & 2.0 & 1.4 & 0.64 & 0.19 & 0.049 \\
\hline & ${ }^{28} \mathrm{Si}$ & $\ldots$ & 1.7 & 1.3 & 0.77 & 0.47 & 0.37 \\
\hline & ${ }^{29} \mathrm{Si}$ & $\ldots$ & 1.5 & 1.1 & 0.86 & 0.63 & 0.56 \\
\hline & ${ }^{30} \mathrm{Si}$ & $\ldots$ & 1.1 & 1.0 & 0.91 & 0.86 & 0.86 \\
\hline \multirow[t]{9}{*}{${ }^{23} \mathrm{Na}(\mathrm{p}, \alpha){ }^{20} \mathrm{Ne}$} & ${ }^{20} \mathrm{Ne}$ & $\ldots$ & $\ldots$ & 1.0 & 0.90 & $\ldots$ & $\cdots$ \\
\hline & ${ }^{22} \mathrm{Ne}$ & $\ldots$ & $\ldots$ & 1.1 & 0.90 & $\cdots$ & $\cdots$ \\
\hline & ${ }^{23} \mathrm{Na}$ & $\ldots$ & $\ldots$ & 0.65 & 1.5 & $\cdots$ & $\cdots$ \\
\hline & ${ }^{24} \mathrm{Mg}$ & $\ldots$ & $\ldots$ & 0.64 & 1.5 & $\cdots$ & $\ldots$ \\
\hline & ${ }^{25} \mathrm{Mg}$ & $\ldots$ & $\ldots$ & 0.63 & 1.4 & $\cdots$ & $\cdots$ \\
\hline & ${ }^{26} \mathrm{Al}$ & $\ldots$ & $\ldots$ & 0.63 & 1.4 & $\cdots$ & $\ldots$ \\
\hline & ${ }^{26} \mathrm{Mg}$ & $\ldots$ & $\ldots$ & 0.64 & 1.4 & $\ldots$ & \\
\hline & ${ }^{27} \mathrm{Al}$ & $\ldots$ & $\cdots$ & 0.64 & 1.4 & $\cdots$ & $\cdots$ \\
\hline & ${ }^{28} \mathrm{Si}$ & $\ldots$ & $\ldots$ & 0.77 & 1.2 & $\ldots$ & $\ldots$ \\
\hline \multirow[t]{11}{*}{${ }^{23} \mathrm{Mg}(\mathrm{p}, \gamma){ }^{24} \mathrm{Al}$} & ${ }^{20} \mathrm{Ne}$ & 0.75 & 0.90 & 0.95 & 1.0 & 1.0 & 1.0 \\
\hline & ${ }^{21} \mathrm{Ne}$ & 0.78 & 0.92 & 1.0 & 1.0 & 1.0 & 1.0 \\
\hline & ${ }^{22} \mathrm{Na}$ & 0.80 & 0.91 & 1.0 & 1.1 & 1.1 & 1.1 \\
\hline & ${ }^{22} \mathrm{Ne}$ & 0.77 & 0.90 & 0.99 & 1.0 & 1.0 & 1.0 \\
\hline & ${ }^{23} \mathrm{Na}$ & 0.75 & 0.90 & 1.0 & 1.0 & 1.1 & 1.1 \\
\hline & ${ }^{24} \mathrm{Mg}$ & 0.76 & 0.92 & 1.0 & 1.0 & 1.0 & 1.0 \\
\hline & ${ }^{25} \mathrm{Mg}$ & 0.61 & 0.85 & 0.98 & 1.0 & 1.0 & 1.0 \\
\hline & ${ }^{26} \mathrm{Al}$ & 0.62 & 0.87 & 0.93 & 1.0 & 1.0 & 1.0 \\
\hline & ${ }^{26} \mathrm{Mg}$ & 0.59 & 0.82 & 0.95 & 1.0 & 1.0 & 1.0 \\
\hline & ${ }^{27} \mathrm{Al}$ & 0.83 & 0.90 & 0.98 & 1.0 & 1.0 & 1.0 \\
\hline & ${ }^{28} \mathrm{Si}$ & 1.7 & 1.3 & 1.0 & 0.97 & 0.96 & 0.94 \\
\hline
\end{tabular}


Table 5-Continued

\begin{tabular}{|c|c|c|c|c|c|c|c|}
\hline \multirow[t]{2}{*}{ Reaction } & \multirow[t]{2}{*}{ Isotope i } & \multicolumn{6}{|c|}{ Reaction rate multiplied by } \\
\hline & & 100 & 10 & 2 & 0.5 & 0.1 & 0.01 \\
\hline \multirow{6}{*}{${ }^{25} \mathrm{Mg}(\mathrm{p}, \gamma)^{26} \mathrm{Al}^{g}$} & ${ }^{29} \mathrm{Si}$ & 1.9 & 1.4 & 1.1 & 1.0 & 0.93 & 0.93 \\
\hline & ${ }^{30} \mathrm{Si}$ & 1.5 & 1.2 & 1.0 & 0.95 & 0.95 & 0.95 \\
\hline & ${ }^{31} \mathrm{P}$ & 1.2 & 1.1 & 1.0 & 1.0 & 1.0 & 1.0 \\
\hline & ${ }^{25} \mathrm{Mg}$ & $\ldots$ & $\ldots$ & 0.54 & 1.7 & $\ldots$ & $\ldots$ \\
\hline & ${ }^{26} \mathrm{Al}$ & $\ldots$ & $\ldots$ & 1.1 & 0.80 & $\cdots$ & $\cdots$ \\
\hline & ${ }^{26} \mathrm{Mg}$ & $\ldots$ & $\ldots$ & 0.55 & 1.6 & $\cdots$ & $\cdots$ \\
\hline${ }^{25} \mathrm{Mg}(\mathrm{p}, \gamma)^{26} \mathrm{Al}^{m}$ & ${ }^{26} \mathrm{Mg}$ & $\ldots$ & $\ldots$ & 1.8 & 0.55 & $\cdots$ & $\cdots$ \\
\hline${ }^{26} \mathrm{Mg}(\mathrm{p}, \gamma){ }^{27} \mathrm{Al}$ & ${ }^{26} \mathrm{Mg}$ & $\ldots$ & $\ldots$ & 0.55 & 1.7 & $\ldots$ & $\ldots$ \\
\hline \multirow[t]{4}{*}{${ }^{25} \mathrm{Al}(\mathrm{p}, \gamma){ }^{26} \mathrm{Si}$} & ${ }^{25} \mathrm{Mg}$ & 0.83 & 0.98 & 1.0 & 1.0 & 1.0 & 1.0 \\
\hline & ${ }^{26} \mathrm{Mg}$ & 0.86 & 0.95 & 1.0 & 1.0 & 1.0 & 1.0 \\
\hline & ${ }^{26} \mathrm{Al}$ & 0.73 & 0.93 & 1.0 & 1.0 & 1.0 & 1.0 \\
\hline & ${ }^{27} \mathrm{Al}$ & 0.71 & 0.88 & 0.98 & 1.0 & 1.0 & 1.0 \\
\hline${ }^{26} \mathrm{Al}^{g}(\mathrm{p}, \gamma){ }^{27} \mathrm{Si}$ & ${ }^{26} \mathrm{Al}$ & $\ldots$ & 0.031 & 0.37 & 2.4 & $\cdots$ & $\cdots$ \\
\hline${ }^{26} \mathrm{Al}^{m}(\mathrm{p}, \gamma)^{27} \mathrm{Si}$ & ${ }^{26} \mathrm{Mg}$ & 0.13 & 0.50 & 0.86 & 1.1 & 1.3 & 1.3 \\
\hline \multirow[t]{6}{*}{${ }^{27} \mathrm{Si}(\mathrm{p}, \gamma)^{28} \mathrm{P}$} & ${ }^{29} \mathrm{Si}$ & $\ldots$ & 1.0 & 1.0 & 1.1 & 1.2 & $\cdots$ \\
\hline & ${ }^{32} \mathrm{~S}$ & $\cdots$ & 1.1 & 1.0 & 0.93 & 0.78 & $\cdots$ \\
\hline & ${ }^{33} \mathrm{~S}$ & $\ldots$ & 1.2 & 1.1 & 0.92 & 0.72 & $\cdots$ \\
\hline & ${ }^{34} \mathrm{~S}$ & $\ldots$ & 1.2 & 1.1 & 0.89 & 0.67 & $\ldots$ \\
\hline & ${ }^{35} \mathrm{Cl}$ & $\ldots$ & 1.3 & 1.1 & 0.85 & 0.65 & $\ldots$ \\
\hline & ${ }^{36} \mathrm{Ar}$ & $\ldots$ & 1.3 & 1.1 & 0.86 & 0.67 & $\ldots$ \\
\hline \multirow[t]{8}{*}{${ }^{28} \mathrm{Si}(\mathrm{p}, \gamma){ }^{29} \mathrm{P}$} & ${ }^{28} \mathrm{Si}$ & $\ldots$ & $\ldots$ & 0.77 & 1.4 & $\ldots$ & $\ldots$ \\
\hline & ${ }^{29} \mathrm{Si}$ & $\cdots$ & $\cdots$ & 1.4 & 0.79 & $\cdots$ & $\cdots$ \\
\hline & ${ }^{30} \mathrm{Si}$ & $\ldots$ & $\ldots$ & 1.0 & 0.82 & $\ldots$ & \\
\hline & ${ }^{32} \mathrm{~S}$ & $\ldots$ & $\ldots$ & 1.2 & 0.72 & $\ldots$ & $\ldots$ \\
\hline & ${ }^{33} \mathrm{~S}$ & $\ldots$ & $\ldots$ & 1.3 & 0.68 & $\ldots$ & $\ldots$ \\
\hline & ${ }^{34} \mathrm{~S}$ & $\ldots$ & $\ldots$ & 1.3 & 0.67 & $\ldots$ & $\cdots$ \\
\hline & ${ }^{35} \mathrm{Cl}$ & $\ldots$ & $\ldots$ & 1.4 & 0.65 & $\ldots$ & $\cdots$ \\
\hline & ${ }^{36} \mathrm{Ar}$ & $\ldots$ & $\ldots$ & 1.4 & 0.68 & $\ldots$ & $\ldots$ \\
\hline \multirow[t]{4}{*}{${ }^{28} \mathrm{P}(\mathrm{p}, \gamma){ }^{29} \mathrm{~S}$} & ${ }^{33} \mathrm{~S}$ & 1.3 & 1.2 & 1.0 & 1.0 & 1.0 & 1.0 \\
\hline & ${ }^{34} \mathrm{~S}$ & 1.3 & 1.2 & 1.0 & 0.94 & 0.94 & 0.94 \\
\hline & ${ }^{35} \mathrm{Cl}$ & 1.4 & 1.2 & 1.0 & 0.92 & 0.92 & 0.92 \\
\hline & ${ }^{36} \mathrm{Ar}$ & 1.4 & 1.2 & 1.0 & 0.97 & 0.95 & 0.94 \\
\hline \multirow[t]{2}{*}{${ }^{29} \mathrm{Si}(\mathrm{p}, \gamma){ }^{30} \mathrm{P}$} & ${ }^{29} \mathrm{Si}$ & $\ldots$ & 0.070 & 0.46 & 2.1 & 9.3 & $\ldots$ \\
\hline & ${ }^{30} \mathrm{Si}$ & $\ldots$ & 1.0 & 1.0 & 0.95 & 0.86 & \\
\hline \multirow[t]{10}{*}{${ }^{29} \mathrm{P}(\mathrm{p}, \gamma){ }^{30} \mathrm{~S}$} & ${ }^{29} \mathrm{Si}$ & 0.66 & 0.86 & 1.0 & 1.0 & 1.0 & 1.0 \\
\hline & ${ }^{30} \mathrm{Si}$ & 0.55 & 0.68 & 0.91 & 1.0 & 1.0 & 1.0 \\
\hline & ${ }^{31} \mathrm{P}$ & 0.68 & 0.82 & 0.95 & 1.0 & 1.0 & 1.0 \\
\hline & ${ }^{32} \mathrm{~S}$ & 1.2 & 1.1 & 1.0 & 0.99 & 0.96 & 0.96 \\
\hline & ${ }^{33} \mathrm{~S}$ & 1.6 & 1.4 & 1.1 & 1.0 & 0.96 & 0.96 \\
\hline & ${ }^{34} \mathrm{~S}$ & 1.7 & 1.4 & 1.1 & 0.94 & 0.89 & 0.89 \\
\hline & ${ }^{35} \mathrm{Cl}$ & 1.8 & 1.4 & 1.1 & 0.92 & 0.92 & 0.92 \\
\hline & ${ }^{36} \mathrm{Ar}$ & 1.9 & 1.4 & 1.1 & 0.96 & 0.91 & 0.91 \\
\hline & ${ }^{37} \mathrm{Ar}$ & 1.3 & 1.1 & 1.0 & 1.0 & 1.0 & 1.0 \\
\hline & ${ }^{37} \mathrm{Cl}$ & 1.2 & 1.1 & 1.1 & 1.0 & 1.0 & 1.0 \\
\hline \multirow[t]{3}{*}{${ }^{30} \mathrm{P}(\mathrm{p}, \gamma){ }^{31} \mathrm{~S}$} & ${ }^{30} \mathrm{Si}$ & 0.0095 & 0.11 & 0.55 & 1.7 & 3.8 & 5.0 \\
\hline & ${ }^{31} \mathrm{P}$ & 1.2 & 1.1 & 1.1 & 0.86 & 0.40 & 0.10 \\
\hline & ${ }^{32} \mathrm{~S}$ & 1.2 & 1.2 & 1.1 & 0.82 & 0.33 & 0.081 \\
\hline
\end{tabular}


Table 5-Continued

\begin{tabular}{|c|c|c|c|c|c|c|c|}
\hline \multirow[t]{2}{*}{ Reaction } & \multirow[t]{2}{*}{ Isotope $\mathrm{i}$} & \multicolumn{6}{|c|}{ Reaction rate multiplied by } \\
\hline & & 100 & 10 & 2 & 0.5 & 0.1 & 0.01 \\
\hline \multirow{14}{*}{${ }^{31} \mathrm{P}(\mathrm{p}, \alpha){ }^{28} \mathrm{Si}$} & ${ }^{33} \mathrm{~S}$ & 1.4 & 1.3 & 1.2 & 0.80 & 0.31 & 0.080 \\
\hline & ${ }^{34} \mathrm{~S}$ & 1.3 & 1.3 & 1.2 & 0.78 & 0.29 & 0.078 \\
\hline & ${ }^{35} \mathrm{Cl}$ & 1.4 & 1.4 & 1.2 & 0.75 & 0.29 & 0.10 \\
\hline & ${ }^{36} \mathrm{Ar}$ & 1.5 & 1.4 & 1.2 & 0.76 & 0.33 & 0.15 \\
\hline & ${ }^{37} \mathrm{Ar}$ & 1.2 & 1.1 & 1.1 & 0.95 & 0.80 & 0.75 \\
\hline & ${ }^{28} \mathrm{Si}$ & $\ldots$ & 1.4 & 1.1 & 0.96 & $\cdots$ & $\cdots$ \\
\hline & ${ }^{29} \mathrm{Si}$ & $\ldots$ & 1.5 & 1.1 & 0.93 & $\ldots$ & $\cdots$ \\
\hline & ${ }^{30} \mathrm{Si}$ & $\ldots$ & 1.3 & 1.0 & 0.95 & $\ldots$ & $\ldots$ \\
\hline & ${ }^{31} \mathrm{P}$ & $\ldots$ & 0.68 & 0.95 & 1.0 & $\ldots$ & $\ldots$ \\
\hline & ${ }^{32} \mathrm{~S}$ & $\ldots$ & 0.56 & 0.92 & 1.0 & $\cdots$ & $\cdots$ \\
\hline & ${ }^{33} \mathrm{~S}$ & $\ldots$ & 0.52 & 0.92 & 1.1 & $\ldots$ & $\ldots$ \\
\hline & ${ }^{34} \mathrm{~S}$ & $\cdots$ & 0.52 & 0.89 & 1.1 & $\cdots$ & $\ldots$ \\
\hline & ${ }^{35} \mathrm{Cl}$ & $\ldots$ & 0.53 & 0.92 & 1.0 & $\cdots$ & $\ldots$ \\
\hline & ${ }^{36} \mathrm{Ar}$ & $\ldots$ & 0.57 & 0.91 & 1.0 & $\ldots$ & $\ldots$ \\
\hline \multirow{3}{*}{${ }^{32} \mathrm{~S}(\mathrm{p}, \gamma){ }^{33} \mathrm{Cl}$} & ${ }^{37} \mathrm{Ar}$ & $\ldots$ & 0.90 & 1.0 & 1.0 & $\ldots$ & $\cdots$ \\
\hline & ${ }^{33} \mathrm{~S}$ & $\ldots$ & $\ldots$ & 2.0 & 0.52 & & $\ldots$ \\
\hline & ${ }^{34} \mathrm{~S}$ & $\ldots$ & $\ldots$ & 1.9 & 0.49 & $\cdots$ & $\ldots$ \\
\hline \multirow{8}{*}{${ }^{33} \mathrm{~S}(\mathrm{p}, \gamma){ }^{34} \mathrm{Cl}$} & ${ }^{35} \mathrm{Cl}$ & $\ldots$ & $\ldots$ & 1.9 & 0.50 & $\ldots$ & $\ldots$ \\
\hline & ${ }^{36} \mathrm{Ar}$ & $\cdots$ & . & 1.9 & 0.53 & $\cdots$ & $\cdots$ \\
\hline & ${ }^{37} \mathrm{Ar}$ & $\cdots$ & $\ldots$ & 1.3 & 0.85 & $\ldots$ & $\ldots$ \\
\hline & ${ }^{37} \mathrm{Cl}$ & $\ldots$ & $\ldots$ & 1.2 & 1.0 & $\ldots$ & $\cdots$ \\
\hline & ${ }^{33} \mathrm{~S}$ & 0.0014 & 0.088 & 0.60 & 1.4 & 2.0 & 2.1 \\
\hline & ${ }^{34} \mathrm{~S}$ & 1.7 & 1.7 & 1.3 & 0.67 & 0.20 & 0.056 \\
\hline & ${ }^{35} \mathrm{Cl}$ & 2.0 & 1.8 & 1.3 & 0.65 & 0.24 & 0.12 \\
\hline & ${ }^{36} \mathrm{Ar}$ & 2.0 & 1.9 & 1.4 & 0.68 & 0.29 & 0.18 \\
\hline \multirow{5}{*}{${ }^{34} \mathrm{~S}(\mathrm{p}, \gamma){ }^{35} \mathrm{Cl}$} & ${ }^{37} \mathrm{Ar}$ & 1.4 & 1.3 & 1.1 & 0.90 & 0.80 & 0.75 \\
\hline & ${ }^{37} \mathrm{Cl}$ & 1.2 & 1.2 & 1.1 & 1.0 & 0.91 & 0.91 \\
\hline & ${ }^{34} \mathrm{~S}$ & 0.017 & 0.18 & 0.67 & 1.3 & 1.6 & 1.7 \\
\hline & ${ }^{35} \mathrm{Cl}$ & 2.2 & 2.0 & 1.4 & 0.64 & 0.22 & 0.092 \\
\hline & ${ }^{36} \mathrm{Ar}$ & 2.3 & 2.0 & 1.4 & 0.67 & 0.27 & 0.14 \\
\hline \multirow{6}{*}{$\left.{ }^{33} \mathrm{Cl}(\mathrm{p}, \gamma)\right)^{34} \mathrm{Ar}$} & ${ }^{37} \mathrm{Ar}$ & 1.4 & 1.3 & 1.1 & 0.90 & 0.70 & 0.65 \\
\hline & ${ }^{37} \mathrm{Cl}$ & 1.2 & 1.2 & 1.1 & 1.0 & 0.91 & 0.88 \\
\hline & ${ }^{33} \mathrm{~S}$ & 0.34 & 0.80 & 1.0 & 1.0 & 1.0 & 1.0 \\
\hline & ${ }^{34} \mathrm{~S}$ & 1.2 & 1.1 & 1.0 & 1.0 & 1.0 & 1.0 \\
\hline & ${ }^{35} \mathrm{Cl}$ & 1.9 & 1.2 & 1.0 & 0.92 & 0.92 & 0.92 \\
\hline & ${ }^{36} \mathrm{Ar}$ & 2.3 & 1.4 & 1.1 & 0.96 & 0.94 & 0.92 \\
\hline \multirow{5}{*}{$\left.{ }^{34} \mathrm{Cl}(\mathrm{p}, \gamma)\right)^{35} \mathrm{Ar}$} & ${ }^{37} \mathrm{Ar}$ & 1.6 & 1.2 & 1.0 & 1.0 & 1.0 & 1.0 \\
\hline & ${ }^{37} \mathrm{Cl}$ & 1.3 & 1.1 & 1.1 & 1.0 & 1.0 & 1.0 \\
\hline & ${ }^{34} \mathrm{~S}$ & 0.43 & 0.83 & 0.94 & 1.0 & 1.0 & 1.0 \\
\hline & ${ }^{35} \mathrm{Cl}$ & 1.6 & 1.2 & 1.0 & 1.0 & 0.92 & 0.92 \\
\hline & ${ }^{36} \mathrm{Ar}$ & 2.0 & 1.3 & 1.1 & 0.97 & 0.94 & 0.94 \\
\hline \multirow{3}{*}{${ }^{35} \mathrm{Cl}(\mathrm{p}, \gamma){ }^{36} \mathrm{Ar}$} & ${ }^{37} \mathrm{Ar}$ & 1.4 & 1.1 & 1.0 & 1.0 & 1.0 & 1.0 \\
\hline & ${ }^{36} \mathrm{Ar}$ & $\ldots$ & $\ldots$ & 1.8 & 0.54 & $\ldots$ & $\cdots$ \\
\hline & ${ }^{37} \mathrm{Ar}$ & $\cdots$ & $\cdots$ & 1.3 & 0.80 & $\ldots$ & $\ldots$ \\
\hline \multirow{3}{*}{${ }^{37} \operatorname{Ar}(\mathrm{p}, \gamma){ }^{38} \mathrm{~K}$} & ${ }^{37} \mathrm{Cl}$ & $\ldots$ & $\ldots$ & 1.2 & 1.0 & $\cdots$ & $\ldots$ \\
\hline & ${ }^{37} \mathrm{Ar}$ & 0.048 & 0.25 & 0.75 & 1.2 & 1.4 & 1.5 \\
\hline & ${ }^{37} \mathrm{Cl}$ & 0.65 & 0.73 & 0.91 & 1.1 & 1.2 & 1.3 \\
\hline
\end{tabular}


Table 5-Continued

\begin{tabular}{|c|c|c|c|c|c|c|c|}
\hline \multirow[t]{2}{*}{ Reaction } & \multirow[t]{2}{*}{ Isotope i } & \multicolumn{6}{|c|}{ Reaction rate multiplied by } \\
\hline & & 100 & 10 & 2 & 0.5 & 0.1 & 0.01 \\
\hline \multirow{6}{*}{${ }^{37} \mathrm{~K}(\mathrm{p}, \gamma){ }^{38} \mathrm{Ca}$} & ${ }^{38} \mathrm{Ar}$ & 2.6 & 2.4 & 1.5 & 0.68 & 0.31 & 0.21 \\
\hline & ${ }^{39} \mathrm{~K}$ & 1.6 & 1.5 & 1.1 & 0.91 & 0.81 & 0.78 \\
\hline & ${ }^{37} \mathrm{Ar}$ & 0.65 & 0.95 & 1.0 & 1.0 & 1.0 & 1.0 \\
\hline & ${ }^{37} \mathrm{Cl}$ & 0.89 & 1.0 & 1.0 & 1.0 & 1.0 & 1.0 \\
\hline & ${ }^{38} \mathrm{Ar}$ & 1.6 & 1.2 & 1.1 & 1.0 & 1.0 & 1.0 \\
\hline & ${ }^{39} \mathrm{~K}$ & 1.3 & 1.0 & 1.0 & 1.0 & 1.0 & 1.0 \\
\hline \multirow[t]{2}{*}{${ }^{38} \operatorname{Ar}(\mathrm{p}, \gamma){ }^{39} \mathrm{~K}$} & ${ }^{38} \mathrm{Ar}$ & 0.79 & 0.85 & 0.91 & 1.1 & 1.2 & 1.2 \\
\hline & ${ }^{39} \mathrm{~K}$ & 1.7 & 1.5 & 1.3 & 0.75 & 0.50 & 0.44 \\
\hline \multirow[t]{2}{*}{${ }^{38} \mathrm{~K}(\mathrm{p}, \gamma){ }^{39} \mathrm{Ca}$} & ${ }^{38} \mathrm{Ar}$ & 0.26 & 0.69 & 1.0 & 1.1 & 1.1 & 1.1 \\
\hline & ${ }^{39} \mathrm{~K}$ & 3.4 & 2.1 & 1.2 & 0.91 & 0.81 & 0.78 \\
\hline \multirow[t]{2}{*}{${ }^{39} \mathrm{~K}(\mathrm{p}, \gamma){ }^{40} \mathrm{Ca}$} & ${ }^{39} \mathrm{~K}$ & 0.041 & 0.34 & 0.84 & 1.1 & 1.2 & 1.2 \\
\hline & ${ }^{40} \mathrm{Ca}$ & 1.2 & 1.1 & 1.1 & 1.0 & 1.0 & 1.0 \\
\hline
\end{tabular}

NOTE.- See $\S 4$ for an explanation of the quantities listed here. 
Table 6. FINAL ABUNDANCE CHANGES X X $_{i, r e c}$ RESULTING FROM REACTION RATE VARIATIONS FOR ONe NOVA MODEL P2 $\left(\mathrm{T}_{P E A K}=0.356 \mathrm{GK}\right)$

\begin{tabular}{|c|c|c|c|c|c|c|c|}
\hline \multirow[t]{2}{*}{ Reaction } & \multirow[t]{2}{*}{ Isotope i } & \multicolumn{6}{|c|}{ Reaction rate multiplied by } \\
\hline & & 100 & 10 & 2 & 0.5 & 0.1 & 0.01 \\
\hline${ }^{3} \mathrm{He}(\alpha, \gamma){ }^{7} \mathrm{Be}$ & ${ }^{7} \mathrm{Be}$ & $\ldots$ & $\cdots$ & 0.26 & 1.7 & $\cdots$ & $\ldots$ \\
\hline${ }^{8} \mathrm{~B}(\mathrm{p}, \gamma)^{9} \mathrm{C}$ & ${ }^{7} \mathrm{Be}$ & $\ldots$ & 0.63 & 0.90 & 1.1 & 1.2 & $\ldots$ \\
\hline \multirow[t]{2}{*}{${ }^{13} \mathrm{~N}(\mathrm{p}, \gamma){ }^{14} \mathrm{O}$} & ${ }^{13} \mathrm{C}$ & $\cdots$ & $\cdots$ & 0.81 & 1.1 & $\cdots$ & $\cdots$ \\
\hline & ${ }^{14} \mathrm{~N}$ & $\cdots$ & $\cdots$ & 1.2 & 0.86 & $\cdots$ & $\ldots$ \\
\hline \multirow[t]{2}{*}{${ }^{15} \mathrm{O}(\alpha, \gamma){ }^{19} \mathrm{Ne}$} & ${ }^{16} \mathrm{O}$ & 1.3 & 1.1 & 1.0 & 1.0 & 1.0 & 1.0 \\
\hline & ${ }^{19} \mathrm{~F}$ & 1.5 & 1.0 & 1.0 & 1.0 & 1.0 & 1.0 \\
\hline${ }^{15} \mathrm{~N}(\mathrm{p}, \gamma){ }^{16} \mathrm{O}$ & ${ }^{16} \mathrm{O}$ & $\ldots$ & $\ldots$ & 1.4 & 0.80 & $\ldots$ & $\ldots$ \\
\hline${ }^{16} \mathrm{O}(\mathrm{p}, \gamma){ }^{17} \mathrm{~F}$ & ${ }^{16} \mathrm{O}$ & $\cdots$ & $\cdots$ & 0.73 & 1.7 & $\cdots$ & $\cdots$ \\
\hline \multirow[t]{4}{*}{${ }^{17} \mathrm{O}(\mathrm{p}, \gamma)^{18} \mathrm{~F}$} & ${ }^{17} \mathrm{O}$ & $\ldots$ & 0.76 & 1.0 & 1.1 & 1.1 & $\cdots$ \\
\hline & ${ }^{18} \mathrm{~F}$ & $\cdots$ & 7.4 & 1.9 & 0.51 & 0.10 & $\cdots$ \\
\hline & ${ }^{18} \mathrm{O}$ & $\ldots$ & 7.5 & 2.0 & 0.51 & 0.11 & $\ldots$ \\
\hline & ${ }^{19} \mathrm{~F}$ & $\ldots$ & 2.5 & 1.2 & 0.85 & 0.75 & $\ldots$ \\
\hline \multirow[t]{5}{*}{${ }^{17} \mathrm{O}(\mathrm{p}, \alpha){ }^{14} \mathrm{~N}$} & ${ }^{14} \mathrm{~N}$ & $\ldots$ & 1.2 & 1.0 & 1.0 & 0.95 & $\ldots$ \\
\hline & ${ }^{17} \mathrm{O}$ & $\cdots$ & 0.47 & 0.88 & 1.1 & 1.3 & $\ldots$ \\
\hline & ${ }^{18} \mathrm{~F}$ & $\cdots$ & 0.44 & 0.84 & 1.1 & 1.3 & $\ldots$ \\
\hline & ${ }^{18} \mathrm{O}$ & $\cdots$ & 0.44 & 0.85 & 1.1 & 1.3 & $\ldots$ \\
\hline & ${ }^{19} \mathrm{~F}$ & $\cdots$ & 0.83 & 0.91 & 1.0 & 1.1 & $\cdots$ \\
\hline \multirow[t]{7}{*}{${ }^{17} \mathrm{~F}(\mathrm{p}, \gamma){ }^{18} \mathrm{Ne}$} & ${ }^{12} \mathrm{C}$ & $\ldots$ & 1.1 & 1.1 & 0.86 & 0.65 & $\cdots$ \\
\hline & ${ }^{13} \mathrm{C}$ & $\cdots$ & 1.0 & 1.1 & 0.85 & 0.63 & $\cdots$ \\
\hline & ${ }^{14} \mathrm{~N}$ & $\cdots$ & 1.1 & 1.1 & 0.91 & 0.73 & $\cdots$ \\
\hline & ${ }^{15} \mathrm{~N}$ & $\cdots$ & 1.1 & 1.1 & 0.87 & 0.65 & $\cdots$ \\
\hline & ${ }^{17} \mathrm{O}$ & $\ldots$ & 0.0018 & 0.24 & 2.1 & 3.9 & $\ldots$ \\
\hline & ${ }^{18} \mathrm{~F}$ & $\cdots$ & 0.0017 & 0.23 & 2.1 & 4.0 & $\cdots$ \\
\hline & ${ }^{18} \mathrm{O}$ & $\cdots$ & 0.0017 & 0.24 & 2.1 & 3.8 & $\cdots$ \\
\hline \multirow[t]{2}{*}{${ }^{18} \mathrm{~F}(\mathrm{p}, \gamma){ }^{19} \mathrm{Ne}$} & ${ }^{16} \mathrm{O}$ & $\cdots$ & 4.4 & 1.4 & 0.80 & 0.67 & $\cdots$ \\
\hline & ${ }^{19} \mathrm{~F}$ & $\cdots$ & 9.1 & 1.9 & 0.50 & 0.12 & $\cdots$ \\
\hline \multirow[t]{4}{*}{${ }^{18} \mathrm{~F}(\mathrm{p}, \alpha){ }^{15} \mathrm{O}$} & ${ }^{16} \mathrm{O}$ & 0.63 & 0.67 & 0.80 & 1.4 & 4.4 & 35 \\
\hline & ${ }^{18} \mathrm{~F}$ & 0.017 & 0.12 & 0.53 & 1.9 & 7.4 & 42 \\
\hline & ${ }^{18} \mathrm{O}$ & 0.017 & 0.12 & 0.54 & 1.8 & 7.5 & 42 \\
\hline & ${ }^{19} \mathrm{~F}$ & 0.015 & 0.10 & 0.49 & 1.9 & 9.1 & 80 \\
\hline${ }^{19} \mathrm{Ne}(\mathrm{p}, \gamma)^{20} \mathrm{Na}$ & ${ }^{19} \mathrm{~F}$ & 0.65 & 0.91 & 1.0 & 1.0 & 1.0 & 1.0 \\
\hline \multirow[t]{14}{*}{${ }^{20} \mathrm{Ne}(\mathrm{p}, \gamma){ }^{21} \mathrm{Na}$} & ${ }^{20} \mathrm{Ne}$ & $\ldots$ & $\cdots$ & 0.74 & 1.4 & $\cdots$ & $\cdots$ \\
\hline & ${ }^{21} \mathrm{Ne}$ & $\ldots$ & $\cdots$ & 1.4 & 0.69 & $\cdots$ & $\cdots$ \\
\hline & ${ }^{22} \mathrm{Na}$ & $\cdots$ & $\cdots$ & 1.4 & 0.71 & $\ldots$ & $\cdots$ \\
\hline & ${ }^{22} \mathrm{Ne}$ & $\ldots$ & $\ldots$ & 1.4 & 0.73 & $\cdots$ & $\cdots$ \\
\hline & ${ }^{23} \mathrm{Na}$ & $\cdots$ & $\cdots$ & 1.2 & 0.70 & $\cdots$ & $\cdots$ \\
\hline & ${ }^{24} \mathrm{Mg}$ & $\cdots$ & $\cdots$ & 1.3 & 0.71 & $\ldots$ & $\ldots$ \\
\hline & ${ }^{25} \mathrm{Mg}$ & $\cdots$ & $\cdots$ & 1.1 & 0.76 & $\cdots$ & $\cdots$ \\
\hline & ${ }^{26} \mathrm{Al}$ & $\cdots$ & $\cdots$ & 1.1 & 0.73 & $\cdots$ & $\cdots$ \\
\hline & ${ }^{26} \mathrm{Mg}$ & $\cdots$ & $\ldots$ & 1.1 & 0.77 & $\cdots$ & $\cdots$ \\
\hline & ${ }^{27} \mathrm{Al}$ & $\ldots$ & $\ldots$ & 1.1 & 0.73 & $\ldots$ & $\ldots$ \\
\hline & ${ }^{28} \mathrm{Si}$ & $\ldots$ & $\cdots$ & 1.1 & 0.76 & $\cdots$ & $\ldots$ \\
\hline & ${ }^{29} \mathrm{Si}$ & $\cdots$ & $\cdots$ & 1.1 & 0.74 & $\cdots$ & $\cdots$ \\
\hline & ${ }^{30} \mathrm{Si}$ & $\cdots$ & $\cdots$ & 1.2 & 0.73 & $\ldots$ & $\ldots$ \\
\hline & ${ }^{31} \mathrm{P}$ & $\cdots$ & $\cdots$ & 1.2 & 0.75 & $\cdots$ & $\cdots$ \\
\hline \multirow[t]{2}{*}{${ }^{21} \mathrm{Na}(\mathrm{p}, \gamma){ }^{22} \mathrm{Mg}$} & ${ }^{21} \mathrm{Ne}$ & 0.18 & 0.49 & 0.82 & 1.2 & 1.7 & 3.2 \\
\hline & ${ }^{22} \mathrm{Na}$ & 0.73 & 0.76 & 0.88 & 1.2 & 1.9 & 4.7 \\
\hline
\end{tabular}


Table 6-Continued

\begin{tabular}{|c|c|c|c|c|c|c|c|}
\hline \multirow[t]{2}{*}{ Reaction } & \multirow[t]{2}{*}{ Isotope i } & \multicolumn{6}{|c|}{ Reaction rate multiplied by } \\
\hline & & 100 & 10 & 2 & 0.5 & 0.1 & 0.01 \\
\hline \multirow{5}{*}{${ }^{22} \mathrm{Na}(\mathrm{p}, \gamma)^{23} \mathrm{Mg}$} & ${ }^{22} \mathrm{Ne}$ & 0.75 & 0.77 & 0.87 & 1.2 & 1.9 & 4.8 \\
\hline & ${ }^{23} \mathrm{Na}$ & 1.0 & 0.98 & 0.98 & 1.0 & 1.1 & 1.6 \\
\hline & ${ }^{24} \mathrm{Mg}$ & 1.0 & 1.0 & 1.0 & 1.0 & 1.1 & 1.5 \\
\hline & ${ }^{22} \mathrm{Na}$ & $\cdots$ & $\cdots$ & 0.61 & 1.7 & $\cdots$ & $\cdots$ \\
\hline & ${ }^{22} \mathrm{Ne}$ & $\ldots$ & $\cdots$ & 0.63 & 1.7 & $\ldots$ & $\cdots$ \\
\hline \multirow[t]{13}{*}{${ }^{23} \mathrm{Na}(\mathrm{p}, \gamma){ }^{24} \mathrm{Mg}$} & ${ }^{20} \mathrm{Ne}$ & $\ldots$ & 0.44 & 0.79 & 1.2 & 1.5 & 1.6 \\
\hline & ${ }^{21} \mathrm{Ne}$ & $\ldots$ & 0.44 & 0.78 & 1.2 & 1.4 & 1.6 \\
\hline & ${ }^{22} \mathrm{Na}$ & $\ldots$ & 0.43 & 0.78 & 1.2 & 1.5 & 1.6 \\
\hline & ${ }^{22} \mathrm{Ne}$ & $\cdots$ & 0.45 & 0.80 & 1.2 & 1.5 & 1.5 \\
\hline & ${ }^{23} \mathrm{Na}$ & $\ldots$ & 0.16 & 0.67 & 1.3 & 1.6 & 1.8 \\
\hline & ${ }^{24} \mathrm{Mg}$ & $\cdots$ & 1.8 & 1.4 & 0.64 & 0.16 & 0.018 \\
\hline & ${ }^{25} \mathrm{Mg}$ & $\ldots$ & 2.1 & 1.4 & 0.65 & 0.20 & 0.060 \\
\hline & ${ }^{26} \mathrm{Al}$ & $\ldots$ & 2.0 & 1.4 & 0.65 & 0.22 & 0.084 \\
\hline & ${ }^{26} \mathrm{Mg}$ & $\ldots$ & 2.0 & 1.4 & 0.65 & 0.21 & 0.077 \\
\hline & ${ }^{27} \mathrm{Al}$ & $\ldots$ & 1.9 & 1.3 & 0.67 & 0.28 & 0.16 \\
\hline & ${ }^{28} \mathrm{Si}$ & $\ldots$ & 1.5 & 1.2 & 0.83 & 0.59 & 0.51 \\
\hline & ${ }^{29} \mathrm{Si}$ & $\ldots$ & 1.3 & 1.1 & 0.89 & 0.74 & 0.67 \\
\hline & ${ }^{30} \mathrm{Si}$ & $\cdots$ & 1.0 & 1.0 & 1.0 & 1.0 & 0.81 \\
\hline \multirow[t]{11}{*}{${ }^{23} \mathrm{Na}(\mathrm{p}, \alpha){ }^{20} \mathrm{Ne}$} & ${ }^{20} \mathrm{Ne}$ & $\ldots$ & $\ldots$ & 1.2 & 0.79 & $\cdots$ & $\cdots$ \\
\hline & ${ }^{21} \mathrm{Ne}$ & $\cdots$ & $\cdots$ & 1.2 & 0.78 & $\cdots$ & $\cdots$ \\
\hline & ${ }^{22} \mathrm{Na}$ & $\ldots$ & $\ldots$ & 1.2 & 0.78 & $\ldots$ & $\ldots$ \\
\hline & ${ }^{22} \mathrm{Ne}$ & $\ldots$ & $\cdots$ & 1.2 & 0.77 & $\cdots$ & $\cdots$ \\
\hline & ${ }^{23} \mathrm{Na}$ & $\ldots$ & $\ldots$ & 0.54 & 1.6 & & \\
\hline & ${ }^{24} \mathrm{Mg}$ & $\cdots$ & $\cdots$ & 0.57 & 1.6 & $\cdots$ & $\cdots$ \\
\hline & ${ }^{25} \mathrm{Mg}$ & $\ldots$ & $\ldots$ & 0.65 & 1.4 & $\cdots$ & $\cdots$ \\
\hline & ${ }^{26} \mathrm{Al}$ & $\ldots$ & $\cdots$ & 0.65 & 1.4 & $\ldots$ & $\ldots$ \\
\hline & ${ }^{26} \mathrm{Mg}$ & $\cdots$ & $\cdots$ & 0.67 & 1.4 & $\cdots$ & $\cdots$ \\
\hline & ${ }^{27} \mathrm{Al}$ & $\ldots$ & $\cdots$ & 0.67 & 1.3 & $\cdots$ & $\cdots$ \\
\hline & ${ }^{28} \mathrm{Si}$ & $\cdots$ & $\cdots$ & 0.83 & 1.2 & $\cdots$ & $\cdots$ \\
\hline \multirow[t]{16}{*}{${ }^{23} \mathrm{Mg}(\mathrm{p}, \gamma)^{24} \mathrm{Al}$} & ${ }^{20} \mathrm{Ne}$ & 0.38 & 0.57 & 0.85 & 1.2 & 1.4 & 1.5 \\
\hline & ${ }^{21} \mathrm{Ne}$ & 0.38 & 0.57 & 0.84 & 1.1 & 1.4 & 1.4 \\
\hline & ${ }^{22} \mathrm{Na}$ & 0.37 & 0.57 & 0.84 & 1.2 & 1.4 & 1.5 \\
\hline & ${ }^{22} \mathrm{Ne}$ & 0.38 & 0.58 & 0.85 & 1.2 & 1.4 & 1.5 \\
\hline & ${ }^{23} \mathrm{Na}$ & 0.23 & 0.51 & 0.84 & 1.1 & 1.4 & 1.4 \\
\hline & ${ }^{24} \mathrm{Mg}$ & 0.23 & 0.54 & 0.86 & 1.1 & 1.4 & 1.4 \\
\hline & ${ }^{25} \mathrm{Mg}$ & 0.40 & 0.57 & 0.85 & 1.1 & 1.3 & 1.4 \\
\hline & ${ }^{26} \mathrm{Al}$ & 0.54 & 0.65 & 0.86 & 1.1 & 1.3 & 1.4 \\
\hline & ${ }^{26} \mathrm{Mg}$ & 0.49 & 0.60 & 0.86 & 1.1 & 1.3 & 1.4 \\
\hline & ${ }^{27} \mathrm{Al}$ & 0.80 & 0.80 & 0.87 & 1.1 & 1.3 & 1.3 \\
\hline & ${ }^{28} \mathrm{Si}$ & 1.5 & 1.2 & 1.1 & 0.96 & 0.93 & 0.91 \\
\hline & ${ }^{29} \mathrm{Si}$ & 1.6 & 1.4 & 1.1 & 0.89 & 0.74 & 0.70 \\
\hline & ${ }^{30} \mathrm{Si}$ & 1.7 & 1.5 & 1.2 & 0.85 & 0.62 & 0.50 \\
\hline & ${ }^{31} \mathrm{P}$ & 1.5 & 1.4 & 1.2 & 0.83 & 0.54 & 0.46 \\
\hline & ${ }^{32} \mathrm{~S}$ & 1.2 & 1.2 & 1.1 & 0.88 & 0.71 & 0.65 \\
\hline & ${ }^{33} \mathrm{~S}$ & 1.0 & 1.0 & 1.0 & 1.0 & 1.0 & 0.78 \\
\hline \multirow[t]{2}{*}{${ }^{25} \mathrm{Mg}(\mathrm{p}, \gamma)^{26} \mathrm{Al}^{g}$} & ${ }^{25} \mathrm{Mg}$ & $\cdots$ & $\cdots$ & 0.64 & 1.4 & $\cdots$ & $\cdots$ \\
\hline & ${ }^{26} \mathrm{Al}$ & $\ldots$ & $\ldots$ & 1.2 & 0.73 & $\ldots$ & $\ldots$ \\
\hline
\end{tabular}


Table 6-Continued

\begin{tabular}{|c|c|c|c|c|c|c|c|}
\hline \multirow[t]{2}{*}{ Reaction } & \multirow[t]{2}{*}{ Isotope $\mathrm{i}$} & \multicolumn{6}{|c|}{ Reaction rate multiplied by } \\
\hline & & 100 & 10 & 2 & 0.5 & 0.1 & 0.01 \\
\hline & ${ }^{26} \mathrm{Mg}$ & $\cdots$ & $\cdots$ & 0.63 & 1.5 & $\cdots$ & $\cdots$ \\
\hline${ }^{25} \mathrm{Mg}(\mathrm{p}, \gamma){ }^{26} \mathrm{Al}^{m}$ & ${ }^{26} \mathrm{Mg}$ & $\ldots$ & $\ldots$ & 1.8 & 0.53 & $\ldots$ & $\ldots$ \\
\hline${ }^{26} \mathrm{Mg}(\mathrm{p}, \gamma){ }^{27} \mathrm{Al}$ & ${ }^{26} \mathrm{Mg}$ & $\ldots$ & $\cdots$ & 0.60 & 1.5 & $\cdots$ & $\cdots$ \\
\hline \multirow[t]{6}{*}{${ }^{25} \mathrm{Al}(\mathrm{p}, \gamma){ }^{26} \mathrm{Si}$} & ${ }^{25} \mathrm{Mg}$ & 0.70 & 0.89 & 0.97 & 1.0 & 1.1 & 1.1 \\
\hline & ${ }^{26} \mathrm{Al}$ & 0.57 & 0.81 & 0.95 & 1.0 & 1.1 & 1.2 \\
\hline & ${ }^{27} \mathrm{Al}$ & 0.63 & 0.73 & 0.93 & 1.1 & 1.2 & 1.3 \\
\hline & ${ }^{28} \mathrm{Si}$ & 1.0 & 0.94 & 0.96 & 1.1 & 1.3 & 1.5 \\
\hline & ${ }^{29} \mathrm{Si}$ & 1.0 & 1.0 & 1.0 & 1.0 & 1.0 & 1.4 \\
\hline & ${ }^{32} \mathrm{~S}$ & 1.0 & 1.0 & 1.0 & 0.94 & 0.82 & 0.71 \\
\hline${ }^{26} \mathrm{Al}^{g}(\mathrm{p}, \gamma)^{27} \mathrm{Si}$ & ${ }^{26} \mathrm{Al}$ & $\ldots$ & 0.054 & 0.46 & 1.9 & $\cdots$ & $\cdots$ \\
\hline${ }^{26} \mathrm{Al}^{m}(\mathrm{p}, \gamma)^{27} \mathrm{Si}$ & ${ }^{26} \mathrm{Mg}$ & 0.095 & 0.42 & 0.81 & 1.2 & 1.4 & 1.7 \\
\hline \multirow[t]{3}{*}{${ }^{28} \mathrm{Si}(\mathrm{p}, \gamma){ }^{29} \mathrm{P}$} & ${ }^{28} \mathrm{Si}$ & $\ldots$ & $\ldots$ & 0.79 & 1.3 & $\cdots$ & $\ldots$ \\
\hline & ${ }^{29} \mathrm{Si}$ & $\ldots$ & $\ldots$ & 1.4 & 0.70 & $\ldots$ & $\cdots$ \\
\hline & ${ }^{30} \mathrm{Si}$ & $\ldots$ & $\ldots$ & 1.2 & 0.81 & $\ldots$ & $\ldots$ \\
\hline \multirow[t]{2}{*}{${ }^{29} \mathrm{Si}(\mathrm{p}, \gamma){ }^{30} \mathrm{P}$} & ${ }^{29} \mathrm{Si}$ & $\ldots$ & 0.078 & 0.48 & 1.9 & 6.7 & $\ldots$ \\
\hline & ${ }^{30} \mathrm{Si}$ & $\ldots$ & 1.1 & 1.0 & 0.96 & 0.77 & $\ldots$ \\
\hline \multirow[t]{10}{*}{${ }^{29} \mathrm{P}(\mathrm{p}, \gamma){ }^{30} \mathrm{~S}$} & ${ }^{29} \mathrm{Si}$ & 0.48 & 0.78 & 0.96 & 1.0 & 1.1 & 1.1 \\
\hline & ${ }^{30} \mathrm{Si}$ & 0.62 & 0.73 & 0.92 & 1.1 & 1.3 & 1.3 \\
\hline & ${ }^{31} \mathrm{P}$ & 0.79 & 0.79 & 0.92 & 1.1 & 1.3 & 1.3 \\
\hline & ${ }^{35} \mathrm{Cl}$ & 1.2 & 1.2 & 1.1 & 0.89 & 0.72 & 0.66 \\
\hline & ${ }^{36} \mathrm{Ar}$ & 1.3 & 1.3 & 1.1 & 0.88 & 0.69 & 0.63 \\
\hline & ${ }^{37} \mathrm{Ar}$ & 1.4 & 1.3 & 1.1 & 0.87 & 0.69 & 0.62 \\
\hline & ${ }^{37} \mathrm{Cl}$ & 1.4 & 1.3 & 1.2 & 0.92 & 0.71 & 0.64 \\
\hline & ${ }^{38} \mathrm{Ar}$ & 1.5 & 1.4 & 1.1 & 0.86 & 0.67 & 0.62 \\
\hline & ${ }^{39} \mathrm{~K}$ & 1.6 & 1.5 & 1.2 & 0.90 & 0.75 & 0.70 \\
\hline & ${ }^{40} \mathrm{Ca}$ & 1.4 & 1.3 & 1.1 & 0.95 & 0.88 & 0.84 \\
\hline \multirow[t]{12}{*}{${ }^{30} \mathrm{P}(\mathrm{p}, \gamma){ }^{31} \mathrm{~S}$} & ${ }^{30} \mathrm{Si}$ & 0.015 & 0.15 & 0.62 & 1.6 & 3.7 & 7.7 \\
\hline & ${ }^{31} \mathrm{P}$ & 1.4 & 1.3 & 1.1 & 0.88 & 0.50 & 0.19 \\
\hline & ${ }^{32} \mathrm{~S}$ & 1.1 & 1.1 & 1.0 & 0.94 & 0.71 & 0.21 \\
\hline & ${ }^{33} \mathrm{~S}$ & 1.1 & 1.1 & 1.0 & 0.97 & 0.72 & 0.21 \\
\hline & ${ }^{34} \mathrm{~S}$ & 1.0 & 1.0 & 1.0 & 0.98 & 0.71 & 0.20 \\
\hline & ${ }^{35} \mathrm{Cl}$ & 1.0 & 1.0 & 1.0 & 0.96 & 0.71 & 0.20 \\
\hline & ${ }^{36} \mathrm{Ar}$ & 1.1 & 1.1 & 1.1 & 0.94 & 0.69 & 0.19 \\
\hline & ${ }^{37} \mathrm{Ar}$ & 1.1 & 1.0 & 1.0 & 0.95 & 0.67 & 0.18 \\
\hline & ${ }^{37} \mathrm{Cl}$ & 1.1 & 1.1 & 1.1 & 1.0 & 0.68 & 0.19 \\
\hline & ${ }^{38} \mathrm{Ar}$ & 1.0 & 1.0 & 1.0 & 0.95 & 0.62 & 0.19 \\
\hline & ${ }^{39} \mathrm{~K}$ & 1.1 & 1.1 & 1.1 & 0.95 & 0.65 & 0.23 \\
\hline & ${ }^{40} \mathrm{Ca}$ & 1.1 & 1.0 & 1.1 & 0.96 & 0.81 & 0.61 \\
\hline \multirow[t]{9}{*}{${ }^{31} \mathrm{P}(\mathrm{p}, \alpha){ }^{28} \mathrm{Si}$} & ${ }^{28} \mathrm{Si}$ & $\ldots$ & 1.6 & 1.1 & 0.95 & $\ldots$ & $\ldots$ \\
\hline & ${ }^{29} \mathrm{Si}$ & $\ldots$ & 1.9 & 1.1 & 0.93 & $\cdots$ & $\ldots$ \\
\hline & ${ }^{30} \mathrm{Si}$ & $\ldots$ & 1.8 & 1.2 & 0.92 & $\ldots$ & $\ldots$ \\
\hline & ${ }^{32} \mathrm{~S}$ & $\ldots$ & 0.57 & 0.88 & 1.0 & $\ldots$ & $\ldots$ \\
\hline & ${ }^{33} \mathrm{~S}$ & $\ldots$ & 0.50 & 0.91 & 1.1 & $\ldots$ & $\ldots$ \\
\hline & ${ }^{34} \mathrm{~S}$ & $\ldots$ & 0.48 & 0.90 & 1.1 & $\ldots$ & $\ldots$ \\
\hline & ${ }^{35} \mathrm{Cl}$ & $\ldots$ & 0.46 & 0.89 & 1.0 & $\ldots$ & $\ldots$ \\
\hline & ${ }^{36} \mathrm{Ar}$ & $\ldots$ & 0.46 & 0.88 & 1.1 & $\ldots$ & $\ldots$ \\
\hline & ${ }^{37} \mathrm{Ar}$ & $\ldots$ & 0.44 & 0.87 & 1.1 & $\ldots$ & $\ldots$ \\
\hline
\end{tabular}


Table 6-Continued

\begin{tabular}{|c|c|c|c|c|c|c|c|}
\hline \multirow[t]{2}{*}{ Reaction } & \multirow[t]{2}{*}{ Isotope i } & \multicolumn{6}{|c|}{ Reaction rate multiplied by } \\
\hline & & 100 & 10 & 2 & 0.5 & 0.1 & 0.01 \\
\hline \multirow{9}{*}{${ }^{32} \mathrm{~S}(\mathrm{p}, \gamma)^{33} \mathrm{Cl}$} & ${ }^{37} \mathrm{Cl}$ & $\cdots$ & 0.46 & 0.92 & 1.1 & $\cdots$ & $\ldots$ \\
\hline & ${ }^{38} \mathrm{Ar}$ & $\ldots$ & 0.44 & 0.86 & 1.1 & $\ldots$ & $\ldots$ \\
\hline & ${ }^{39} \mathrm{~K}$ & $\ldots$ & 0.48 & 0.90 & 1.1 & $\ldots$ & $\ldots$ \\
\hline & ${ }^{40} \mathrm{Ca}$ & $\ldots$ & 0.74 & 0.95 & 1.1 & $\ldots$ & $\ldots$ \\
\hline & ${ }^{33} \mathrm{~S}$ & $\cdots$ & $\cdots$ & 1.7 & 0.56 & $\cdots$ & $\cdots$ \\
\hline & ${ }^{34} \mathrm{~S}$ & $\ldots$ & $\ldots$ & 1.7 & 0.55 & $\cdots$ & $\cdots$ \\
\hline & ${ }^{35} \mathrm{Cl}$ & $\ldots$ & $\ldots$ & 1.6 & 0.56 & $\cdots$ & $\cdots$ \\
\hline & ${ }^{36} \mathrm{Ar}$ & $\ldots$ & $\ldots$ & 1.7 & 0.56 & $\ldots$ & $\cdots$ \\
\hline & ${ }^{37} \mathrm{Ar}$ & $\ldots$ & $\cdots$ & 1.7 & 0.56 & $\cdots$ & $\cdots$ \\
\hline \multirow{9}{*}{${ }^{33} \mathrm{~S}(\mathrm{p}, \gamma){ }^{34} \mathrm{Cl}$} & ${ }^{37} \mathrm{Cl}$ & $\cdots$ & $\cdots$ & 1.7 & 0.58 & $\ldots$ & $\ldots$ \\
\hline & ${ }^{38} \mathrm{Ar}$ & $\ldots$ & $\ldots$ & 1.7 & 0.57 & $\ldots$ & $\ldots$ \\
\hline & ${ }^{39} \mathrm{~K}$ & & $\cdots$ & 1.8 & 0.60 & $\cdots$ & $\ldots$ \\
\hline & ${ }^{40} \mathrm{Ca}$ & $\ldots$ & $\ldots$ & 1.4 & 0.79 & $\cdots$ & $\ldots$ \\
\hline & ${ }^{33} \mathrm{~S}$ & 0.0010 & 0.059 & 0.50 & 1.8 & 4.1 & 5.6 \\
\hline & ${ }^{34} \mathrm{~S}$ & 1.1 & 1.1 & 1.1 & 0.86 & 0.43 & 0.15 \\
\hline & ${ }^{35} \mathrm{Cl}$ & 1.1 & 1.1 & 1.1 & 0.88 & 0.55 & 0.31 \\
\hline & ${ }^{36} \mathrm{Ar}$ & 1.2 & 1.1 & 1.1 & 0.88 & 0.59 & 0.37 \\
\hline & ${ }^{37} \mathrm{Ar}$ & 1.1 & 1.1 & 1.1 & 0.91 & 0.64 & 0.44 \\
\hline \multirow{9}{*}{${ }^{34} \mathrm{~S}(\mathrm{p}, \gamma){ }^{35} \mathrm{Cl}$} & ${ }^{37} \mathrm{Cl}$ & 1.2 & 1.2 & 1.1 & 0.92 & 0.66 & 0.46 \\
\hline & ${ }^{38} \mathrm{Ar}$ & 1.1 & 1.1 & 1.0 & 0.90 & 0.67 & 0.48 \\
\hline & ${ }^{39} \mathrm{~K}$ & 1.2 & 1.1 & 1.1 & 0.95 & 0.75 & 0.55 \\
\hline & ${ }^{40} \mathrm{Ca}$ & 1.0 & 1.0 & 1.0 & 1.0 & 1.0 & 0.77 \\
\hline & ${ }^{34} \mathrm{~S}$ & 0.01 & 0.12 & 0.57 & 1.6 & 3.1 & 3.8 \\
\hline & ${ }^{35} \mathrm{Cl}$ & 1.2 & 1.2 & 1.1 & 0.85 & 0.48 & 0.30 \\
\hline & ${ }^{36} \mathrm{Ar}$ & 1.3 & 1.3 & 1.1 & 0.88 & 0.55 & 0.37 \\
\hline & ${ }^{37} \mathrm{Ar}$ & 1.2 & 1.2 & 1.1 & 0.89 & 0.62 & 0.45 \\
\hline & ${ }^{37} \mathrm{Cl}$ & 1.3 & 1.2 & 1.1 & 0.92 & 0.63 & 0.48 \\
\hline \multirow{7}{*}{${ }^{33} \mathrm{Cl}(\mathrm{p}, \gamma){ }^{34} \mathrm{Ar}$} & ${ }^{38} \mathrm{Ar}$ & 1.1 & 1.1 & 1.0 & 0.90 & 0.67 & 0.52 \\
\hline & ${ }^{39} \mathrm{~K}$ & 1.1 & 1.1 & 1.1 & 0.95 & 0.70 & 0.55 \\
\hline & ${ }^{40} \mathrm{Ca}$ & 1.0 & 1.0 & 1.0 & 1.0 & 1.0 & 0.75 \\
\hline & ${ }^{33} \mathrm{~S}$ & 0.13 & 0.50 & 0.88 & 1.1 & 1.2 & 1.2 \\
\hline & ${ }^{34} \mathrm{~S}$ & 0.67 & 0.74 & 0.93 & 1.1 & 1.1 & 1.2 \\
\hline & ${ }^{37} \mathrm{Ar}$ & 1.4 & 1.3 & 1.1 & 0.93 & 0.85 & 0.84 \\
\hline & ${ }^{37} \mathrm{Cl}$ & 1.4 & 1.3 & 1.2 & 1.0 & 0.92 & 0.83 \\
\hline \multirow{5}{*}{${ }^{34} \mathrm{Cl}(\mathrm{p}, \gamma){ }^{35} \mathrm{Ar}$} & ${ }^{38} \mathrm{Ar}$ & 1.5 & 1.4 & 1.1 & 0.90 & 0.81 & 0.76 \\
\hline & ${ }^{39} \mathrm{~K}$ & 1.6 & 1.5 & 1.3 & 0.90 & 0.80 & 0.75 \\
\hline & ${ }^{40} \mathrm{Ca}$ & 1.4 & 1.3 & 1.1 & 0.95 & 0.88 & 0.86 \\
\hline & ${ }^{34} \mathrm{~S}$ & 0.23 & 0.62 & 0.90 & 1.1 & 1.1 & 1.2 \\
\hline & ${ }^{36} \mathrm{Ar}$ & 1.3 & 1.1 & 1.1 & 1.0 & 1.0 & 1.0 \\
\hline \multirow[t]{6}{*}{$\left.{ }^{35} \mathrm{Cl}(\mathrm{p}, \gamma)\right)^{36} \mathrm{Ar}$} & ${ }^{35} \mathrm{Cl}$ & $\cdots$ & $\cdots$ & 0.70 & 1.3 & $\cdots$ & $\cdots$ \\
\hline & ${ }^{36} \mathrm{Ar}$ & $\cdots$ & $\cdots$ & 1.4 & 0.69 & $\cdots$ & $\cdots$ \\
\hline & ${ }^{37} \mathrm{Ar}$ & $\cdots$ & $\ldots$ & 1.3 & 0.67 & $\cdots$ & $\cdots$ \\
\hline & ${ }^{37} \mathrm{Cl}$ & $\cdots$ & $\ldots$ & 1.4 & 0.69 & $\ldots$ & $\ldots$ \\
\hline & ${ }^{38} \mathrm{Ar}$ & $\cdots$ & $\ldots$ & 1.3 & 0.67 & $\ldots$ & $\cdots$ \\
\hline & ${ }^{39} \mathrm{~K}$ & $\cdots$ & $\ldots$ & 1.3 & 0.75 & $\cdots$ & $\ldots$ \\
\hline \multirow[t]{2}{*}{${ }^{35} \mathrm{Cl}(\mathrm{p}, \alpha)^{32} \mathrm{~S}$} & ${ }^{35} \mathrm{Cl}$ & $\cdots$ & 0.81 & 0.98 & 1.0 & 1.0 & 1.0 \\
\hline & ${ }^{36} \mathrm{Ar}$ & $\cdots$ & 0.81 & 1.0 & 1.0 & 1.1 & 1.1 \\
\hline
\end{tabular}


Table 6-Continued

\begin{tabular}{|c|c|c|c|c|c|c|c|}
\hline \multirow[t]{2}{*}{ Reaction } & \multirow[t]{2}{*}{ Isotope i } & \multicolumn{6}{|c|}{ Reaction rate multiplied by } \\
\hline & & 100 & 10 & 2 & 0.5 & 0.1 & 0.01 \\
\hline \multirow{9}{*}{${ }^{37} \operatorname{Ar}(\mathrm{p}, \gamma){ }^{38} \mathrm{~K}$} & ${ }^{37} \mathrm{Ar}$ & $\cdots$ & 0.80 & 0.96 & 1.0 & 1.0 & 1.0 \\
\hline & ${ }^{37} \mathrm{Cl}$ & $\cdots$ & 0.82 & 1.0 & 1.0 & 1.1 & 1.0 \\
\hline & ${ }^{38} \mathrm{Ar}$ & $\ldots$ & 0.76 & 0.95 & 1.0 & 1.0 & 1.0 \\
\hline & ${ }^{39} \mathrm{~K}$ & $\cdots$ & 0.80 & 1.0 & 1.1 & 1.1 & 1.1 \\
\hline & ${ }^{37} \mathrm{Ar}$ & 0.040 & 0.31 & 0.78 & 1.1 & 1.3 & 1.4 \\
\hline & ${ }^{37} \mathrm{Cl}$ & 0.041 & 0.32 & 0.81 & 1.2 & 1.3 & 1.4 \\
\hline & ${ }^{38} \mathrm{Ar}$ & 3.3 & 2.7 & 1.5 & 0.62 & 0.18 & 0.062 \\
\hline & ${ }^{39} \mathrm{~K}$ & 3.0 & 2.6 & 1.5 & 0.65 & 0.24 & 0.11 \\
\hline & ${ }^{40} \mathrm{Ca}$ & 1.9 & 1.7 & 1.2 & 0.81 & 0.54 & 0.47 \\
\hline \multirow[t]{5}{*}{${ }^{37} \mathrm{~K}(\mathrm{p}, \gamma){ }^{38} \mathrm{Ca}$} & ${ }^{37} \mathrm{Ar}$ & 0.58 & 0.91 & 0.98 & 1.0 & 1.0 & 1.0 \\
\hline & ${ }^{37} \mathrm{Cl}$ & 0.59 & 0.92 & 1.0 & 1.0 & 1.0 & 1.0 \\
\hline & ${ }^{38} \mathrm{Ar}$ & 1.9 & 1.2 & 1.0 & 0.95 & 0.95 & 0.95 \\
\hline & ${ }^{39} \mathrm{~K}$ & 2.6 & 1.4 & 1.1 & 1.0 & 0.95 & 0.95 \\
\hline & ${ }^{40} \mathrm{Ca}$ & 2.1 & 1.4 & 1.1 & 0.98 & 0.95 & 0.95 \\
\hline \multirow[t]{3}{*}{${ }^{38} \mathrm{~K}(\mathrm{p}, \gamma){ }^{39} \mathrm{Ca}$} & ${ }^{38} \mathrm{Ar}$ & 0.11 & 0.57 & 0.90 & 1.0 & 1.0 & 1.1 \\
\hline & ${ }^{39} \mathrm{~K}$ & 9.5 & 5.0 & 1.8 & 0.55 & 0.17 & 0.070 \\
\hline & ${ }^{40} \mathrm{Ca}$ & 5.1 & 3.2 & 1.4 & 0.72 & 0.46 & 0.40 \\
\hline \multirow[t]{2}{*}{${ }^{39} \mathrm{~K}(\mathrm{p}, \gamma){ }^{40} \mathrm{Ca}$} & ${ }^{39} \mathrm{~K}$ & 0.080 & 0.48 & 0.90 & 1.1 & 1.2 & 1.2 \\
\hline & ${ }^{40} \mathrm{Ca}$ & 4.4 & 3.0 & 1.4 & 0.70 & 0.39 & 0.30 \\
\hline
\end{tabular}

NOTE.- See $\S 4$ for an explanation of the quantities listed here. 
Table 7. FINAL ABUNDANCE CHANGES X X $_{i, r e c}$ RESULTING FROM REACTION RATE VARIATIONS FOR ONe NOVA MODEL S1 $\left(\mathrm{T}_{P E A K}=0.418 \mathrm{GK}\right)$

\begin{tabular}{|c|c|c|c|c|c|c|c|}
\hline \multirow[t]{2}{*}{ Reaction } & \multirow[t]{2}{*}{ Isotope i } & \multicolumn{6}{|c|}{ Reaction rate multiplied by } \\
\hline & & 100 & 10 & 2 & 0.5 & 0.1 & 0.01 \\
\hline${ }^{3} \mathrm{He}(\alpha, \gamma){ }^{7} \mathrm{Be}$ & ${ }^{7} \mathrm{Be}$ & $\cdots$ & $\cdots$ & 0.27 & 1.8 & $\cdots$ & $\cdots$ \\
\hline${ }^{7} \mathrm{Be}(\alpha, \gamma){ }^{11} \mathrm{C}$ & ${ }^{7} \mathrm{Be}$ & $\ldots$ & $\ldots$ & 0.39 & 1.6 & $\ldots$ & $\ldots$ \\
\hline${ }^{8} \mathrm{~B}(\mathrm{p}, \gamma)^{9} \mathrm{C}$ & ${ }^{7} \mathrm{Be}$ & $\ldots$ & 0.043 & 0.57 & 1.4 & 2.0 & $\ldots$ \\
\hline \multirow[t]{2}{*}{${ }^{13} \mathrm{~N}(\mathrm{p}, \gamma)^{14} \mathrm{O}$} & ${ }^{13} \mathrm{C}$ & $\cdots$ & $\ldots$ & 0.77 & 1.2 & $\cdots$ & $\cdots$ \\
\hline & ${ }^{14} \mathrm{~N}$ & $\ldots$ & $\cdots$ & 1.2 & 0.86 & $\cdots$ & $\cdots$ \\
\hline \multirow[t]{5}{*}{${ }^{15} \mathrm{O}(\alpha, \gamma){ }^{19} \mathrm{Ne}$} & ${ }^{16} \mathrm{O}$ & 6.6 & 1.5 & 1.0 & 0.92 & 0.92 & 0.92 \\
\hline & ${ }^{17} \mathrm{O}$ & 2.6 & 1.2 & 1.0 & 1.0 & 0.96 & 0.96 \\
\hline & ${ }^{18} \mathrm{~F}$ & 2.7 & 1.2 & 1.1 & 1.0 & 1.0 & 1.0 \\
\hline & ${ }^{18} \mathrm{O}$ & 2.6 & 1.2 & 1.0 & 1.0 & 1.0 & 1.0 \\
\hline & ${ }^{19} \mathrm{~F}$ & 11 & 1.9 & 1.1 & 0.96 & 0.92 & 0.92 \\
\hline${ }^{15} \mathrm{~N}(\mathrm{p}, \gamma){ }^{16} \mathrm{O}$ & ${ }^{16} \mathrm{O}$ & $\ldots$ & $\ldots$ & 1.3 & 0.78 & $\ldots$ & $\ldots$ \\
\hline${ }^{16} \mathrm{O}(\mathrm{p}, \gamma){ }^{17} \mathrm{~F}$ & ${ }^{16} \mathrm{O}$ & $\cdots$ & $\cdots$ & 0.78 & 1.2 & $\cdots$ & $\cdots$ \\
\hline \multirow{3}{*}{${ }^{17} \mathrm{O}(\mathrm{p}, \gamma)^{18} \mathrm{~F}$} & ${ }^{17} \mathrm{O}$ & $\cdots$ & 0.85 & 0.96 & 1.0 & 1.0 & $\cdots$ \\
\hline & ${ }^{18} \mathrm{~F}$ & $\cdots$ & 8.0 & 2.0 & 0.54 & 0.12 & $\cdots$ \\
\hline & ${ }^{18} \mathrm{O}$ & $\cdots$ & 7.8 & 1.9 & 0.52 & 0.11 & $\ldots$ \\
\hline \multirow[t]{3}{*}{${ }^{17} \mathrm{O}(\mathrm{p}, \alpha)^{14} \mathrm{~N}$} & ${ }^{17} \mathrm{O}$ & $\cdots$ & 0.65 & 0.88 & 1.1 & 1.2 & $\cdots$ \\
\hline & ${ }^{18} \mathrm{~F}$ & $\ldots$ & 0.55 & 0.90 & 1.2 & 1.4 & $\ldots$ \\
\hline & ${ }^{18} \mathrm{O}$ & $\ldots$ & 0.54 & 0.87 & 1.1 & 1.4 & $\ldots$ \\
\hline \multirow[t]{9}{*}{${ }^{17} \mathrm{~F}(\mathrm{p}, \gamma){ }^{18} \mathrm{Ne}$} & ${ }^{12} \mathrm{C}$ & $\cdots$ & 0.98 & 1.0 & 0.98 & 0.70 & $\ldots$ \\
\hline & ${ }^{13} \mathrm{C}$ & $\cdots$ & 1.0 & 1.0 & 1.0 & 0.72 & $\cdots$ \\
\hline & ${ }^{14} \mathrm{~N}$ & $\ldots$ & 1.0 & 1.0 & 1.0 & 0.73 & $\cdots$ \\
\hline & ${ }^{15} \mathrm{~N}$ & $\ldots$ & 1.0 & 1.0 & 0.98 & 0.71 & $\ldots$ \\
\hline & ${ }^{16} \mathrm{O}$ & $\cdots$ & 0.92 & 0.92 & 1.2 & 3.1 & $\cdots$ \\
\hline & ${ }^{17} \mathrm{O}$ & $\ldots$ & 0.10 & 0.16 & 16 & 180 & $\ldots$ \\
\hline & ${ }^{18} \mathrm{~F}$ & $\cdots$ & 0.11 & 0.16 & 16 & 180 & $\ldots$ \\
\hline & ${ }^{18} \mathrm{O}$ & $\cdots$ & 0.11 & 0.16 & 16 & 180 & $\cdots$ \\
\hline & ${ }^{19} \mathrm{~F}$ & $\ldots$ & 0.94 & 0.99 & 1.0 & 0.63 & $\ldots$ \\
\hline \multirow[t]{5}{*}{${ }^{18} \mathrm{~F}(\mathrm{p}, \gamma){ }^{19} \mathrm{Ne}$} & ${ }^{16} \mathrm{O}$ & $\ldots$ & 5.7 & 1.5 & 0.70 & 0.48 & $\ldots$ \\
\hline & ${ }^{17} \mathrm{O}$ & $\ldots$ & 2.3 & 1.2 & 0.92 & 0.85 & $\ldots$ \\
\hline & ${ }^{18} \mathrm{~F}$ & $\ldots$ & 2.5 & 1.2 & 1.0 & 0.90 & $\ldots$ \\
\hline & ${ }^{18} \mathrm{O}$ & $\ldots$ & 2.4 & 1.2 & 0.91 & 0.87 & $\cdots$ \\
\hline & ${ }^{19} \mathrm{~F}$ & $\ldots$ & 9.2 & 1.9 & 0.56 & 0.19 & $\cdots$ \\
\hline \multirow[t]{5}{*}{${ }^{18} \mathrm{~F}(\mathrm{p}, \alpha){ }^{15} \mathrm{O}$} & ${ }^{16} \mathrm{O}$ & 0.44 & 0.48 & 0.70 & 1.5 & 5.7 & 49 \\
\hline & ${ }^{17} \mathrm{O}$ & 0.85 & 0.85 & 0.92 & 1.2 & 2.3 & 15 \\
\hline & ${ }^{18} \mathrm{~F}$ & 0.015 & 0.12 & 0.52 & 2.2 & 16 & 480 \\
\hline & ${ }^{18} \mathrm{O}$ & 0.014 & 0.11 & 0.50 & 2.1 & 16 & 460 \\
\hline & ${ }^{19} \mathrm{~F}$ & 0.11 & 0.19 & 0.56 & 1.9 & 9.2 & 85 \\
\hline \multirow[t]{2}{*}{${ }^{19} \mathrm{Ne}(\mathrm{p}, \gamma){ }^{20} \mathrm{Na}$} & ${ }^{16} \mathrm{O}$ & 0.47 & 0.67 & 0.92 & 1.0 & 1.0 & 1.1 \\
\hline & ${ }^{19} \mathrm{~F}$ & 0.15 & 0.51 & 0.90 & 1.1 & 1.1 & 1.2 \\
\hline \multirow[t]{3}{*}{${ }^{20} \mathrm{Ne}(\mathrm{p}, \gamma){ }^{21} \mathrm{Na}$} & ${ }^{20} \mathrm{Ne}$ & $\cdots$ & $\cdots$ & 0.90 & 1.2 & $\cdots$ & $\cdots$ \\
\hline & ${ }^{21} \mathrm{Ne}$ & $\ldots$ & $\ldots$ & 1.9 & 0.59 & $\cdots$ & $\cdots$ \\
\hline & ${ }^{22} \mathrm{Na}$ & $\cdots$ & $\cdots$ & 1.8 & 0.57 & $\cdots$ & $\cdots$ \\
\hline \multirow[t]{2}{*}{${ }^{21} \mathrm{Na}(\mathrm{p}, \gamma){ }^{22} \mathrm{Mg}$} & ${ }^{21} \mathrm{Ne}$ & 0.075 & 0.31 & 0.71 & 1.4 & 3.2 & 9.2 \\
\hline & ${ }^{22} \mathrm{Na}$ & 0.81 & 0.81 & 0.90 & 1.2 & 2.1 & 6.2 \\
\hline${ }^{22} \mathrm{Na}(\mathrm{p}, \gamma)^{23} \mathrm{Mg}$ & ${ }^{22} \mathrm{Na}$ & $\cdots$ & $\cdots$ & 0.57 & 1.8 & $\ldots$ & $\cdots$ \\
\hline \multirow[t]{2}{*}{${ }^{23} \mathrm{Na}(\mathrm{p}, \gamma){ }^{24} \mathrm{Mg}$} & ${ }^{20} \mathrm{Ne}$ & $\cdots$ & 0.21 & 0.69 & 1.3 & 1.6 & 1.8 \\
\hline & ${ }^{21} \mathrm{Ne}$ & $\ldots$ & 0.20 & 0.69 & 1.3 & 1.6 & 1.7 \\
\hline
\end{tabular}


Table 7-Continued

\begin{tabular}{|c|c|c|c|c|c|c|c|}
\hline \multirow[t]{2}{*}{ Reaction } & \multirow[t]{2}{*}{ Isotope i } & \multicolumn{6}{|c|}{ Reaction rate multiplied by } \\
\hline & & 100 & 10 & 2 & 0.5 & 0.1 & 0.01 \\
\hline \multirow{20}{*}{$\left.{ }^{23} \mathrm{Na}(\mathrm{p}, \alpha)\right)^{20} \mathrm{Ne}$} & ${ }^{22} \mathrm{Na}$ & $\cdots$ & 0.20 & 0.67 & 1.3 & 1.6 & 1.7 \\
\hline & ${ }^{23} \mathrm{Na}$ & $\ldots$ & 0.33 & 0.78 & 1.2 & 1.4 & 1.4 \\
\hline & ${ }^{24} \mathrm{Mg}$ & $\cdots$ & 2.9 & 1.5 & 0.60 & 0.14 & 0.016 \\
\hline & ${ }^{25} \mathrm{Mg}$ & $\ldots$ & 2.1 & 1.4 & 0.65 & 0.21 & 0.068 \\
\hline & ${ }^{26} \mathrm{Al}$ & $\cdots$ & 2.0 & 1.4 & 0.68 & 0.23 & 0.10 \\
\hline & ${ }^{26} \mathrm{Mg}$ & $\ldots$ & 2.0 & 1.4 & 0.68 & 0.23 & 0.093 \\
\hline & ${ }^{27} \mathrm{Al}$ & $\ldots$ & 1.9 & 1.3 & 0.70 & 0.30 & 0.18 \\
\hline & ${ }^{28} \mathrm{Si}$ & $\ldots$ & 1.4 & 1.2 & 0.87 & 0.67 & 0.62 \\
\hline & ${ }^{29} \mathrm{Si}$ & $\ldots$ & 1.2 & 1.1 & 0.90 & 0.81 & 0.76 \\
\hline & ${ }^{30} \mathrm{Si}$ & $\ldots$ & 1.1 & 1.0 & 0.96 & 0.92 & 0.88 \\
\hline & ${ }^{20} \mathrm{Ne}$ & $\ldots$ & $\ldots$ & 1.3 & 0.69 & $\ldots$ & $\ldots$ \\
\hline & ${ }^{21} \mathrm{Ne}$ & $\ldots$ & $\ldots$ & 1.3 & 0.69 & $\ldots$ & $\ldots$ \\
\hline & ${ }^{22} \mathrm{Na}$ & $\ldots$ & $\ldots$ & 1.3 & 0.67 & $\ldots$ & $\ldots$ \\
\hline & ${ }^{23} \mathrm{Na}$ & $\ldots$ & $\ldots$ & 0.69 & 1.3 & $\ldots$ & $\cdots$ \\
\hline & ${ }^{24} \mathrm{Mg}$ & $\ldots$ & $\ldots$ & 0.67 & 1.4 & $\cdots$ & $\ldots$ \\
\hline & ${ }^{25} \mathrm{Mg}$ & $\ldots$ & $\ldots$ & 0.67 & 1.4 & $\ldots$ & $\ldots$ \\
\hline & ${ }^{26} \mathrm{Al}$ & $\ldots$ & $\ldots$ & 0.68 & 1.4 & $\ldots$ & $\ldots$ \\
\hline & ${ }^{26} \mathrm{Mg}$ & $\ldots$ & $\ldots$ & 0.68 & 1.4 & $\ldots$ & $\ldots$ \\
\hline & ${ }^{27} \mathrm{Al}$ & $\ldots$ & $\ldots$ & 0.71 & 1.3 & $\ldots$ & $\ldots$ \\
\hline & ${ }^{28} \mathrm{Si}$ & $\cdots$ & $\ldots$ & 0.87 & 1.2 & $\ldots$ & $\cdots$ \\
\hline \multirow[t]{24}{*}{${ }^{23} \mathrm{Mg}(\mathrm{p}, \gamma){ }^{24} \mathrm{Al}$} & ${ }^{1} \mathrm{H}$ & 0.93 & 0.93 & 0.93 & 1.0 & 1.1 & 1.3 \\
\hline & ${ }^{17} \mathrm{O}$ & 1.0 & 1.0 & 1.0 & 0.96 & 0.85 & 0.73 \\
\hline & ${ }^{18} \mathrm{~F}$ & 1.1 & 1.1 & 1.1 & 1.0 & 0.90 & 0.75 \\
\hline & ${ }^{18} \mathrm{O}$ & 1.1 & 1.0 & 1.0 & 1.0 & 0.86 & 0.73 \\
\hline & ${ }^{20} \mathrm{Ne}$ & 0.095 & 0.38 & 0.79 & 1.2 & 2.0 & 2.9 \\
\hline & ${ }^{21} \mathrm{Ne}$ & 0.095 & 0.39 & 0.78 & 1.3 & 1.9 & 2.9 \\
\hline & ${ }^{22} \mathrm{Na}$ & 0.095 & 0.38 & 0.76 & 1.2 & 2.0 & 2.9 \\
\hline & ${ }^{23} \mathrm{Na}$ & 0.15 & 0.47 & 0.83 & 1.2 & 1.6 & 2.2 \\
\hline & ${ }^{24} \mathrm{Mg}$ & 0.15 & 0.49 & 0.84 & 1.2 & 1.6 & 2.1 \\
\hline & ${ }^{25} \mathrm{Mg}$ & 0.41 & 0.59 & 0.86 & 1.2 & 1.6 & 2.1 \\
\hline & ${ }^{26} \mathrm{Al}$ & 0.60 & 0.68 & 0.88 & 1.2 & 1.5 & 2.0 \\
\hline & ${ }^{26} \mathrm{Mg}$ & 0.54 & 0.64 & 0.89 & 1.2 & 1.6 & 2.1 \\
\hline & ${ }^{27} \mathrm{Al}$ & 0.94 & 0.86 & 0.92 & 1.1 & 1.4 & 1.9 \\
\hline & ${ }^{28} \mathrm{Si}$ & 1.5 & 1.3 & 1.1 & 0.98 & 1.1 & 1.3 \\
\hline & ${ }^{29} \mathrm{Si}$ & 1.6 & 1.4 & 1.1 & 0.90 & 0.86 & 0.90 \\
\hline & ${ }^{30} \mathrm{Si}$ & 1.4 & 1.3 & 1.1 & 0.88 & 0.67 & 0.58 \\
\hline & ${ }^{31} \mathrm{P}$ & 1.3 & 1.2 & 1.1 & 0.89 & 0.67 & 0.44 \\
\hline & ${ }^{32} \mathrm{~S}$ & 1.1 & 1.1 & 1.0 & 0.95 & 0.76 & 0.47 \\
\hline & ${ }^{33} \mathrm{~S}$ & 1.1 & 1.1 & 1.0 & 0.94 & 0.75 & 0.43 \\
\hline & ${ }^{34} \mathrm{~S}$ & 1.1 & 1.1 & 1.0 & 0.96 & 0.78 & 0.48 \\
\hline & ${ }^{35} \mathrm{Cl}$ & 1.0 & 1.0 & 1.0 & 1.0 & 0.83 & 0.60 \\
\hline & ${ }^{36} \mathrm{Ar}$ & 1.0 & 1.0 & 1.0 & 0.98 & 0.84 & 0.60 \\
\hline & ${ }^{37} \mathrm{Ar}$ & 1.0 & 1.0 & 1.0 & 0.97 & 0.91 & 0.76 \\
\hline & ${ }^{37} \mathrm{Cl}$ & 1.0 & 1.0 & 1.0 & 0.99 & 0.90 & 0.74 \\
\hline \multirow[t]{3}{*}{${ }^{24} \mathrm{Al}(\mathrm{p}, \gamma){ }^{25} \mathrm{Si}$} & ${ }^{28} \mathrm{Si}$ & 0.95 & 0.95 & 0.98 & 1.1 & 1.2 & 1.4 \\
\hline & ${ }^{29} \mathrm{Si}$ & 0.95 & 0.95 & 1.0 & 1.0 & 1.2 & 1.4 \\
\hline & ${ }^{30} \mathrm{Si}$ & 1.0 & 1.0 & 1.0 & 1.0 & 1.1 & 1.3 \\
\hline
\end{tabular}


Table 7-Continued

\begin{tabular}{|c|c|c|c|c|c|c|c|}
\hline \multirow[t]{2}{*}{ Reaction } & \multirow[t]{2}{*}{ Isotope i } & \multicolumn{6}{|c|}{ Reaction rate multiplied by } \\
\hline & & 100 & 10 & 2 & 0.5 & 0.1 & 0.01 \\
\hline \multirow{6}{*}{${ }^{25} \mathrm{Mg}(\mathrm{p}, \gamma)^{26} \mathrm{Al}^{g}$} & ${ }^{33} \mathrm{~S}$ & 1.0 & 1.0 & 1.0 & 0.97 & 0.92 & 0.80 \\
\hline & ${ }^{34} \mathrm{~S}$ & 1.0 & 1.0 & 1.0 & 0.99 & 0.93 & 0.79 \\
\hline & ${ }^{36} \mathrm{Ar}$ & 1.0 & 1.0 & 1.0 & 1.0 & 0.95 & 0.82 \\
\hline & ${ }^{25} \mathrm{Mg}$ & $\ldots$ & $\ldots$ & 0.68 & 1.4 & $\ldots$ & $\ldots$ \\
\hline & ${ }^{26} \mathrm{Al}$ & $\cdots$ & $\cdots$ & 1.2 & 0.76 & $\cdots$ & $\cdots$ \\
\hline & ${ }^{26} \mathrm{Mg}$ & $\ldots$ & $\ldots$ & 0.64 & 1.5 & $\ldots$ & $\ldots$ \\
\hline${ }^{25} \mathrm{Mg}(\mathrm{p}, \gamma){ }^{26} \mathrm{Al}^{m}$ & ${ }^{26} \mathrm{Mg}$ & $\ldots$ & $\ldots$ & 1.8 & 0.54 & $\ldots$ & $\ldots$ \\
\hline \multirow[t]{19}{*}{${ }^{25} \mathrm{Al}(\mathrm{p}, \gamma){ }^{26} \mathrm{Si}$} & ${ }^{17} \mathrm{O}$ & 1.0 & 1.0 & 1.0 & 1.0 & 0.96 & 0.81 \\
\hline & ${ }^{18} \mathrm{~F}$ & 1.1 & 1.1 & 1.0 & 1.0 & 1.0 & 0.84 \\
\hline & ${ }^{18} \mathrm{O}$ & 1.0 & 1.0 & 1.0 & 1.0 & 1.0 & 0.81 \\
\hline & ${ }^{25} \mathrm{Mg}$ & 0.67 & 0.87 & 0.97 & 1.0 & 1.1 & 1.1 \\
\hline & ${ }^{26} \mathrm{Mg}$ & 1.0 & 0.89 & 0.96 & 1.0 & 1.1 & 1.3 \\
\hline & ${ }^{26} \mathrm{Al}$ & 0.52 & 0.80 & 0.96 & 1.0 & 1.2 & 1.3 \\
\hline & ${ }^{27} \mathrm{Al}$ & 0.67 & 0.78 & 0.93 & 1.1 & 1.3 & 1.6 \\
\hline & ${ }^{28} \mathrm{Si}$ & 1.0 & 0.96 & 0.98 & 1.1 & 1.3 & 2.0 \\
\hline & ${ }^{29} \mathrm{Si}$ & 1.0 & 1.0 & 1.0 & 1.0 & 1.1 & 1.7 \\
\hline & ${ }^{30} \mathrm{Si}$ & 1.1 & 1.0 & 1.0 & 0.96 & 0.96 & 1.3 \\
\hline & ${ }^{32} \mathrm{~S}$ & 1.0 & 1.0 & 1.0 & 1.0 & 0.95 & 0.81 \\
\hline & ${ }^{33} \mathrm{~S}$ & 1.0 & 1.0 & 1.0 & 1.0 & 0.92 & 0.71 \\
\hline & ${ }^{34} \mathrm{~S}$ & 1.0 & 1.0 & 1.0 & 1.0 & 0.95 & 0.71 \\
\hline & ${ }^{35} \mathrm{Cl}$ & 1.0 & 1.0 & 1.0 & 1.0 & 0.97 & 0.73 \\
\hline & ${ }^{36} \mathrm{Ar}$ & 1.0 & 1.0 & 1.0 & 1.0 & 0.95 & 0.73 \\
\hline & ${ }^{37} \mathrm{Ar}$ & 1.0 & 1.0 & 1.0 & 1.0 & 0.94 & 0.76 \\
\hline & ${ }^{37} \mathrm{Cl}$ & 1.0 & 1.0 & 1.0 & 1.0 & 0.95 & 0.76 \\
\hline & ${ }^{38} \mathrm{Ar}$ & 1.0 & 1.0 & 1.0 & 1.0 & 0.95 & 0.81 \\
\hline & ${ }^{39} \mathrm{~K}$ & 1.1 & 1.0 & 1.0 & 1.0 & 0.95 & 0.82 \\
\hline${ }^{26} \mathrm{Mg}(\mathrm{p}, \gamma){ }^{27} \mathrm{Al}$ & ${ }^{26} \mathrm{Mg}$ & $\ldots$ & $\ldots$ & 0.68 & 1.4 & $\ldots$ & $\ldots$ \\
\hline${ }^{26} \mathrm{Al}^{g}(\mathrm{p}, \gamma){ }^{27} \mathrm{Si}$ & ${ }^{26} \mathrm{Al}$ & $\ldots$ & 0.072 & 0.48 & 1.9 & $\cdots$ & $\cdots$ \\
\hline${ }^{26} \mathrm{Al}^{m}(\mathrm{p}, \gamma){ }^{27} \mathrm{Si}$ & ${ }^{26} \mathrm{Mg}$ & 0.071 & 0.36 & 0.79 & 1.2 & 1.6 & 1.9 \\
\hline \multirow[t]{3}{*}{${ }^{26} \mathrm{Si}(\mathrm{p}, \gamma){ }^{27} \mathrm{P}$} & ${ }^{28} \mathrm{Si}$ & 0.98 & 1.0 & 1.0 & 1.0 & 1.1 & 1.3 \\
\hline & ${ }^{29} \mathrm{Si}$ & 1.0 & 1.0 & 1.0 & 1.0 & 1.1 & 1.3 \\
\hline & ${ }^{30} \mathrm{Si}$ & 1.0 & 1.0 & 1.0 & 1.0 & 1.0 & 1.3 \\
\hline \multirow[t]{3}{*}{${ }^{27} \mathrm{Si}(\mathrm{p}, \gamma){ }^{28} \mathrm{P}$} & ${ }^{27} \mathrm{Al}$ & $\cdots$ & 0.82 & 0.96 & 1.0 & 1.0 & $\ldots$ \\
\hline & ${ }^{28} \mathrm{Si}$ & $\ldots$ & 0.96 & 0.98 & 1.1 & 1.3 & $\ldots$ \\
\hline & ${ }^{29} \mathrm{Si}$ & $\ldots$ & 1.0 & 1.0 & 1.0 & 1.2 & $\ldots$ \\
\hline \multirow[t]{3}{*}{${ }^{28} \mathrm{Si}(\mathrm{p}, \gamma){ }^{29} \mathrm{P}$} & ${ }^{28} \mathrm{Si}$ & $\ldots$ & $\ldots$ & 0.78 & 1.3 & $\cdots$ & $\ldots$ \\
\hline & ${ }^{29} \mathrm{Si}$ & $\ldots$ & $\cdots$ & 1.4 & 0.71 & $\cdots$ & $\cdots$ \\
\hline & ${ }^{30} \mathrm{Si}$ & $\cdots$ & $\ldots$ & 1.2 & 0.79 & $\ldots$ & $\ldots$ \\
\hline \multirow[t]{2}{*}{${ }^{29} \mathrm{Si}(\mathrm{p}, \gamma){ }^{30} \mathrm{P}$} & ${ }^{29} \mathrm{Si}$ & $\ldots$ & 0.095 & 0.52 & 2.0 & 7.1 & $\ldots$ \\
\hline & ${ }^{30} \mathrm{Si}$ & $\cdots$ & 1.0 & 1.0 & 0.96 & 0.75 & $\ldots$ \\
\hline \multirow[t]{7}{*}{${ }^{29} \mathrm{P}(\mathrm{p}, \gamma){ }^{30} \mathrm{~S}$} & ${ }^{29} \mathrm{Si}$ & 0.48 & 0.76 & 0.95 & 1.1 & 1.2 & 1.4 \\
\hline & ${ }^{30} \mathrm{Si}$ & 0.54 & 0.67 & 0.88 & 1.1 & 1.5 & 1.8 \\
\hline & ${ }^{31} \mathrm{P}$ & 0.78 & 0.81 & 0.89 & 1.1 & 1.4 & 1.6 \\
\hline & ${ }^{33} \mathrm{~S}$ & 1.1 & 1.0 & 1.0 & 0.95 & 0.86 & 0.77 \\
\hline & ${ }^{34} \mathrm{~S}$ & 1.1 & 1.1 & 1.0 & 0.96 & 0.84 & 0.71 \\
\hline & ${ }^{35} \mathrm{Cl}$ & 1.1 & 1.1 & 1.0 & 0.97 & 0.80 & 0.63 \\
\hline & ${ }^{36} \mathrm{Ar}$ & 1.1 & 1.1 & 1.0 & 0.97 & 0.79 & 0.60 \\
\hline
\end{tabular}


Table 7-Continued

\begin{tabular}{|c|c|c|c|c|c|c|c|}
\hline \multirow[t]{2}{*}{ Reaction } & \multirow[t]{2}{*}{ Isotope $\mathrm{i}$} & \multicolumn{6}{|c|}{ Reaction rate multiplied by } \\
\hline & & 100 & 10 & 2 & 0.5 & 0.1 & 0.01 \\
\hline \multirow{18}{*}{${ }^{30} \mathrm{P}(\mathrm{p}, \gamma)^{31} \mathrm{~S}$} & ${ }^{37} \mathrm{Ar}$ & 1.1 & 1.1 & 1.0 & 0.94 & 0.76 & 0.55 \\
\hline & ${ }^{37} \mathrm{Cl}$ & 1.1 & 1.0 & 1.0 & 0.95 & 0.76 & 0.56 \\
\hline & ${ }^{38} \mathrm{Ar}$ & 1.1 & 1.0 & 1.0 & 0.95 & 0.71 & 0.52 \\
\hline & ${ }^{39} \mathrm{~K}$ & 1.1 & 1.1 & 1.0 & 0.93 & 0.70 & 0.52 \\
\hline & ${ }^{40} \mathrm{Ca}$ & 1.2 & 1.2 & 1.1 & 0.92 & 0.70 & 0.52 \\
\hline & ${ }^{29} \mathrm{Si}$ & 1.0 & 1.0 & 1.0 & 1.0 & 0.95 & 0.81 \\
\hline & ${ }^{30} \mathrm{Si}$ & 0.012 & 0.14 & 0.58 & 1.6 & 3.9 & 9.6 \\
\hline & ${ }^{31} \mathrm{P}$ & 1.3 & 1.2 & 1.1 & 0.85 & 0.56 & 0.24 \\
\hline & ${ }^{32} \mathrm{~S}$ & 1.0 & 1.1 & 1.0 & 0.95 & 0.81 & 0.40 \\
\hline & ${ }^{33} \mathrm{~S}$ & 1.0 & 1.0 & 1.0 & 0.95 & 0.82 & 0.42 \\
\hline & ${ }^{34} \mathrm{~S}$ & 1.0 & 1.0 & 1.0 & 0.98 & 0.85 & 0.45 \\
\hline & ${ }^{35} \mathrm{Cl}$ & 1.0 & 1.0 & 1.0 & 1.0 & 0.90 & 0.50 \\
\hline & ${ }^{36} \mathrm{Ar}$ & 1.0 & 1.0 & 1.0 & 0.98 & 0.90 & 0.50 \\
\hline & ${ }^{37} \mathrm{Ar}$ & 1.0 & 1.0 & 1.0 & 0.97 & 0.91 & 0.55 \\
\hline & ${ }^{37} \mathrm{Cl}$ & 1.0 & 1.0 & 1.0 & 0.99 & 0.93 & 0.55 \\
\hline & ${ }^{38} \mathrm{Ar}$ & 1.0 & 1.0 & 1.0 & 1.0 & 0.95 & 0.57 \\
\hline & ${ }^{39} \mathrm{~K}$ & 1.0 & 1.0 & 1.0 & 0.99 & 0.93 & 0.55 \\
\hline & ${ }^{40} \mathrm{Ca}$ & 1.0 & 1.0 & 1.0 & 1.0 & 0.92 & 0.52 \\
\hline \multirow[t]{13}{*}{${ }^{31} \mathrm{P}(\mathrm{p}, \alpha){ }^{28} \mathrm{Si}$} & ${ }^{28} \mathrm{Si}$ & $\ldots$ & 2.4 & 1.2 & 0.91 & $\ldots$ & $\ldots$ \\
\hline & ${ }^{29} \mathrm{Si}$ & $\ldots$ & 2.7 & 1.3 & 0.86 & $\ldots$ & $\ldots$ \\
\hline & ${ }^{30} \mathrm{Si}$ & $\ldots$ & 2.5 & 1.3 & 0.83 & $\ldots$ & $\ldots$ \\
\hline & ${ }^{32} \mathrm{~S}$ & $\ldots$ & 0.67 & 0.95 & 1.0 & $\cdots$ & $\cdots$ \\
\hline & ${ }^{33} \mathrm{~S}$ & $\ldots$ & 0.55 & 0.91 & 1.0 & $\ldots$ & $\ldots$ \\
\hline & ${ }^{34} \mathrm{~S}$ & $\cdots$ & 0.53 & 0.90 & 1.1 & $\cdots$ & $\cdots$ \\
\hline & ${ }^{35} \mathrm{Cl}$ & $\ldots$ & 0.53 & 0.90 & 1.1 & $\ldots$ & $\ldots$ \\
\hline & ${ }^{36} \mathrm{Ar}$ & $\ldots$ & 0.53 & 0.90 & 1.1 & $\ldots$ & $\ldots$ \\
\hline & ${ }^{37} \mathrm{Ar}$ & $\ldots$ & 0.52 & 0.88 & 1.1 & $\ldots$ & $\ldots$ \\
\hline & ${ }^{37} \mathrm{Cl}$ & $\ldots$ & 0.52 & 0.89 & 1.1 & $\ldots$ & $\ldots$ \\
\hline & ${ }^{38} \mathrm{Ar}$ & $\ldots$ & 0.52 & 0.90 & 1.0 & $\ldots$ & $\ldots$ \\
\hline & ${ }^{39} \mathrm{~K}$ & $\ldots$ & 0.55 & 0.89 & 1.1 & $\cdots$ & $\ldots$ \\
\hline & ${ }^{40} \mathrm{Ca}$ & $\ldots$ & 0.56 & 0.90 & 1.1 & $\ldots$ & $\ldots$ \\
\hline \multirow[t]{6}{*}{${ }^{31} \mathrm{~S}(\mathrm{p}, \gamma){ }^{32} \mathrm{Cl}$} & ${ }^{36} \mathrm{Ar}$ & $\ldots$ & 1.2 & 1.0 & 0.98 & 0.95 & $\ldots$ \\
\hline & ${ }^{37} \mathrm{Ar}$ & $\ldots$ & 1.4 & 1.1 & 0.94 & 0.91 & $\ldots$ \\
\hline & ${ }^{37} \mathrm{Cl}$ & $\ldots$ & 1.3 & 1.1 & 0.95 & 0.91 & $\ldots$ \\
\hline & ${ }^{38} \mathrm{Ar}$ & $\ldots$ & 1.6 & 1.1 & 0.90 & 0.86 & $\cdots$ \\
\hline & ${ }^{39} \mathrm{~K}$ & $\ldots$ & 1.8 & 1.2 & 0.90 & 0.84 & $\ldots$ \\
\hline & ${ }^{40} \mathrm{Ca}$ & $\cdots$ & 1.9 & 1.2 & 0.92 & 0.84 & $\cdots$ \\
\hline \multirow[t]{9}{*}{${ }^{32} \mathrm{~S}(\mathrm{p}, \gamma){ }^{33} \mathrm{Cl}$} & ${ }^{33} \mathrm{~S}$ & $\ldots$ & $\ldots$ & 1.5 & 0.62 & $\cdots$ & $\ldots$ \\
\hline & ${ }^{34} \mathrm{~S}$ & $\ldots$ & $\ldots$ & 1.5 & 0.64 & $\cdots$ & $\ldots$ \\
\hline & ${ }^{35} \mathrm{Cl}$ & $\ldots$ & $\ldots$ & 1.3 & 0.73 & $\cdots$ & $\cdots$ \\
\hline & ${ }^{36} \mathrm{Ar}$ & $\ldots$ & $\ldots$ & 1.3 & 0.74 & $\ldots$ & $\cdots$ \\
\hline & ${ }^{37} \mathrm{Ar}$ & $\ldots$ & $\ldots$ & 1.2 & 0.79 & $\ldots$ & $\ldots$ \\
\hline & ${ }^{37} \mathrm{Cl}$ & $\ldots$ & $\ldots$ & 1.2 & 0.78 & $\ldots$ & $\ldots$ \\
\hline & ${ }^{38} \mathrm{Ar}$ & & $\ldots$ & 1.1 & 0.81 & $\ldots$ & $\ldots$ \\
\hline & ${ }^{39} \mathrm{~K}$ & & $\ldots$ & 1.1 & 0.84 & $\ldots$ & $\ldots$ \\
\hline & ${ }^{40} \mathrm{Ca}$ & $\cdots$ & $\cdots$ & 1.1 & 0.84 & $\cdots$ & $\cdots$ \\
\hline${ }^{33} \mathrm{~S}(\mathrm{p}, \gamma){ }^{34} \mathrm{Cl}$ & ${ }^{33} \mathrm{~S}$ & 0.00091 & 0.051 & 0.48 & 1.7 & 4.2 & 6.5 \\
\hline
\end{tabular}


Table 7-Continued

\begin{tabular}{|c|c|c|c|c|c|c|c|}
\hline \multirow[t]{2}{*}{ Reaction } & \multirow[t]{2}{*}{ Isotope i } & \multicolumn{6}{|c|}{ Reaction rate multiplied by } \\
\hline & & 100 & 10 & 2 & 0.5 & 0.1 & 0.01 \\
\hline \multirow{14}{*}{${ }^{34} \mathrm{~S}(\mathrm{p}, \gamma){ }^{35} \mathrm{Cl}$} & ${ }^{34} \mathrm{~S}$ & 1.0 & 1.2 & 1.1 & 0.86 & 0.49 & 0.22 \\
\hline & ${ }^{35} \mathrm{Cl}$ & 1.0 & 1.1 & 1.1 & 0.93 & 0.73 & 0.53 \\
\hline & ${ }^{36} \mathrm{Ar}$ & 1.0 & 1.1 & 1.1 & 0.95 & 0.77 & 0.63 \\
\hline & ${ }^{37} \mathrm{Ar}$ & 1.0 & 1.0 & 1.0 & 0.97 & 0.85 & 0.76 \\
\hline & ${ }^{37} \mathrm{Cl}$ & 1.0 & 1.0 & 1.0 & 0.98 & 0.87 & 0.76 \\
\hline & ${ }^{38} \mathrm{Ar}$ & 1.0 & 1.0 & 1.0 & 1.0 & 0.90 & 0.86 \\
\hline & ${ }^{39} \mathrm{~K}$ & 1.0 & 1.0 & 1.0 & 0.99 & 0.96 & 0.88 \\
\hline & ${ }^{34} \mathrm{~S}$ & 0.0093 & 0.11 & 0.55 & 1.6 & 3.2 & 4.4 \\
\hline & ${ }^{35} \mathrm{Cl}$ & 1.0 & 1.2 & 1.1 & 0.90 & 0.63 & 0.50 \\
\hline & ${ }^{36} \mathrm{Ar}$ & 1.0 & 1.1 & 1.1 & 0.92 & 0.73 & 0.58 \\
\hline & ${ }^{37} \mathrm{Ar}$ & 1.0 & 1.1 & 1.0 & 0.94 & 0.82 & 0.73 \\
\hline & ${ }^{37} \mathrm{Cl}$ & 1.0 & 1.1 & 1.0 & 0.95 & 0.83 & 0.73 \\
\hline & ${ }^{38} \mathrm{Ar}$ & 1.0 & 1.0 & 1.0 & 0.95 & 0.90 & 0.81 \\
\hline & ${ }^{39} \mathrm{~K}$ & 1.0 & 1.0 & 1.0 & 0.99 & 0.95 & 0.88 \\
\hline \multirow[t]{7}{*}{${ }^{33} \mathrm{Cl}(\mathrm{p}, \gamma){ }^{34} \mathrm{Ar}$} & ${ }^{33} \mathrm{~S}$ & 0.095 & 0.40 & 0.80 & 1.2 & 1.5 & 1.7 \\
\hline & ${ }^{34} \mathrm{~S}$ & 0.62 & 0.67 & 0.87 & 1.2 & 1.4 & 1.6 \\
\hline & ${ }^{37} \mathrm{Ar}$ & 1.0 & 1.1 & 1.0 & 0.94 & 0.88 & 0.85 \\
\hline & ${ }^{37} \mathrm{Cl}$ & 1.0 & 1.1 & 1.0 & 0.96 & 0.89 & 0.87 \\
\hline & ${ }^{38} \mathrm{Ar}$ & 1.0 & 1.1 & 1.0 & 0.95 & 0.81 & 0.71 \\
\hline & ${ }^{39} \mathrm{~K}$ & 1.0 & 1.1 & 1.1 & 0.92 & 0.73 & 0.63 \\
\hline & ${ }^{40} \mathrm{Ca}$ & 1.0 & 1.1 & 1.1 & 0.92 & 0.70 & 0.58 \\
\hline${ }^{34} \mathrm{Cl}(\mathrm{p}, \gamma){ }^{35} \mathrm{Ar}$ & ${ }^{34} \mathrm{~S}$ & 0.20 & 0.56 & 0.87 & 1.1 & 1.3 & 1.4 \\
\hline \multirow{6}{*}{${ }^{35} \mathrm{Cl}(\mathrm{p}, \gamma){ }^{36} \mathrm{Ar}$} & ${ }^{35} \mathrm{Cl}$ & $\ldots$ & $\ldots$ & 0.67 & 1.4 & $\cdots$ & $\cdots$ \\
\hline & ${ }^{36} \mathrm{Ar}$ & $\cdots$ & $\cdots$ & 1.3 & 0.73 & $\cdots$ & $\cdots$ \\
\hline & ${ }^{37} \mathrm{Ar}$ & $\ldots$ & $\ldots$ & 1.2 & 0.76 & $\ldots$ & $\ldots$ \\
\hline & ${ }^{37} \mathrm{Cl}$ & $\ldots$ & $\ldots$ & 1.2 & 0.77 & $\ldots$ & $\ldots$ \\
\hline & ${ }^{38} \mathrm{Ar}$ & $\cdots$ & $\cdots$ & 1.1 & 0.81 & $\cdots$ & $\cdots$ \\
\hline & ${ }^{39} \mathrm{~K}$ & $\ldots$ & $\ldots$ & 1.1 & 0.85 & $\ldots$ & $\cdots$ \\
\hline \multirow[t]{7}{*}{${ }^{35} \mathrm{Cl}(\mathrm{p}, \alpha){ }^{32} \mathrm{~S}$} & ${ }^{35} \mathrm{Cl}$ & $\ldots$ & 0.83 & 1.0 & 1.0 & 1.0 & 1.0 \\
\hline & ${ }^{36} \mathrm{Ar}$ & $\cdots$ & 0.82 & 0.98 & 1.0 & 1.0 & 1.0 \\
\hline & ${ }^{37} \mathrm{Ar}$ & $\cdots$ & 0.79 & 0.97 & 1.0 & 1.0 & 1.0 \\
\hline & ${ }^{37} \mathrm{Cl}$ & $\ldots$ & 0.78 & 0.96 & 1.0 & 1.0 & 1.0 \\
\hline & ${ }^{38} \mathrm{Ar}$ & $\cdots$ & 0.76 & 0.95 & 1.0 & 1.0 & 1.0 \\
\hline & ${ }^{39} \mathrm{~K}$ & $\ldots$ & 0.71 & 0.96 & 1.0 & 1.0 & 1.0 \\
\hline & ${ }^{40} \mathrm{Ca}$ & $\ldots$ & 0.72 & 0.96 & 1.0 & 1.1 & 1.1 \\
\hline \multirow[t]{2}{*}{${ }^{35} \operatorname{Ar}(\mathrm{p}, \gamma){ }^{36} \mathrm{~K}$} & ${ }^{39} \mathrm{~K}$ & $\ldots$ & 1.3 & 1.0 & 0.96 & 0.95 & $\cdots$ \\
\hline & ${ }^{40} \mathrm{Ca}$ & $\cdots$ & 1.5 & 1.1 & 0.96 & 0.92 & $\cdots$ \\
\hline \multirow[t]{5}{*}{${ }^{37} \operatorname{Ar}(\mathrm{p}, \gamma){ }^{38} \mathrm{~K}$} & ${ }^{37} \mathrm{Ar}$ & 0.026 & 0.22 & 0.70 & 1.3 & 1.7 & 1.9 \\
\hline & ${ }^{37} \mathrm{Cl}$ & 0.026 & 0.23 & 0.71 & 1.2 & 1.7 & 2.0 \\
\hline & ${ }^{38} \mathrm{Ar}$ & 2.0 & 1.8 & 1.3 & 0.71 & 0.30 & 0.14 \\
\hline & ${ }^{39} \mathrm{~K}$ & 1.5 & 1.5 & 1.2 & 0.79 & 0.44 & 0.27 \\
\hline & ${ }^{40} \mathrm{Ca}$ & 1.3 & 1.2 & 1.1 & 0.88 & 0.58 & 0.40 \\
\hline \multirow[t]{5}{*}{${ }^{37} \mathrm{~K}(\mathrm{p}, \gamma){ }^{38} \mathrm{Ca}$} & ${ }^{37} \mathrm{Ar}$ & 0.42 & 0.79 & 0.94 & 1.0 & 1.0 & 1.0 \\
\hline & ${ }^{37} \mathrm{Cl}$ & 0.41 & 0.79 & 0.96 & 1.0 & 1.0 & 1.0 \\
\hline & ${ }^{38} \mathrm{Ar}$ & 1.4 & 1.1 & 1.0 & 1.0 & 1.0 & 1.0 \\
\hline & ${ }^{39} \mathrm{~K}$ & 1.6 & 1.3 & 1.1 & 0.96 & 0.92 & 0.90 \\
\hline & ${ }^{40} \mathrm{Ca}$ & 1.7 & 1.4 & 1.1 & 0.94 & 0.86 & 0.84 \\
\hline
\end{tabular}


Table 7-Continued

\begin{tabular}{clcccccc}
\hline \hline \multirow{2}{*}{ Reaction } & Isotope i & \multicolumn{5}{c}{ Reaction rate multiplied by } \\
\cline { 3 - 7 } & & 100 & 10 & 2 & 0.5 & 0.1 & 0.01 \\
\hline${ }^{38} \mathrm{~K}(\mathrm{p}, \gamma){ }^{39} \mathrm{Ca}$ & ${ }^{38} \mathrm{Ar}$ & 0.057 & 0.35 & 0.81 & 1.1 & 1.4 & 1.4 \\
& ${ }^{39} \mathrm{~K}$ & 3.4 & 2.6 & 1.5 & 0.63 & 0.19 & 0.059 \\
& ${ }^{40} \mathrm{Ca}$ & 2.4 & 2.0 & 1.4 & 0.66 & 0.20 & 0.042 \\
${ }^{39} \mathrm{~K}(\mathrm{p}, \gamma)^{40} \mathrm{Ca}$ & ${ }^{39} \mathrm{~K}$ & 0.030 & 0.26 & 0.74 & 1.2 & 1.5 & 1.6 \\
& ${ }^{40} \mathrm{Ca}$ & 2.4 & 2.2 & 1.4 & 0.66 & 0.19 & 0.026 \\
\hline
\end{tabular}

NOTE.- See $\S 4$ for an explanation of the quantities listed here. 
Table 8. FINAL ABUNDANCE CHANGES $\mathrm{X}_{i} / \mathrm{X}_{i, \text { rec }}$ RESULTING FROM REACTION RATE VARIATIONS FOR ONe NOVA MODEL JCH1 $\left(\mathrm{T}_{P E A K}=0.231 \mathrm{GK}\right)$

\begin{tabular}{|c|c|c|c|c|c|c|c|}
\hline \multirow[t]{2}{*}{ Reaction } & \multirow[t]{2}{*}{ Isotope i } & \multicolumn{6}{|c|}{ Reaction rate multiplied by } \\
\hline & & 100 & 10 & 2 & 0.5 & 0.1 & 0.01 \\
\hline${ }^{3} \mathrm{He}(\alpha, \gamma)^{7} \mathrm{Be}$ & ${ }^{7} \mathrm{Be}$ & $\cdots$ & $\cdots$ & 0.28 & 1.6 & $\cdots$ & $\ldots$ \\
\hline${ }^{7} \mathrm{Be}(\mathrm{p}, \gamma)^{8} \mathrm{~B}$ & ${ }^{7} \mathrm{Be}$ & $\ldots$ & $\ldots$ & 0.0019 & 40 & $\ldots$ & $\ldots$ \\
\hline${ }^{8} \mathrm{~B}(\mathrm{p}, \gamma){ }^{9} \mathrm{C}$ & ${ }^{7} \mathrm{Be}$ & $\ldots$ & 0.38 & 0.84 & 1.1 & 1.2 & $\ldots$ \\
\hline \multirow{3}{*}{${ }^{13} \mathrm{~N}(\mathrm{p}, \gamma)^{14} \mathrm{O}$} & ${ }^{12} \mathrm{C}$ & $\ldots$ & $\ldots$ & 1.1 & 0.86 & $\ldots$ & $\ldots$ \\
\hline & ${ }^{13} \mathrm{C}$ & $\ldots$ & $\ldots$ & 0.78 & 1.1 & $\cdots$ & $\ldots$ \\
\hline & ${ }^{18} \mathrm{O}$ & $\ldots$ & $\cdots$ & 1.1 & 0.88 & $\cdots$ & $\ldots$ \\
\hline \multirow[t]{4}{*}{${ }^{14} \mathrm{~N}(\mathrm{p}, \gamma){ }^{15} \mathrm{O}$} & ${ }^{12} \mathrm{C}$ & $\ldots$ & $\ldots$ & 1.3 & 0.71 & $\ldots$ & $\ldots$ \\
\hline & ${ }^{13} \mathrm{C}$ & $\ldots$ & $\cdots$ & 1.2 & 0.81 & $\cdots$ & $\cdots$ \\
\hline & ${ }^{14} \mathrm{~N}$ & $\ldots$ & $\ldots$ & 0.80 & 1.3 & $\cdots$ & $\ldots$ \\
\hline & ${ }^{15} \mathrm{~N}$ & $\cdots$ & $\cdots$ & 1.3 & 0.77 & $\cdots$ & $\cdots$ \\
\hline${ }^{15} \mathrm{~N}(\mathrm{p}, \alpha){ }^{12} \mathrm{C}$ & ${ }^{15} \mathrm{~N}$ & $\ldots$ & $\ldots$ & 0.66 & 1.7 & $\cdots$ & $\cdots$ \\
\hline \multirow[t]{6}{*}{${ }^{16} \mathrm{O}(\mathrm{p}, \gamma)^{17} \mathrm{~F}$} & ${ }^{13} \mathrm{C}$ & $\ldots$ & $\cdots$ & 1.0 & 0.89 & $\cdots$ & $\cdots$ \\
\hline & ${ }^{16} \mathrm{O}$ & $\ldots$ & $\ldots$ & 0.07 & 7.9 & $\ldots$ & $\ldots$ \\
\hline & ${ }^{17} \mathrm{O}$ & $\ldots$ & $\ldots$ & 0.71 & 1.5 & $\ldots$ & $\ldots$ \\
\hline & ${ }^{18} \mathrm{O}$ & $\ldots$ & $\ldots$ & 0.71 & 1.4 & $\ldots$ & $\ldots$ \\
\hline & ${ }^{18} \mathrm{~F}$ & $\ldots$ & $\ldots$ & 0.71 & 1.4 & $\cdots$ & $\ldots$ \\
\hline & ${ }^{19} \mathrm{~F}$ & $\ldots$ & $\ldots$ & 0.71 & 1.5 & $\ldots$ & $\ldots$ \\
\hline \multirow[t]{4}{*}{${ }^{17} \mathrm{O}(\mathrm{p}, \gamma){ }^{18} \mathrm{~F}$} & ${ }^{17} \mathrm{O}$ & $\ldots$ & 0.16 & 0.71 & 1.2 & 1.5 & $\cdots$ \\
\hline & ${ }^{18} \mathrm{O}$ & $\ldots$ & 1.6 & 1.4 & 0.59 & 0.14 & $\ldots$ \\
\hline & ${ }^{18} \mathrm{~F}$ & $\ldots$ & 1.6 & 1.4 & 0.62 & 0.14 & $\ldots$ \\
\hline & ${ }^{19} \mathrm{~F}$ & $\ldots$ & 1.5 & 1.5 & 0.60 & 0.15 & $\ldots$ \\
\hline \multirow[t]{4}{*}{${ }^{17} \mathrm{O}(\mathrm{p}, \alpha){ }^{14} \mathrm{~N}$} & ${ }^{17} \mathrm{O}$ & $\ldots$ & 0.0055 & 0.16 & 3.8 & 15 & $\cdots$ \\
\hline & ${ }^{18} \mathrm{O}$ & $\ldots$ & 0.0088 & 0.18 & 3.5 & 14 & $\cdots$ \\
\hline & ${ }^{18} \mathrm{~F}$ & $\ldots$ & 0.0090 & 0.18 & 3.6 & 14 & $\cdots$ \\
\hline & ${ }^{19} \mathrm{~F}$ & $\ldots$ & 0.016 & 0.20 & 3.2 & 12 & $\cdots$ \\
\hline \multirow[t]{4}{*}{${ }^{17} \mathrm{~F}(\mathrm{p}, \gamma){ }^{18} \mathrm{Ne}$} & ${ }^{17} \mathrm{O}$ & $\ldots$ & 0.58 & 0.94 & 1.1 & 1.0 & $\ldots$ \\
\hline & ${ }^{18} \mathrm{O}$ & $\cdots$ & 0.56 & 0.94 & 1.1 & 1.0 & $\ldots$ \\
\hline & ${ }^{18} \mathrm{~F}$ & $\ldots$ & 0.57 & 0.95 & 1.0 & 1.0 & $\ldots$ \\
\hline & ${ }^{19} \mathrm{~F}$ & $\ldots$ & 0.55 & 0.93 & 1.0 & 1.0 & $\ldots$ \\
\hline${ }^{18} \mathrm{~F}(\mathrm{p}, \gamma){ }^{19} \mathrm{Ne}$ & ${ }^{19} \mathrm{~F}$ & $\ldots$ & 8.1 & 1.9 & 0.60 & 0.28 & $\cdots$ \\
\hline \multirow[t]{3}{*}{${ }^{18} \mathrm{~F}(\mathrm{p}, \alpha){ }^{15} \mathrm{O}$} & ${ }^{18} \mathrm{O}$ & 0.013 & 0.12 & 0.54 & 1.8 & 7.6 & 110 \\
\hline & ${ }^{18} \mathrm{~F}$ & 0.013 & 0.13 & 0.57 & 1.9 & 8.1 & 110 \\
\hline & ${ }^{19} \mathrm{~F}$ & 0.010 & 0.10 & 0.51 & 2.0 & 9.7 & 150 \\
\hline${ }^{19} \mathrm{~F}(\mathrm{p}, \alpha){ }^{16} \mathrm{O}$ & ${ }^{19} \mathrm{~F}$ & $\ldots$ & $\ldots$ & 0.68 & 1.5 & $\ldots$ & $\ldots$ \\
\hline \multirow[t]{10}{*}{${ }^{20} \mathrm{Ne}(\mathrm{p}, \gamma)^{21} \mathrm{Na}$} & ${ }^{21} \mathrm{Ne}$ & $\ldots$ & $\ldots$ & 1.8 & 0.52 & $\cdots$ & $\cdots$ \\
\hline & ${ }^{22} \mathrm{Na}$ & $\cdots$ & $\ldots$ & 1.7 & 0.52 & $\cdots$ & $\ldots$ \\
\hline & ${ }^{23} \mathrm{Na}$ & $\ldots$ & $\ldots$ & 1.8 & 0.54 & $\ldots$ & $\ldots$ \\
\hline & ${ }^{24} \mathrm{Mg}$ & $\cdots$ & $\cdots$ & 1.9 & 0.53 & $\cdots$ & $\cdots$ \\
\hline & ${ }^{25} \mathrm{Mg}$ & $\ldots$ & $\ldots$ & 1.8 & 0.54 & $\ldots$ & $\ldots$ \\
\hline & ${ }^{26} \mathrm{Mg}$ & $\ldots$ & $\ldots$ & 1.8 & 0.55 & $\ldots$ & $\cdots$ \\
\hline & ${ }^{26} \mathrm{Al}$ & $\ldots$ & $\ldots$ & 1.8 & 0.53 & $\ldots$ & $\ldots$ \\
\hline & ${ }^{27} \mathrm{Al}$ & $\ldots$ & $\ldots$ & 1.8 & 0.52 & $\cdots$ & $\cdots$ \\
\hline & ${ }^{28} \mathrm{Si}$ & $\ldots$ & $\ldots$ & 1.2 & 0.86 & $\ldots$ & $\ldots$ \\
\hline & ${ }^{29} \mathrm{Si}$ & $\ldots$ & $\ldots$ & 1.3 & 0.87 & $\cdots$ & $\cdots$ \\
\hline${ }^{21} \mathrm{Ne}(\mathrm{p}, \gamma){ }^{22} \mathrm{Na}$ & ${ }^{21} \mathrm{Ne}$ & $\ldots$ & $\ldots$ & 0.45 & 2.3 & $\ldots$ & $\ldots$ \\
\hline${ }^{22} \mathrm{Ne}(\mathrm{p}, \gamma)^{23} \mathrm{Na}$ & ${ }^{22} \mathrm{Ne}$ & 0.0000064 & 0.0000071 & 0.13 & 2.8 & 6.4 & $\cdots$ \\
\hline${ }^{21} \mathrm{Na}(\mathrm{p}, \gamma)^{22} \mathrm{Mg}$ & ${ }^{21} \mathrm{Ne}$ & 0.76 & 0.90 & 0.98 & 1.0 & 1.0 & 1.0 \\
\hline
\end{tabular}


Table 8-Continued

\begin{tabular}{|c|c|c|c|c|c|c|c|}
\hline \multirow[t]{2}{*}{ Reaction } & \multirow[t]{2}{*}{ Isotope i } & \multicolumn{6}{|c|}{ Reaction rate multiplied by } \\
\hline & & 100 & 10 & 2 & 0.5 & 0.1 & 0.01 \\
\hline & ${ }^{22} \mathrm{Na}$ & 0.77 & 0.83 & 0.91 & 1.0 & 1.1 & 1.1 \\
\hline & ${ }^{25} \mathrm{Mg}$ & 1.0 & 1.0 & 1.0 & 1.0 & 1.1 & 1.3 \\
\hline & ${ }^{26} \mathrm{Mg}$ & 1.0 & 1.0 & 1.0 & 1.0 & 1.1 & 1.3 \\
\hline & ${ }^{26} \mathrm{Al}$ & 1.0 & 1.0 & 1.0 & 1.0 & 1.1 & 1.3 \\
\hline & ${ }^{27} \mathrm{Al}$ & 1.0 & 1.0 & 1.0 & 1.0 & 1.0 & 1.2 \\
\hline${ }^{22} \mathrm{Na}(\mathrm{p}, \gamma)^{23} \mathrm{Mg}$ & ${ }^{22} \mathrm{Na}$ & $\cdots$ & $\cdots$ & 0.66 & 1.6 & $\cdots$ & $\cdots$ \\
\hline \multirow{15}{*}{${ }^{23} \mathrm{Na}(\mathrm{p}, \gamma){ }^{24} \mathrm{Mg}$} & ${ }^{20} \mathrm{Ne}$ & $\cdots$ & 0.81 & 0.94 & 1.1 & 1.2 & 1.2 \\
\hline & ${ }^{21} \mathrm{Ne}$ & $\ldots$ & 0.81 & 0.93 & 1.0 & 1.1 & 1.1 \\
\hline & ${ }^{22} \mathrm{Na}$ & $\cdots$ & 0.78 & 0.91 & 1.1 & 1.0 & 1.2 \\
\hline & ${ }^{23} \mathrm{Na}$ & $\ldots$ & 0.29 & 0.75 & 1.2 & 1.4 & 1.5 \\
\hline & ${ }^{24} \mathrm{Mg}$ & $\cdots$ & 2.7 & 1.5 & 0.60 & 0.15 & 0.015 \\
\hline & ${ }^{25} \mathrm{Mg}$ & $\cdots$ & 2.3 & 1.4 & 0.63 & 0.16 & 0.016 \\
\hline & ${ }^{26} \mathrm{Mg}$ & $\cdots$ & 2.1 & 1.4 & 0.65 & 0.16 & 0.017 \\
\hline & ${ }^{26} \mathrm{Al}$ & $\ldots$ & 2.1 & 1.4 & 0.63 & 0.16 & 0.017 \\
\hline & ${ }^{27} \mathrm{Al}$ & $\ldots$ & 2.0 & 1.4 & 0.63 & 0.17 & 0.017 \\
\hline & ${ }^{28} \mathrm{Si}$ & $\ldots$ & 1.6 & 1.2 & 0.83 & 0.62 & 0.57 \\
\hline & ${ }^{29} \mathrm{Si}$ & $\cdots$ & 1.5 & 1.1 & 0.84 & 0.66 & 0.60 \\
\hline & ${ }^{30} \mathrm{Si}$ & $\ldots$ & 1.5 & 1.2 & 0.88 & 0.75 & 0.72 \\
\hline & ${ }^{31} \mathrm{P}$ & $\ldots$ & 1.4 & 1.1 & 0.88 & 0.79 & 0.75 \\
\hline & ${ }^{32} \mathrm{~S}$ & $\ldots$ & 1.3 & 1.1 & 0.93 & 0.83 & 0.83 \\
\hline & ${ }^{33} \mathrm{~S}$ & $\ldots$ & 1.2 & 1.1 & 0.95 & 0.89 & 0.88 \\
\hline \multirow[t]{8}{*}{${ }^{23} \mathrm{Na}(\mathrm{p}, \alpha)^{20} \mathrm{Ne}$} & ${ }^{23} \mathrm{Na}$ & $\cdots$ & $\ldots$ & 0.63 & 1.4 & $\ldots$ & $\cdots$ \\
\hline & ${ }^{24} \mathrm{Mg}$ & $\cdots$ & $\ldots$ & 0.62 & 1.5 & $\cdots$ & $\ldots$ \\
\hline & ${ }^{25} \mathrm{Mg}$ & $\cdots$ & $\ldots$ & 0.64 & 1.4 & $\ldots$ & $\cdots$ \\
\hline & ${ }^{26} \mathrm{Mg}$ & $\ldots$ & $\cdots$ & 0.65 & 1.4 & $\cdots$ & $\cdots$ \\
\hline & ${ }^{26} \mathrm{Al}$ & $\ldots$ & $\ldots$ & 0.64 & 1.4 & $\cdots$ & $\cdots$ \\
\hline & ${ }^{27} \mathrm{Al}$ & $\ldots$ & $\ldots$ & 0.63 & 1.4 & $\ldots$ & $\ldots$ \\
\hline & ${ }^{28} \mathrm{Si}$ & $\ldots$ & $\ldots$ & 0.84 & 1.2 & $\ldots$ & $\ldots$ \\
\hline & ${ }^{29} \mathrm{Si}$ & $\ldots$ & $\ldots$ & 0.85 & 1.1 & $\ldots$ & $\ldots$ \\
\hline \multirow[t]{3}{*}{${ }^{25} \mathrm{Mg}(\mathrm{p}, \gamma)^{26} \mathrm{Al}^{g}$} & ${ }^{25} \mathrm{Mg}$ & $\cdots$ & $\cdots$ & 0.64 & 1.5 & $\cdots$ & $\cdots$ \\
\hline & ${ }^{26} \mathrm{Mg}$ & $\ldots$ & $\ldots$ & 0.58 & 1.6 & $\ldots$ & $\ldots$ \\
\hline & ${ }^{26} \mathrm{Al}$ & $\cdots$ & $\ldots$ & 1.2 & 0.80 & $\ldots$ & $\cdots$ \\
\hline${ }^{25} \mathrm{Mg}(\mathrm{p}, \gamma){ }^{26} \mathrm{Al}^{m}$ & ${ }^{26} \mathrm{Mg}$ & $\ldots$ & $\ldots$ & 1.8 & 0.55 & $\ldots$ & \\
\hline${ }^{26} \mathrm{Mg}(\mathrm{p}, \gamma){ }^{27} \mathrm{Al}$ & ${ }^{26} \mathrm{Mg}$ & $\cdots$ & 0.12 & 0.55 & 1.8 & $\cdots$ & $\cdots$ \\
\hline \multirow[t]{2}{*}{${ }^{26} \mathrm{Al}^{g}(\mathrm{p}, \gamma)^{27} \mathrm{Si}$} & ${ }^{26} \mathrm{Al}$ & $\cdots$ & 0.062 & 0.38 & 2.7 & $\cdots$ & $\cdots$ \\
\hline & ${ }^{27} \mathrm{Al}$ & $\ldots$ & 0.86 & 0.92 & 1.1 & $\cdots$ & $\cdots$ \\
\hline${ }^{26} \mathrm{Al}^{m}(\mathrm{p}, \gamma){ }^{27} \mathrm{Si}$ & ${ }^{26} \mathrm{Mg}$ & 0.26 & 0.74 & 0.97 & 1.0 & 1.1 & 1.1 \\
\hline${ }^{27} \mathrm{Al}(\mathrm{p}, \gamma){ }^{28} \mathrm{Si}$ & ${ }^{27} \mathrm{Al}$ & $\ldots$ & $\cdots$ & 0.42 & 2.3 & $\ldots$ & $\ldots$ \\
\hline \multirow[t]{6}{*}{${ }^{28} \mathrm{Si}(\mathrm{p}, \gamma){ }^{29} \mathrm{P}$} & ${ }^{28} \mathrm{Si}$ & $\ldots$ & $\cdots$ & 0.78 & 1.1 & $\cdots$ & $\ldots$ \\
\hline & ${ }^{29} \mathrm{Si}$ & $\cdots$ & $\cdots$ & 1.6 & 0.56 & $\cdots$ & $\cdots$ \\
\hline & ${ }^{30} \mathrm{Si}$ & $\cdots$ & $\cdots$ & 1.7 & 0.55 & $\cdots$ & $\cdots$ \\
\hline & ${ }^{31} \mathrm{P}$ & $\cdots$ & $\cdots$ & 1.8 & 0.54 & $\cdots$ & $\cdots$ \\
\hline & ${ }^{32} \mathrm{~S}$ & $\ldots$ & $\cdots$ & 1.8 & 0.56 & $\ldots$ & $\cdots$ \\
\hline & ${ }^{33} \mathrm{~S}$ & $\ldots$ & $\cdots$ & 1.6 & 0.67 & $\cdots$ & $\ldots$ \\
\hline \multirow[t]{3}{*}{${ }^{29} \mathrm{Si}(\mathrm{p}, \gamma){ }^{30} \mathrm{P}$} & ${ }^{29} \mathrm{Si}$ & $\cdots$ & 0.074 & 0.47 & 2.1 & 9.4 & $\cdots$ \\
\hline & ${ }^{30} \mathrm{Si}$ & $\cdots$ & 1.0 & 1.0 & 1.0 & 0.68 & $\ldots$ \\
\hline & ${ }^{31} \mathrm{P}$ & $\ldots$ & 1.0 & 1.0 & 0.94 & 0.60 & $\ldots$ \\
\hline
\end{tabular}


Table 8-Continued

\begin{tabular}{|c|c|c|c|c|c|c|c|}
\hline \multirow[t]{2}{*}{ Reaction } & \multirow[t]{2}{*}{ Isotope i } & \multicolumn{6}{|c|}{ Reaction rate multiplied by } \\
\hline & & 100 & 10 & 2 & 0.5 & 0.1 & 0.01 \\
\hline \multirow{4}{*}{${ }^{30} \mathrm{Si}(\mathrm{p}, \gamma){ }^{31} \mathrm{P}$} & ${ }^{32} \mathrm{~S}$ & $\cdots$ & 1.1 & 1.0 & 0.93 & 0.51 & $\cdots$ \\
\hline & ${ }^{33} \mathrm{~S}$ & $\ldots$ & 1.1 & 1.0 & 0.91 & 0.60 & $\ldots$ \\
\hline & ${ }^{30} \mathrm{Si}$ & $\ldots$ & 0.88 & 1.0 & 1.0 & 1.0 & $\ldots$ \\
\hline & ${ }^{31} \mathrm{P}$ & $\ldots$ & 1.2 & 1.0 & 0.98 & 0.96 & $\ldots$ \\
\hline \multirow[t]{5}{*}{${ }^{30} \mathrm{P}(\mathrm{p}, \gamma){ }^{31} \mathrm{~S}$} & ${ }^{30} \mathrm{Si}$ & 0.022 & 0.17 & 0.66 & 1.3 & 1.6 & 1.8 \\
\hline & ${ }^{31} \mathrm{P}$ & 1.9 & 1.8 & 1.3 & 0.63 & 0.19 & 0.058 \\
\hline & ${ }^{32} \mathrm{~S}$ & 2.4 & 2.2 & 1.5 & 0.63 & 0.20 & 0.083 \\
\hline & ${ }^{33} \mathrm{~S}$ & 2.5 & 2.2 & 1.4 & 0.72 & 0.41 & 0.32 \\
\hline & ${ }^{34} \mathrm{~S}$ & 1.3 & 1.2 & 1.1 & 0.92 & 0.92 & 0.92 \\
\hline \multirow[t]{3}{*}{${ }^{31} \mathrm{P}(\mathrm{p}, \alpha){ }^{28} \mathrm{Si}$} & ${ }^{31} \mathrm{P}$ & $\ldots$ & 0.69 & 0.94 & 1.0 & $\ldots$ & $\ldots$ \\
\hline & ${ }^{32} \mathrm{~S}$ & $\ldots$ & 0.76 & 0.98 & 1.0 & $\ldots$ & $\ldots$ \\
\hline & ${ }^{33} \mathrm{~S}$ & $\ldots$ & 0.85 & 0.98 & 1.0 & $\ldots$ & $\ldots$ \\
\hline \multirow[t]{2}{*}{${ }^{32} \mathrm{~S}(\mathrm{p}, \gamma)^{33} \mathrm{Cl}$} & ${ }^{33} \mathrm{~S}$ & $\ldots$ & $\ldots$ & 1.8 & 0.59 & $\cdots$ & $\cdots$ \\
\hline & ${ }^{34} \mathrm{~S}$ & $\ldots$ & $\ldots$ & 1.2 & 0.92 & $\ldots$ & $\ldots$ \\
\hline \multirow[t]{3}{*}{${ }^{33} \mathrm{~S}(\mathrm{p}, \gamma){ }^{34} \mathrm{Cl}$} & ${ }^{33} \mathrm{~S}$ & 0.0057 & 0.18 & 0.71 & 1.2 & 1.5 & 1.6 \\
\hline & ${ }^{34} \mathrm{~S}$ & 1.5 & 1.4 & 1.2 & 0.92 & 0.75 & 0.72 \\
\hline & ${ }^{35} \mathrm{Cl}$ & 1.2 & 1.1 & 1.0 & 1.0 & 0.95 & 0.95 \\
\hline \multirow[t]{2}{*}{${ }^{34} \mathrm{~S}(\mathrm{p}, \gamma){ }^{35} \mathrm{Cl}$} & ${ }^{34} \mathrm{~S}$ & 0.0077 & 0.072 & 0.48 & 1.5 & 2.2 & 2.4 \\
\hline & ${ }^{35} \mathrm{Cl}$ & 1.5 & 1.5 & 1.3 & 0.73 & 0.32 & 0.21 \\
\hline \multirow[t]{3}{*}{${ }^{36} \operatorname{Ar}(\mathrm{p}, \gamma){ }^{37} \mathrm{~K}$} & ${ }^{36} \mathrm{Ar}$ & $\ldots$ & $\cdots$ & 0.30 & 1.7 & $\cdots$ & $\cdots$ \\
\hline & ${ }^{37} \mathrm{Ar}$ & $\ldots$ & $\ldots$ & 1.3 & 0.65 & $\ldots$ & $\ldots$ \\
\hline & ${ }^{38} \mathrm{Ar}$ & $\ldots$ & $\ldots$ & 1.2 & 0.82 & $\ldots$ & $\ldots$ \\
\hline \multirow[t]{4}{*}{${ }^{37} \operatorname{Ar}(\mathrm{p}, \gamma){ }^{38} \mathrm{~K}$} & ${ }^{37} \mathrm{Ar}$ & 0.062 & 0.62 & 0.96 & 1.0 & 1.1 & 1.1 \\
\hline & ${ }^{38} \mathrm{Ar}$ & 8.2 & 4.1 & 1.5 & 0.76 & 0.56 & 0.53 \\
\hline & ${ }^{37} \mathrm{Cl}$ & 0.87 & 0.93 & 1.0 & 1.0 & 1.0 & 1.0 \\
\hline & ${ }^{39} \mathrm{~K}$ & 1.5 & 1.2 & 1.0 & 0.98 & 0.97 & 0.97 \\
\hline \multirow[t]{2}{*}{${ }^{38} \operatorname{Ar}(\mathrm{p}, \gamma){ }^{39} \mathrm{~K}$} & ${ }^{38} \mathrm{Ar}$ & 0.41 & 0.71 & 0.97 & 1.0 & 1.1 & 1.1 \\
\hline & ${ }^{39} \mathrm{~K}$ & 4.1 & 2.6 & 1.2 & 0.86 & 0.76 & 0.73 \\
\hline \multirow[t]{2}{*}{${ }^{38} \mathrm{~K}(\mathrm{p}, \gamma){ }^{39} \mathrm{Ca}$} & ${ }^{38} \mathrm{Ar}$ & 0.79 & 0.97 & 1.0 & 1.0 & 1.0 & 1.0 \\
\hline & ${ }^{39} \mathrm{~K}$ & 2.1 & 1.2 & 1.0 & 0.98 & 0.98 & 0.98 \\
\hline${ }^{39} \mathrm{~K}(\mathrm{p}, \gamma){ }^{40} \mathrm{Ca}$ & ${ }^{39} \mathrm{~K}$ & 0.12 & 0.77 & 0.97 & 1.0 & 1.0 & 1.0 \\
\hline
\end{tabular}

NOTE.- See $\S 4$ for an explanation of the quantities listed here. 
Table 9. FINAL ABUNDANCE CHANGES $\mathrm{X}_{i} / \mathrm{X}_{i \text {,rec }}$ RESULTING FROM REACTION RATE VARIATIONS FOR ONe NOVA MODEL JCH2 $\left(\mathrm{T}_{P E A K}=0.251 \mathrm{GK}\right)$

\begin{tabular}{|c|c|c|c|c|c|c|c|}
\hline \multirow[t]{2}{*}{ Reaction } & \multirow[t]{2}{*}{ Isotope i } & \multicolumn{6}{|c|}{ Reaction rate multiplied by } \\
\hline & & 100 & 10 & 2 & 0.5 & 0.1 & 0.01 \\
\hline${ }^{3} \mathrm{He}(\alpha, \gamma)^{7} \mathrm{Be}$ & ${ }^{7} \mathrm{Be}$ & $\ldots$ & & 0.33 & 1.5 & $\ldots$ & $\ldots$ \\
\hline${ }^{7} \mathrm{Be}(\mathrm{p}, \gamma)^{8} \mathrm{~B}$ & ${ }^{7} \mathrm{Be}$ & $\ldots$ & $\ldots$ & 0.048 & 6.7 & $\ldots$ & $\ldots$ \\
\hline${ }^{8} \mathrm{~B}(\mathrm{p}, \gamma){ }^{9} \mathrm{C}$ & ${ }^{7} \mathrm{Be}$ & $\ldots$ & 0.46 & 0.89 & 1.1 & 1.2 & $\ldots$ \\
\hline \multirow[t]{2}{*}{${ }^{13} \mathrm{~N}(\mathrm{p}, \gamma){ }^{14} \mathrm{O}$} & ${ }^{13} \mathrm{C}$ & $\ldots$ & $\ldots$ & 0.72 & 1.3 & $\ldots$ & $\ldots$ \\
\hline & ${ }^{14} \mathrm{~N}$ & $\ldots$ & $\ldots$ & 1.1 & 0.84 & $\ldots$ & $\ldots$ \\
\hline${ }^{14} \mathrm{~N}(\mathrm{p}, \gamma){ }^{15} \mathrm{O}$ & ${ }^{14} \mathrm{~N}$ & $\ldots$ & $\ldots$ & 0.81 & 1.2 & $\ldots$ & $\ldots$ \\
\hline${ }^{15} \mathrm{~N}(\mathrm{p}, \gamma)^{16} \mathrm{O}$ & ${ }^{16} \mathrm{O}$ & $\ldots$ & $\ldots$ & 1.4 & 0.76 & $\cdots$ & $\cdots$ \\
\hline \multirow[t]{2}{*}{${ }^{15} \mathrm{~N}(\mathrm{p}, \alpha)^{12} \mathrm{C}$} & ${ }^{15} \mathrm{~N}$ & $\ldots$ & $\ldots$ & 0.64 & 1.5 & $\ldots$ & $\ldots$ \\
\hline & ${ }^{16} \mathrm{O}$ & $\ldots$ & $\ldots$ & 0.76 & 1.4 & $\ldots$ & $\ldots$ \\
\hline${ }^{16} \mathrm{O}(\mathrm{p}, \gamma){ }^{17} \mathrm{~F}$ & ${ }^{16} \mathrm{O}$ & $\ldots$ & $\ldots$ & 0.40 & 16 & $\ldots$ & $\ldots$ \\
\hline \multirow[t]{4}{*}{${ }^{17} \mathrm{O}(\mathrm{p}, \gamma){ }^{18} \mathrm{~F}$} & ${ }^{17} \mathrm{O}$ & $\ldots$ & 0.19 & 0.70 & 1.2 & 1.4 & $\ldots$ \\
\hline & ${ }^{18} \mathrm{~F}$ & $\ldots$ & 1.9 & 1.5 & 0.60 & 0.14 & $\ldots$ \\
\hline & ${ }^{18} \mathrm{O}$ & $\ldots$ & 1.8 & 1.4 & 0.59 & 0.14 & $\ldots$ \\
\hline & ${ }^{19} \mathrm{~F}$ & $\ldots$ & 1.5 & 1.3 & 0.58 & 0.14 & $\ldots$ \\
\hline \multirow[t]{4}{*}{${ }^{17} \mathrm{O}(\mathrm{p}, \alpha)^{14} \mathrm{~N}$} & ${ }^{17} \mathrm{O}$ & $\ldots$ & 0.033 & 0.26 & 2.9 & 9.5 & $\ldots$ \\
\hline & ${ }^{18} \mathrm{~F}$ & $\ldots$ & 0.031 & 0.27 & 2.9 & 9.5 & $\ldots$ \\
\hline & ${ }^{18} \mathrm{O}$ & $\ldots$ & 0.030 & 0.26 & 2.8 & 8.6 & $\ldots$ \\
\hline & ${ }^{19} \mathrm{~F}$ & $\ldots$ & 0.028 & 0.27 & 2.6 & 7.7 & $\ldots$ \\
\hline \multirow[t]{4}{*}{${ }^{17} \mathrm{~F}(\mathrm{p}, \gamma){ }^{18} \mathrm{Ne}$} & ${ }^{17} \mathrm{O}$ & $\ldots$ & 0.17 & 0.80 & 1.1 & 1.3 & $\ldots$ \\
\hline & ${ }^{18} \mathrm{~F}$ & $\ldots$ & 0.17 & 0.80 & 1.2 & 1.3 & $\ldots$ \\
\hline & ${ }^{18} \mathrm{O}$ & $\ldots$ & 0.16 & 0.79 & 1.1 & 1.2 & $\ldots$ \\
\hline & ${ }^{19} \mathrm{~F}$ & $\ldots$ & 0.15 & 0.76 & 1.1 & 1.2 & $\ldots$ \\
\hline \multirow[t]{2}{*}{${ }^{18} \mathrm{~F}(\mathrm{p}, \gamma){ }^{19} \mathrm{Ne}$} & ${ }^{16} \mathrm{O}$ & $\ldots$ & 1.2 & 1.0 & 1.0 & 1.0 & $\ldots$ \\
\hline & ${ }^{19} \mathrm{~F}$ & $\ldots$ & 9.2 & 1.9 & 0.49 & 0.13 & $\cdots$ \\
\hline \multirow[t]{4}{*}{${ }^{18} \mathrm{~F}(\mathrm{p}, \alpha){ }^{15} \mathrm{O}$} & ${ }^{16} \mathrm{O}$ & 0.95 & 1.0 & 1.0 & 1.0 & 1.2 & 3.3 \\
\hline & ${ }^{18} \mathrm{~F}$ & 0.014 & 0.14 & 0.55 & 1.9 & 8.5 & 110 \\
\hline & ${ }^{18} \mathrm{O}$ & 0.014 & 0.13 & 0.53 & 1.8 & 7.9 & 100 \\
\hline & ${ }^{19} \mathrm{~F}$ & 0.010 & 0.10 & 0.48 & 1.9 & 9.2 & 130 \\
\hline \multirow[t]{14}{*}{${ }^{20} \mathrm{Ne}(\mathrm{p}, \gamma){ }^{21} \mathrm{Na}$} & ${ }^{20} \mathrm{Ne}$ & $\ldots$ & & 0.87 & 1.1 & $\cdots$ & $\cdots$ \\
\hline & ${ }^{21} \mathrm{Ne}$ & $\ldots$ & $\cdots$ & 1.7 & 0.53 & $\cdots$ & $\cdots$ \\
\hline & ${ }^{22} \mathrm{Na}$ & $\ldots$ & $\ldots$ & 1.7 & 0.56 & $\cdots$ & $\cdots$ \\
\hline & ${ }^{22} \mathrm{Ne}$ & $\ldots$ & $\ldots$ & 1.2 & 0.93 & $\cdots$ & $\cdots$ \\
\hline & ${ }^{23} \mathrm{Na}$ & $\ldots$ & $\ldots$ & 1.7 & 0.55 & $\cdots$ & $\ldots$ \\
\hline & ${ }^{24} \mathrm{Mg}$ & $\ldots$ & $\ldots$ & 1.7 & 0.57 & $\ldots$ & $\ldots$ \\
\hline & ${ }^{25} \mathrm{Mg}$ & $\ldots$ & $\ldots$ & 1.6 & 0.54 & $\cdots$ & $\ldots$ \\
\hline & ${ }^{26} \mathrm{Al}$ & $\cdots$ & $\cdots$ & 1.7 & 0.53 & $\cdots$ & $\ldots$ \\
\hline & ${ }^{26} \mathrm{Mg}$ & $\ldots$ & $\ldots$ & 1.7 & 0.56 & $\cdots$ & $\cdots$ \\
\hline & ${ }^{27} \mathrm{Al}$ & $\ldots$ & $\cdots$ & 1.8 & 0.54 & $\cdots$ & $\cdots$ \\
\hline & ${ }^{28} \mathrm{Si}$ & $\ldots$ & $\ldots$ & 1.4 & 0.73 & $\cdots$ & $\ldots$ \\
\hline & ${ }^{29} \mathrm{Si}$ & $\ldots$ & & 1.4 & 0.74 & $\cdots$ & $\cdots$ \\
\hline & ${ }^{30} \mathrm{Si}$ & $\ldots$ & $\ldots$ & 1.2 & 0.80 & $\ldots$ & $\ldots$ \\
\hline & ${ }^{31} \mathrm{P}$ & $\ldots$ & $\ldots$ & 1.1 & 0.90 & $\cdots$ & $\ldots$ \\
\hline${ }^{22} \mathrm{Ne}(\mathrm{p}, \gamma)^{23} \mathrm{Na}$ & ${ }^{22} \mathrm{Ne}$ & 0.00014 & 0.00016 & 0.0035 & 19 & 220 & $\ldots$ \\
\hline \multirow[t]{2}{*}{${ }^{21} \mathrm{Na}(\mathrm{p}, \gamma){ }^{22} \mathrm{Mg}$} & ${ }^{21} \mathrm{Ne}$ & 0.35 & 0.57 & 0.83 & 1.2 & 1.4 & 1.5 \\
\hline & ${ }^{22} \mathrm{Na}$ & 0.72 & 0.76 & 0.90 & 1.1 & 1.4 & 1.5 \\
\hline${ }^{22} \mathrm{Na}(\mathrm{p}, \gamma)^{23} \mathrm{Mg}$ & ${ }^{22} \mathrm{Na}$ & $\ldots$ & $\ldots$ & 0.72 & 1.6 & $\cdots$ & $\cdots$ \\
\hline${ }^{23} \mathrm{Na}(\mathrm{p}, \gamma){ }^{24} \mathrm{Mg}$ & ${ }^{20} \mathrm{Ne}$ & $\ldots$ & 0.73 & 0.87 & 1.1 & 1.2 & 1.3 \\
\hline
\end{tabular}


Table 9-Continued

\begin{tabular}{|c|c|c|c|c|c|c|c|}
\hline \multirow[t]{2}{*}{ Reaction } & \multirow[t]{2}{*}{ Isotope i } & \multicolumn{6}{|c|}{ Reaction rate multiplied by } \\
\hline & & 100 & 10 & 2 & 0.5 & 0.1 & 0.01 \\
\hline & ${ }^{21} \mathrm{Ne}$ & $\ldots$ & 0.73 & 0.89 & 1.1 & 1.2 & 1.2 \\
\hline & ${ }^{22} \mathrm{Na}$ & $\cdots$ & 0.71 & 0.90 & 1.1 & 1.3 & 1.3 \\
\hline & ${ }^{22} \mathrm{Ne}$ & $\cdots$ & 1.1 & 1.0 & 0.93 & 0.89 & 0.89 \\
\hline & ${ }^{23} \mathrm{Na}$ & $\ldots$ & 0.31 & 0.73 & 1.2 & 1.5 & 1.6 \\
\hline & ${ }^{24} \mathrm{Mg}$ & $\cdots$ & 2.7 & 1.5 & 0.62 & 0.16 & 0.017 \\
\hline & ${ }^{25} \mathrm{Mg}$ & $\cdots$ & 1.9 & 1.4 & 0.65 & 0.16 & 0.018 \\
\hline & ${ }^{26} \mathrm{Al}$ & $\cdots$ & 1.8 & 1.4 & 0.64 & 0.16 & 0.018 \\
\hline & ${ }^{26} \mathrm{Mg}$ & $\ldots$ & 1.9 & 1.3 & 0.67 & 0.17 & 0.019 \\
\hline & ${ }^{27} \mathrm{Al}$ & $\cdots$ & 1.8 & 1.3 & 0.66 & 0.18 & 0.020 \\
\hline & ${ }^{28} \mathrm{Si}$ & $\ldots$ & 1.6 & 1.2 & 0.76 & 0.46 & 0.36 \\
\hline & ${ }^{29} \mathrm{Si}$ & $\ldots$ & 1.7 & 1.2 & 0.77 & 0.47 & 0.37 \\
\hline & ${ }^{30} \mathrm{Si}$ & $\cdots$ & 1.5 & 1.1 & 0.80 & 0.61 & 0.54 \\
\hline & ${ }^{31} \mathrm{P}$ & $\ldots$ & 1.5 & 1.1 & 1.0 & 0.68 & 0.63 \\
\hline & ${ }^{32} \mathrm{~S}$ & $\cdots$ & 1.4 & 1.1 & 1.0 & 0.80 & 0.77 \\
\hline & ${ }^{33} \mathrm{~S}$ & $\ldots$ & 1.3 & 1.1 & 1.0 & 0.81 & 0.81 \\
\hline & ${ }^{34} \mathrm{~S}$ & $\ldots$ & 1.3 & 1.1 & 1.0 & 0.88 & 0.88 \\
\hline \multirow[t]{12}{*}{${ }^{23} \mathrm{Na}(\mathrm{p}, \alpha){ }^{20} \mathrm{Ne}$} & ${ }^{20} \mathrm{Ne}$ & $\ldots$ & $\ldots$ & 1.1 & 0.87 & $\ldots$ & $\ldots$ \\
\hline & ${ }^{21} \mathrm{Ne}$ & $\ldots$ & $\ldots$ & 1.1 & 0.90 & $\cdots$ & $\cdots$ \\
\hline & ${ }^{22} \mathrm{Na}$ & $\ldots$ & $\ldots$ & 1.1 & 0.90 & $\ldots$ & $\ldots$ \\
\hline & ${ }^{23} \mathrm{Na}$ & $\cdots$ & $\ldots$ & 0.73 & 1.3 & $\ldots$ & $\cdots$ \\
\hline & ${ }^{24} \mathrm{Mg}$ & $\ldots$ & $\ldots$ & 0.68 & 1.4 & $\ldots$ & $\ldots$ \\
\hline & ${ }^{25} \mathrm{Mg}$ & $\cdots$ & $\cdots$ & 0.65 & 1.4 & $\cdots$ & $\cdots$ \\
\hline & ${ }^{26} \mathrm{Al}$ & $\cdots$ & $\cdots$ & 0.64 & 1.4 & $\ldots$ & $\ldots$ \\
\hline & ${ }^{26} \mathrm{Mg}$ & $\cdots$ & $\cdots$ & 0.67 & 1.3 & $\ldots$ & $\cdots$ \\
\hline & ${ }^{27} \mathrm{Al}$ & $\ldots$ & $\ldots$ & 0.66 & 1.3 & $\ldots$ & $\ldots$ \\
\hline & ${ }^{28} \mathrm{Si}$ & $\cdots$ & $\ldots$ & 0.76 & 1.2 & $\cdots$ & \\
\hline & ${ }^{29} \mathrm{Si}$ & $\ldots$ & $\ldots$ & 0.77 & 1.2 & $\ldots$ & $\ldots$ \\
\hline & ${ }^{30} \mathrm{Si}$ & $\ldots$ & $\ldots$ & 0.80 & 1.1 & $\ldots$ & $\ldots$ \\
\hline \multirow[t]{13}{*}{${ }^{23} \mathrm{Mg}(\mathrm{p}, \gamma)^{24} \mathrm{Al}$} & ${ }^{20} \mathrm{Ne}$ & 0.87 & 1.0 & 1.0 & 1.0 & 1.0 & 1.0 \\
\hline & ${ }^{21} \mathrm{Ne}$ & 0.90 & 1.0 & 1.0 & 1.0 & 1.0 & 1.0 \\
\hline & ${ }^{22} \mathrm{Na}$ & 0.90 & 1.0 & 1.0 & 1.0 & 1.0 & 1.0 \\
\hline & ${ }^{23} \mathrm{Na}$ & 0.87 & 1.0 & 1.0 & 1.0 & 1.0 & 1.0 \\
\hline & ${ }^{24} \mathrm{Mg}$ & 0.90 & 1.0 & 1.0 & 1.0 & 1.0 & 1.0 \\
\hline & ${ }^{25} \mathrm{Mg}$ & 0.90 & 1.0 & 1.0 & 1.0 & 1.0 & 1.0 \\
\hline & ${ }^{26} \mathrm{Al}$ & 0.88 & 1.0 & 1.0 & 1.0 & 1.0 & 1.0 \\
\hline & ${ }^{26} \mathrm{Mg}$ & 0.89 & 1.0 & 1.0 & 1.0 & 1.0 & 1.0 \\
\hline & ${ }^{27} \mathrm{Al}$ & 0.90 & 0.80 & 1.0 & 1.0 & 1.0 & 1.0 \\
\hline & ${ }^{28} \mathrm{Si}$ & 1.2 & 1.0 & 1.0 & 1.0 & 1.0 & 1.0 \\
\hline & ${ }^{29} \mathrm{Si}$ & 1.3 & 1.0 & 1.0 & 1.0 & 1.0 & 1.0 \\
\hline & ${ }^{30} \mathrm{Si}$ & 1.2 & 1.0 & 1.0 & 1.0 & 1.0 & 1.0 \\
\hline & ${ }^{31} \mathrm{P}$ & 1.3 & 1.0 & 1.0 & 1.0 & 1.0 & 1.0 \\
\hline \multirow[t]{3}{*}{${ }^{25} \mathrm{Mg}(\mathrm{p}, \gamma)^{26} \mathrm{Al}^{g}$} & ${ }^{25} \mathrm{Mg}$ & $\cdots$ & $\cdots$ & 0.60 & 1.6 & $\ldots$ & $\cdots$ \\
\hline & ${ }^{26} \mathrm{Al}$ & $\cdots$ & $\ldots$ & 1.1 & 0.81 & $\ldots$ & $\cdots$ \\
\hline & ${ }^{26} \mathrm{Mg}$ & $\cdots$ & $\cdots$ & 0.56 & 1.7 & $\cdots$ & $\cdots$ \\
\hline${ }^{25} \mathrm{Mg}(\mathrm{p}, \gamma)^{26} \mathrm{Al}^{m}$ & ${ }^{26} \mathrm{Mg}$ & $\ldots$ & $\ldots$ & 1.7 & 0.52 & $\ldots$ & $\ldots$ \\
\hline${ }^{26} \mathrm{Mg}(\mathrm{p}, \gamma){ }^{27} \mathrm{Al}$ & ${ }^{26} \mathrm{Mg}$ & $\cdots$ & 0.13 & 0.56 & 1.9 & $\cdots$ & $\cdots$ \\
\hline${ }^{26} \mathrm{Al}^{g}(\mathrm{p}, \gamma)^{27} \mathrm{Si}$ & ${ }^{26} \mathrm{Al}$ & $\cdots$ & 0.073 & 0.44 & 2.5 & $\ldots$ & $\cdots$ \\
\hline
\end{tabular}


Table 9-Continued

\begin{tabular}{|c|c|c|c|c|c|c|c|}
\hline \multirow[t]{2}{*}{ Reaction } & \multirow[t]{2}{*}{ Isotope i } & \multicolumn{6}{|c|}{ Reaction rate multiplied by } \\
\hline & & 100 & 10 & 2 & 0.5 & 0.1 & 0.01 \\
\hline${ }^{26} \mathrm{Al}^{m}(\mathrm{p}, \gamma){ }^{27} \mathrm{Si}$ & ${ }^{26} \mathrm{Mg}$ & 0.16 & 0.63 & 0.93 & 1.0 & 1.1 & 1.1 \\
\hline${ }^{27} \mathrm{Al}(\mathrm{p}, \gamma){ }^{28} \mathrm{Si}$ & ${ }^{27} \mathrm{Al}$ & $\cdots$ & $\cdots$ & 0.41 & 2.5 & $\ldots$ & $\cdots$ \\
\hline \multirow{8}{*}{${ }^{28} \mathrm{Si}(\mathrm{p}, \gamma){ }^{29} \mathrm{P}$} & ${ }^{28} \mathrm{Si}$ & $\cdots$ & $\cdots$ & 0.64 & 1.3 & $\cdots$ & $\cdots$ \\
\hline & ${ }^{29} \mathrm{Si}$ & $\ldots$ & $\ldots$ & 1.3 & 0.67 & $\cdots$ & $\cdots$ \\
\hline & ${ }^{30} \mathrm{Si}$ & $\cdots$ & $\cdots$ & 1.3 & 0.64 & $\cdots$ & $\cdots$ \\
\hline & ${ }^{31} \mathrm{P}$ & $\cdots$ & $\cdots$ & 1.4 & 0.65 & $\cdots$ & $\cdots$ \\
\hline & ${ }^{32} \mathrm{~S}$ & $\cdots$ & $\cdots$ & 1.5 & 0.60 & $\cdots$ & $\cdots$ \\
\hline & ${ }^{33} \mathrm{~S}$ & $\ldots$ & $\ldots$ & 1.6 & 0.59 & $\cdots$ & $\cdots$ \\
\hline & ${ }^{34} \mathrm{~S}$ & $\cdots$ & $\cdots$ & 1.6 & 0.59 & $\cdots$ & $\cdots$ \\
\hline & ${ }^{35} \mathrm{Cl}$ & $\ldots$ & $\ldots$ & 1.4 & 0.67 & $\cdots$ & $\ldots$ \\
\hline${ }^{29} \mathrm{Si}(\mathrm{p}, \gamma){ }^{30} \mathrm{P}$ & ${ }^{29} \mathrm{Si}$ & $\cdots$ & 0.069 & 0.45 & 2.2 & 11 & $\cdots$ \\
\hline${ }^{30} \mathrm{Si}(\mathrm{p}, \gamma){ }^{31} \mathrm{P}$ & ${ }^{30} \mathrm{Si}$ & $\ldots$ & 0.80 & 0.93 & 1.0 & 1.1 & $\ldots$ \\
\hline \multirow[t]{2}{*}{${ }^{29} \mathrm{P}(\mathrm{p}, \gamma){ }^{30} \mathrm{~S}$} & ${ }^{34} \mathrm{~S}$ & 1.2 & 1.0 & 1.0 & 1.0 & 1.0 & 1.0 \\
\hline & ${ }^{35} \mathrm{Cl}$ & 1.2 & 1.0 & 1.0 & 1.0 & 1.0 & 1.0 \\
\hline \multirow[t]{7}{*}{${ }^{30} \mathrm{P}(\mathrm{p}, \gamma){ }^{31} \mathrm{~S}$} & ${ }^{30} \mathrm{Si}$ & 0.015 & 0.13 & 0.55 & 1.6 & 2.9 & 3.4 \\
\hline & ${ }^{31} \mathrm{P}$ & 1.3 & 1.1 & 1.0 & 0.84 & 0.38 & 0.16 \\
\hline & ${ }^{32} \mathrm{~S}$ & 1.4 & 1.4 & 1.2 & 0.77 & 0.27 & 0.087 \\
\hline & ${ }^{33} \mathrm{~S}$ & 1.6 & 1.5 & 1.2 & 0.74 & 0.24 & 0.074 \\
\hline & ${ }^{34} \mathrm{~S}$ & 1.7 & 1.6 & 1.3 & 0.75 & 0.24 & 0.088 \\
\hline & ${ }^{35} \mathrm{Cl}$ & 1.7 & 1.6 & 1.3 & 0.76 & 0.39 & 0.28 \\
\hline & ${ }^{36} \mathrm{Ar}$ & 1.2 & 1.2 & 1.1 & 0.95 & 0.85 & 0.85 \\
\hline \multirow[t]{7}{*}{${ }^{31} \mathrm{P}(\mathrm{p}, \alpha){ }^{28} \mathrm{Si}$} & ${ }^{28} \mathrm{Si}$ & $\ldots$ & 1.2 & 1.0 & 1.0 & $\ldots$ & $\ldots$ \\
\hline & ${ }^{29} \mathrm{Si}$ & $\ldots$ & 1.2 & 1.0 & 1.0 & $\cdots$ & $\ldots$ \\
\hline & ${ }^{31} \mathrm{P}$ & $\cdots$ & 0.60 & 0.94 & 1.0 & $\cdots$ & $\cdots$ \\
\hline & ${ }^{32} \mathrm{~S}$ & $\ldots$ & 0.60 & 0.93 & 1.0 & $\ldots$ & $\ldots$ \\
\hline & ${ }^{33} \mathrm{~S}$ & $\cdots$ & 0.59 & 0.93 & 1.0 & $\cdots$ & $\ldots$ \\
\hline & ${ }^{34} \mathrm{~S}$ & $\ldots$ & 0.63 & 0.94 & 1.1 & $\ldots$ & \\
\hline & ${ }^{35} \mathrm{Cl}$ & $\ldots$ & 0.72 & 0.92 & 1.0 & $\cdots$ & $\ldots$ \\
\hline \multirow[t]{4}{*}{${ }^{32} \mathrm{~S}(\mathrm{p}, \gamma)^{33} \mathrm{Cl}$} & ${ }^{33} \mathrm{~S}$ & $\ldots$ & $\ldots$ & 2.0 & 0.48 & $\cdots$ & $\ldots$ \\
\hline & ${ }^{34} \mathrm{~S}$ & $\cdots$ & $\ldots$ & 2.0 & 0.51 & $\ldots$ & $\cdots$ \\
\hline & ${ }^{35} \mathrm{Cl}$ & $\cdots$ & $\ldots$ & 1.7 & 0.59 & $\ldots$ & $\ldots$ \\
\hline & ${ }^{36} \mathrm{Ar}$ & $\ldots$ & $\ldots$ & 1.2 & 0.90 & $\cdots$ & $\cdots$ \\
\hline \multirow[t]{4}{*}{${ }^{33} \mathrm{~S}(\mathrm{p}, \gamma){ }^{34} \mathrm{Cl}$} & ${ }^{33} \mathrm{~S}$ & 0.0014 & 0.085 & 0.59 & 1.3 & 1.7 & 1.9 \\
\hline & ${ }^{34} \mathrm{~S}$ & 1.8 & 1.8 & 1.4 & 0.63 & 0.17 & 0.033 \\
\hline & ${ }^{35} \mathrm{Cl}$ & 2.2 & 1.9 & 1.3 & 0.66 & 0.31 & 0.21 \\
\hline & ${ }^{36} \mathrm{Ar}$ & 1.3 & 1.3 & 1.1 & 0.95 & 0.85 & 0.85 \\
\hline \multirow[t]{3}{*}{${ }^{34} \mathrm{~S}(\mathrm{p}, \gamma){ }^{35} \mathrm{Cl}$} & ${ }^{34} \mathrm{~S}$ & 0.019 & 0.19 & 0.69 & 1.3 & 1.6 & 1.8 \\
\hline & ${ }^{35} \mathrm{Cl}$ & 2.3 & 2.1 & 1.3 & 0.63 & 0.19 & 0.053 \\
\hline & ${ }^{36} \mathrm{Ar}$ & 1.4 & 1.3 & 1.1 & 0.90 & 0.80 & 0.75 \\
\hline \multirow[t]{2}{*}{${ }^{33} \mathrm{Cl}(\mathrm{p}, \gamma){ }^{34} \mathrm{Ar}$} & ${ }^{33} \mathrm{~S}$ & 0.74 & 1.0 & 1.0 & 1.0 & 1.0 & 1.0 \\
\hline & ${ }^{35} \mathrm{Cl}$ & 1.3 & 1.0 & 1.0 & 1.0 & 1.0 & 1.0 \\
\hline \multirow[t]{2}{*}{${ }^{34} \mathrm{Cl}(\mathrm{p}, \gamma){ }^{35} \mathrm{Ar}$} & ${ }^{34} \mathrm{~S}$ & 0.75 & 1.0 & 1.0 & 1.0 & 1.0 & 1.0 \\
\hline & ${ }^{35} \mathrm{Cl}$ & 1.3 & 1.0 & 1.0 & 1.0 & 1.0 & 1.0 \\
\hline${ }^{35} \mathrm{Cl}(\mathrm{p}, \gamma){ }^{36} \mathrm{Ar}$ & ${ }^{36} \mathrm{Ar}$ & $\cdots$ & $\ldots$ & 1.2 & 0.85 & $\ldots$ & $\ldots$ \\
\hline${ }^{36} \mathrm{Ar}(\mathrm{p}, \gamma){ }^{37} \mathrm{~K}$ & ${ }^{36} \mathrm{Ar}$ & $\ldots$ & $\ldots$ & 0.21 & 4.1 & $\cdots$ & $\cdots$ \\
\hline \multirow[t]{2}{*}{${ }^{37} \operatorname{Ar}(\mathrm{p}, \gamma){ }^{38} \mathrm{~K}$} & ${ }^{37} \mathrm{Ar}$ & 0.0084 & 0.19 & 0.81 & 1.1 & 1.2 & 1.3 \\
\hline & ${ }^{37} \mathrm{Cl}$ & 0.88 & 0.91 & 0.98 & 1.0 & 1.0 & 1.0 \\
\hline
\end{tabular}


Table 9-Continued

\begin{tabular}{|c|c|c|c|c|c|c|c|}
\hline \multirow[t]{2}{*}{ Reaction } & \multirow[t]{2}{*}{ Isotope i } & \multicolumn{6}{|c|}{ Reaction rate multiplied by } \\
\hline & & 100 & 10 & 2 & 0.5 & 0.1 & 0.01 \\
\hline \multirow{4}{*}{${ }^{38} \operatorname{Ar}(\mathrm{p}, \gamma){ }^{39} \mathrm{~K}$} & ${ }^{38} \mathrm{Ar}$ & 4.2 & 3.6 & 1.6 & 0.62 & 0.27 & 0.19 \\
\hline & ${ }^{39} \mathrm{~K}$ & 2.6 & 1.9 & 1.2 & 0.83 & 0.78 & 0.75 \\
\hline & ${ }^{38} \mathrm{Ar}$ & 0.63 & 0.79 & 0.95 & 1.0 & 1.1 & 1.1 \\
\hline & ${ }^{39} \mathrm{~K}$ & 3.6 & 2.4 & 1.3 & 0.77 & 0.58 & 0.53 \\
\hline${ }^{37} \mathrm{~K}(\mathrm{p}, \gamma)^{38} \mathrm{Ca}$ & ${ }^{38} \mathrm{Ar}$ & 1.2 & 1.0 & 1.0 & 1.0 & 1.0 & 1.0 \\
\hline \multirow[t]{2}{*}{${ }^{38} \mathrm{~K}(\mathrm{p}, \gamma){ }^{39} \mathrm{Ca}$} & ${ }^{38} \mathrm{Ar}$ & 0.37 & 0.85 & 0.98 & 1.0 & 1.0 & 1.0 \\
\hline & ${ }^{39} \mathrm{~K}$ & 5.9 & 2.2 & 1.2 & 0.92 & 0.83 & 0.82 \\
\hline${ }^{39} \mathrm{~K}(\mathrm{p}, \gamma){ }^{40} \mathrm{Ca}$ & ${ }^{39} \mathrm{~K}$ & 0.092 & 0.58 & 0.92 & 1.0 & 1.0 & 1.0 \\
\hline
\end{tabular}

NOTE.- See $\S 4$ for an explanation of the quantities listed here. 
Table 10. FINAL ABUNDANCE CHANGES $\mathrm{X}_{i} / \mathrm{X}_{i, \text { rec }}$ RESULTING FROM REACTION RATE VARIATIONS FOR CO NOVA MODEL JH1 ( $\left.\mathrm{T}_{P E A K}=0.145 \mathrm{GK}\right)$

\begin{tabular}{|c|c|c|c|c|c|c|c|}
\hline \multirow{2}{*}{ Reaction } & \multirow{2}{*}{ Isotope i } & \multicolumn{6}{|c|}{ Reaction rate multiplied by } \\
\hline & & 100 & 10 & 2 & 0.5 & 0.1 & 0.01 \\
\hline \multirow[t]{2}{*}{${ }^{3} \mathrm{He}(\alpha, \gamma){ }^{7} \mathrm{Be}$} & ${ }^{3} \mathrm{He}$ & $\cdots$ & $\cdots$ & 0.15 & 2.3 & $\cdots$ & $\cdots$ \\
\hline & ${ }^{7} \mathrm{Be}$ & $\ldots$ & $\cdots$ & 0.30 & 1.2 & $\cdots$ & \\
\hline${ }^{13} \mathrm{~N}(\mathrm{p}, \gamma){ }^{14} \mathrm{O}$ & ${ }^{13} \mathrm{C}$ & $\cdots$ & $\cdots$ & 0.85 & 1.2 & $\cdots$ & $\cdots$ \\
\hline \multirow[t]{4}{*}{${ }^{14} \mathrm{~N}(\mathrm{p}, \gamma){ }^{15} \mathrm{O}$} & ${ }^{12} \mathrm{C}$ & $\cdots$ & $\cdots$ & 1.60 & 0.59 & $\cdots$ & $\cdots$ \\
\hline & ${ }^{13} \mathrm{C}$ & $\cdots$ & $\cdots$ & 1.5 & 0.67 & $\cdots$ & $\cdots$ \\
\hline & ${ }^{14} \mathrm{~N}$ & $\cdots$ & $\cdots$ & 0.86 & 1.1 & $\cdots$ & $\cdots$ \\
\hline & ${ }^{15} \mathrm{~N}$ & $\ldots$ & $\ldots$ & 1.8 & 0.58 & $\cdots$ & $\cdots$ \\
\hline \multirow[t]{4}{*}{${ }^{16} \mathrm{O}(\mathrm{p}, \gamma){ }^{17} \mathrm{~F}$} & ${ }^{16} \mathrm{O}$ & $\ldots$ & $\cdots$ & 0.80 & 1.2 & $\cdots$ & $\cdots$ \\
\hline & ${ }^{17} \mathrm{O}$ & $\cdots$ & $\cdots$ & 1.7 & 0.54 & $\cdots$ & $\cdots$ \\
\hline & ${ }^{18} \mathrm{~F}$ & $\cdots$ & $\cdots$ & 1.7 & 0.55 & $\cdots$ & $\cdots$ \\
\hline & ${ }^{19} \mathrm{~F}$ & $\cdots$ & $\cdots$ & 1.6 & 0.55 & $\cdots$ & $\cdots$ \\
\hline \multirow{3}{*}{${ }^{17} \mathrm{O}(\mathrm{p}, \gamma){ }^{18} \mathrm{~F}$} & ${ }^{17} \mathrm{O}$ & $\cdots$ & 0.59 & 0.91 & 1.0 & 1.0 & \\
\hline & ${ }^{18} \mathrm{~F}$ & $\ldots$ & 5.8 & 1.9 & 0.53 & 0.11 & $\cdots$ \\
\hline & ${ }^{19} \mathrm{~F}$ & $\cdots$ & 5.9 & 1.9 & 0.53 & 0.11 & $\cdots$ \\
\hline \multirow[t]{4}{*}{${ }^{17} \mathrm{O}(\mathrm{p}, \alpha){ }^{14} \mathrm{~N}$} & ${ }^{14} \mathrm{~N}$ & $\ldots$ & 1.0 & 1.0 & 0.93 & 0.86 & $\ldots$ \\
\hline & ${ }^{17} \mathrm{O}$ & $\cdots$ & 0.050 & 0.39 & 2.0 & 4.3 & $\cdots$ \\
\hline & ${ }^{18} \mathrm{~F}$ & $\ldots$ & 0.053 & 0.39 & 2.1 & 4.5 & $\cdots$ \\
\hline & ${ }^{19} \mathrm{~F}$ & $\cdots$ & 0.057 & 0.42 & 2.0 & 4.1 & $\cdots$ \\
\hline${ }^{18} \mathrm{~F}(\mathrm{p}, \gamma){ }^{19} \mathrm{Ne}$ & ${ }^{19} \mathrm{~F}$ & $\ldots$ & 8.6 & 1.9 & 0.58 & 0.25 & \\
\hline \multirow[t]{2}{*}{${ }^{18} \mathrm{~F}(\mathrm{p}, \alpha)^{15} \mathrm{O}$} & ${ }^{18} \mathrm{~F}$ & 0.010 & 0.10 & 0.50 & 2.0 & 10.0 & $\cdots$ \\
\hline & ${ }^{19} \mathrm{~F}$ & 0.010 & 0.10 & 0.51 & 2.0 & 10.0 & $\cdots$ \\
\hline${ }^{19} \mathrm{~F}(\mathrm{p}, \alpha){ }^{16} \mathrm{O}$ & ${ }^{19} \mathrm{~F}$ & $\cdots$ & $\cdots$ & 0.52 & 2.0 & $\cdots$ & $\cdots$ \\
\hline \multirow{2}{*}{${ }^{20} \mathrm{Ne}(\mathrm{p}, \gamma){ }^{21} \mathrm{Na}$} & ${ }^{21} \mathrm{Ne}$ & $\cdots$ & $\cdots$ & 2.0 & 0.50 & $\cdots$ & $\cdots$ \\
\hline & ${ }^{22} \mathrm{Na}$ & $\cdots$ & $\cdots$ & 2.9 & 0.49 & $\cdots$ & $\cdots$ \\
\hline${ }^{21} \mathrm{Ne}(\mathrm{p}, \gamma)^{22} \mathrm{Na}$ & ${ }^{21} \mathrm{Ne}$ & $\cdots$ & $\cdots$ & 0.50 & 2.0 & $\cdots$ & $\cdots$ \\
\hline \multirow[t]{9}{*}{${ }^{22} \mathrm{Ne}(\mathrm{p}, \gamma)^{23} \mathrm{Na}$} & ${ }^{20} \mathrm{Ne}$ & 2.3 & 1.3 & 1.0 & 1.0 & $\cdots$ & $\cdots$ \\
\hline & ${ }^{21} \mathrm{Ne}$ & 2.3 & 1.3 & 1.0 & 1.0 & $\cdots$ & $\cdots$ \\
\hline & ${ }^{22} \mathrm{Ne}$ & 0.036 & 0.72 & 0.96 & 1.0 & $\cdots$ & $\cdots$ \\
\hline & ${ }^{22} \mathrm{Na}$ & 2.3 & 1.3 & 1.0 & 1.0 & $\cdots$ & \\
\hline & ${ }^{23} \mathrm{Na}$ & 5.9 & 6.9 & 1.9 & 0.56 & $\cdots$ & $\cdots$ \\
\hline & ${ }^{24} \mathrm{Mg}$ & 6.3 & 6.7 & 1.8 & 0.54 & $\cdots$ & $\cdots$ \\
\hline & ${ }^{25} \mathrm{Mg}$ & 2.3 & 1.3 & 1.0 & 0.98 & $\cdots$ & $\cdots$ \\
\hline & ${ }^{26} \mathrm{Al}$ & 2.0 & 1.2 & 1.1 & 1.0 & $\cdots$ & $\cdots$ \\
\hline & ${ }^{27} \mathrm{Al}$ & 1.2 & 1.0 & 1.0 & 1.0 & $\ldots$ & $\cdots$ \\
\hline${ }^{21} \mathrm{Na}(\mathrm{p}, \gamma){ }^{22} \mathrm{Mg}$ & ${ }^{21} \mathrm{Ne}$ & 0.87 & 1.0 & 1.0 & 1.0 & 1.0 & 1.0 \\
\hline${ }^{22} \mathrm{Na}(\mathrm{p}, \gamma)^{23} \mathrm{Mg}$ & ${ }^{22} \mathrm{Na}$ & $\cdots$ & $\cdots$ & 0.58 & 1.7 & $\cdots$ & $\cdots$ \\
\hline \multirow[t]{3}{*}{${ }^{23} \mathrm{Na}(\mathrm{p}, \gamma){ }^{24} \mathrm{Mg}$} & ${ }^{23} \mathrm{Na}$ & $\cdots$ & 0.31 & 0.79 & 1.1 & 1.3 & 1.3 \\
\hline & ${ }^{24} \mathrm{Mg}$ & $\cdots$ & 3.2 & 1.5 & 0.55 & 0.12 & 0.013 \\
\hline & ${ }^{25} \mathrm{Mg}$ & $\cdots$ & 1.2 & 1.0 & 0.98 & 1.0 & 1.0 \\
\hline \multirow[t]{2}{*}{${ }^{23} \mathrm{Na}(\mathrm{p}, \alpha)^{20} \mathrm{Ne}$} & ${ }^{23} \mathrm{Na}$ & $\ldots$ & $\cdots$ & 0.58 & 1.6 & $\ldots$ & $\cdots$ \\
\hline & ${ }^{24} \mathrm{Mg}$ & $\ldots$ & $\ldots$ & 0.55 & 1.5 & $\ldots$ & $\cdots$ \\
\hline \multirow[t]{2}{*}{${ }^{25} \mathrm{Mg}(\mathrm{p}, \gamma)^{26} \mathrm{Al}^{g}$} & ${ }^{26} \mathrm{Al}$ & $\cdots$ & $\cdots$ & 1.9 & 0.52 & $\cdots$ & $\cdots$ \\
\hline & ${ }^{27} \mathrm{Al}$ & $\cdots$ & $\cdots$ & 1.3 & 0.88 & $\cdots$ & $\cdots$ \\
\hline \multirow[t]{2}{*}{${ }^{26} \mathrm{Mg}(\mathrm{p}, \gamma){ }^{27} \mathrm{Al}$} & ${ }^{26} \mathrm{Mg}$ & $\cdots$ & 0.091 & 0.72 & 1.2 & $\cdots$ & $\cdots$ \\
\hline & ${ }^{27} \mathrm{Al}$ & $\cdots$ & 1.6 & 1.2 & 0.88 & $\cdots$ & $\cdots$ \\
\hline \multirow[t]{2}{*}{${ }^{26} \mathrm{Al}^{g}(\mathrm{p}, \gamma){ }^{27} \mathrm{Si}$} & ${ }^{26} \mathrm{Al}$ & $\cdots$ & 0.10 & 0.59 & 1.4 & $\cdots$ & $\cdots$ \\
\hline & ${ }^{27} \mathrm{Al}$ & $\cdots$ & 1.2 & 1.1 & 0.90 & $\cdots$ & $\cdots$ \\
\hline
\end{tabular}


Table 10-Continued

\begin{tabular}{|c|c|c|c|c|c|c|c|}
\hline \multirow[t]{2}{*}{ Reaction } & \multirow[t]{2}{*}{ Isotope $\mathrm{i}$} & \multicolumn{6}{|c|}{ Reaction rate multiplied by } \\
\hline & & 100 & 10 & 2 & 0.5 & 0.1 & 0.01 \\
\hline${ }^{27} \mathrm{Al}(\mathrm{p}, \gamma){ }^{28} \mathrm{Si}$ & ${ }^{27} \mathrm{Al}$ & $\ldots$ & $\ldots$ & 0.74 & 1.2 & $\ldots$ & $\cdots$ \\
\hline${ }^{29} \mathrm{Si}(\mathrm{p}, \gamma){ }^{30} \mathrm{P}$ & ${ }^{30} \mathrm{Si}$ & $\cdots$ & 1.2 & 1.0 & 1.0 & 1.0 & $\cdots$ \\
\hline${ }^{33} \mathrm{~S}(\mathrm{p}, \gamma){ }^{34} \mathrm{Cl}$ & ${ }^{33} \mathrm{~S}$ & 0.71 & 1.0 & 1.0 & 1.0 & 1.0 & 1.0 \\
\hline \multirow[t]{2}{*}{${ }^{34} \mathrm{~S}(\mathrm{p}, \gamma){ }^{35} \mathrm{Cl}$} & ${ }^{34} \mathrm{~S}$ & 0.71 & 1.0 & 1.0 & 1.0 & 1.0 & 1.0 \\
\hline & ${ }^{35} \mathrm{Cl}$ & 3.1 & 1.2 & 1.1 & 1.0 & 1.0 & 1.0 \\
\hline${ }^{36} \operatorname{Ar}(\mathrm{p}, \gamma){ }^{37} \mathrm{~K}$ & ${ }^{37} \mathrm{Ar}$ & $\ldots$ & $\ldots$ & 1.8 & 0.62 & $\ldots$ & $\ldots$ \\
\hline
\end{tabular}

NOTE.- See $\S 4$ for an explanation of the quantities listed here. 
Table 11. FINAL ABUNDANCE CHANGES X $\mathrm{X}_{i} / \mathrm{X}_{\text {,rec }}$ RESULTING FROM REACTION RATE VARIATIONS FOR CO NOVA MODEL JH2 $\left(\mathrm{T}_{P E A K}=0.170 \mathrm{GK}\right)$

\begin{tabular}{|c|c|c|c|c|c|c|c|}
\hline \multirow[t]{2}{*}{ Reaction } & \multirow[t]{2}{*}{ Isotope i } & \multicolumn{6}{|c|}{ Reaction rate multiplied by } \\
\hline & & 100 & 10 & 2 & 0.5 & 0.1 & 0.01 \\
\hline \multirow[t]{2}{*}{${ }^{3} \mathrm{He}(\alpha, \gamma)^{7} \mathrm{Be}$} & ${ }^{3} \mathrm{He}$ & $\ldots$ & & 0.19 & 2.1 & & $\ldots$ \\
\hline & ${ }^{7} \mathrm{Be}$ & $\ldots$ & $\ldots$ & 1.3 & 0.66 & $\ldots$ & $\ldots$ \\
\hline${ }^{7} \mathrm{Be}(\mathrm{p}, \gamma){ }^{8} \mathrm{~B}$ & ${ }^{7} \mathrm{Be}$ & $\ldots$ & $\ldots$ & 0.41 & 2.2 & $\ldots$ & $\ldots$ \\
\hline${ }^{8} \mathrm{~B}(\mathrm{p}, \gamma){ }^{9} \mathrm{C}$ & ${ }^{7} \mathrm{Be}$ & $\ldots$ & 0.80 & 0.98 & 1.0 & 1.0 & $\ldots$ \\
\hline${ }^{13} \mathrm{~N}(\mathrm{p}, \gamma)^{14} \mathrm{O}$ & ${ }^{13} \mathrm{C}$ & $\ldots$ & $\ldots$ & 0.86 & 1.1 & $\ldots$ & $\ldots$ \\
\hline \multirow{3}{*}{${ }^{14} \mathrm{~N}(\mathrm{p}, \gamma){ }^{15} \mathrm{O}$} & ${ }^{12} \mathrm{C}$ & $\ldots$ & $\ldots$ & 1.4 & 0.65 & $\ldots$ & $\ldots$ \\
\hline & ${ }^{13} \mathrm{C}$ & $\ldots$ & $\ldots$ & 1.2 & 0.76 & $\ldots$ & $\ldots$ \\
\hline & ${ }^{15} \mathrm{~N}$ & $\ldots$ & $\ldots$ & 1.6 & 0.64 & $\ldots$ & $\ldots$ \\
\hline${ }^{15} \mathrm{~N}(\mathrm{p}, \alpha)^{12} \mathrm{C}$ & ${ }^{15} \mathrm{~N}$ & $\ldots$ & $\ldots$ & 0.49 & 2.1 & $\ldots$ & $\ldots$ \\
\hline \multirow[t]{4}{*}{${ }^{16} \mathrm{O}(\mathrm{p}, \gamma)^{17} \mathrm{~F}$} & ${ }^{16} \mathrm{O}$ & $\ldots$ & $\ldots$ & 0.79 & 1.2 & $\ldots$ & $\ldots$ \\
\hline & ${ }^{17} \mathrm{O}$ & $\ldots$ & $\ldots$ & 1.8 & 0.55 & $\ldots$ & $\ldots$ \\
\hline & ${ }^{18} \mathrm{~F}$ & $\ldots$ & & 1.7 & 0.53 & $\ldots$ & \\
\hline & ${ }^{19} \mathrm{~F}$ & $\ldots$ & $\ldots$ & 1.7 & 0.55 & $\ldots$ & $\ldots$ \\
\hline \multirow[t]{3}{*}{${ }^{17} \mathrm{O}(\mathrm{p}, \gamma){ }^{18} \mathrm{~F}$} & ${ }^{17} \mathrm{O}$ & $\ldots$ & 0.55 & 0.90 & 1.1 & 1.1 & $\ldots$ \\
\hline & ${ }^{18} \mathrm{~F}$ & $\ldots$ & 5.2 & 1.8 & 0.51 & 0.11 & $\ldots$ \\
\hline & ${ }^{19} \mathrm{~F}$ & $\ldots$ & 5.5 & 1.8 & 0.52 & 0.11 & $\ldots$ \\
\hline \multirow{3}{*}{${ }^{17} \mathrm{O}(\mathrm{p}, \alpha){ }^{14} \mathrm{~N}$} & ${ }^{17} \mathrm{O}$ & $\ldots$ & 0.035 & 0.48 & 1.6 & 2.4 & $\ldots$ \\
\hline & ${ }^{18} \mathrm{~F}$ & $\ldots$ & 0.036 & 0.48 & 1.5 & 2.3 & $\ldots$ \\
\hline & ${ }^{19} \mathrm{~F}$ & $\ldots$ & 0.048 & 0.52 & 1.5 & 2.2 & \\
\hline${ }^{18} \mathrm{~F}(\mathrm{p}, \gamma){ }^{19} \mathrm{Ne}$ & ${ }^{19} \mathrm{~F}$ & $\ldots$ & 9.1 & 1.9 & 0.55 & 0.20 & $\cdots$ \\
\hline \multirow[t]{2}{*}{${ }^{18} \mathrm{~F}(\mathrm{p}, \alpha){ }^{15} \mathrm{O}$} & ${ }^{18} \mathrm{~F}$ & 0.011 & 0.11 & 0.51 & 1.9 & 9.4 & 78 \\
\hline & ${ }^{19} \mathrm{~F}$ & 0.010 & 0.10 & 0.48 & 2.0 & 10 & 82 \\
\hline${ }^{19} \mathrm{~F}(\mathrm{p}, \alpha){ }^{16} \mathrm{O}$ & ${ }^{19} \mathrm{~F}$ & $\ldots$ & $\ldots$ & 0.58 & 1.8 & $\ldots$ & $\ldots$ \\
\hline \multirow[t]{2}{*}{${ }^{20} \mathrm{Ne}(\mathrm{p}, \gamma)^{21} \mathrm{Na}$} & ${ }^{21} \mathrm{Ne}$ & $\ldots$ & $\cdots$ & 2.0 & 0.48 & $\cdots$ & $\cdots$ \\
\hline & ${ }^{22} \mathrm{Na}$ & $\ldots$ & $\ldots$ & 2.0 & 0.50 & $\ldots$ & $\ldots$ \\
\hline${ }^{21} \mathrm{Ne}(\mathrm{p}, \gamma){ }^{22} \mathrm{Na}$ & ${ }^{21} \mathrm{Ne}$ & $\ldots$ & $\ldots$ & 0.52 & 1.8 & $\ldots$ & $\ldots$ \\
\hline \multirow[t]{10}{*}{${ }^{22} \mathrm{Ne}(\mathrm{p}, \gamma)^{23} \mathrm{Na}$} & ${ }^{20} \mathrm{Ne}$ & 4.3 & 2.1 & 1.1 & 0.92 & 0.86 & $\ldots$ \\
\hline & ${ }^{21} \mathrm{Ne}$ & 4.4 & 2.1 & 1.1 & 0.92 & 0.84 & $\cdots$ \\
\hline & ${ }^{22} \mathrm{Na}$ & 4.4 & 2.0 & 1.1 & 0.92 & 0.86 & \\
\hline & ${ }^{22} \mathrm{Ne}$ & 0.0085 & 0.65 & 0.96 & 1.0 & 1.0 & \\
\hline & ${ }^{23} \mathrm{Na}$ & 1.4 & 6.7 & 1.9 & 0.52 & 0.14 & $\cdots$ \\
\hline & ${ }^{24} \mathrm{Mg}$ & 1.4 & 6.2 & 1.8 & 0.51 & 0.13 & $\cdots$ \\
\hline & ${ }^{25} \mathrm{Mg}$ & 5.2 & 2.6 & 1.2 & 0.92 & 0.80 & $\ldots$ \\
\hline & ${ }^{26} \mathrm{Al}$ & 4.8 & 2.1 & 1.1 & 0.94 & 0.87 & $\ldots$ \\
\hline & ${ }^{26} \mathrm{Mg}$ & 2.8 & 1.5 & 1.1 & 0.94 & 0.94 & $\ldots$ \\
\hline & ${ }^{27} \mathrm{Al}$ & 3.2 & 1.5 & 1.1 & 0.97 & 0.95 & $\cdots$ \\
\hline${ }^{22} \mathrm{Na}(\mathrm{p}, \gamma)^{23} \mathrm{Mg}$ & ${ }^{22} \mathrm{Na}$ & $\ldots$ & $\ldots$ & 0.59 & 1.7 & $\ldots$ & $\ldots$ \\
\hline \multirow[t]{9}{*}{${ }^{23} \mathrm{Na}(\mathrm{p}, \gamma){ }^{24} \mathrm{Mg}$} & ${ }^{20} \mathrm{Ne}$ & $\cdots$ & 0.88 & 0.96 & 1.0 & 1.0 & 1.0 \\
\hline & ${ }^{21} \mathrm{Ne}$ & $\ldots$ & 0.88 & 0.96 & 1.0 & 1.0 & 1.0 \\
\hline & ${ }^{22} \mathrm{Na}$ & $\ldots$ & 0.88 & 0.97 & 1.0 & 1.0 & 1.0 \\
\hline & ${ }^{23} \mathrm{Na}$ & $\ldots$ & 0.37 & 0.86 & 1.1 & 1.2 & 1.3 \\
\hline & ${ }^{24} \mathrm{Mg}$ & $\ldots$ & 3.5 & 1.6 & 0.54 & 0.12 & 0.013 \\
\hline & ${ }^{25} \mathrm{Mg}$ & $\ldots$ & 1.5 & 1.2 & 0.92 & 0.80 & 0.76 \\
\hline & ${ }^{26} \mathrm{Al}$ & $\ldots$ & 1.4 & 1.1 & 0.94 & 0.87 & 0.87 \\
\hline & ${ }^{26} \mathrm{Mg}$ & $\ldots$ & 1.2 & 1.1 & 0.94 & 0.89 & 0.89 \\
\hline & ${ }^{27} \mathrm{Al}$ & $\ldots$ & 1.2 & 1.0 & 0.97 & 0.95 & 0.93 \\
\hline${ }^{23} \mathrm{Na}(\mathrm{p}, \alpha){ }^{20} \mathrm{Ne}$ & ${ }^{23} \mathrm{Na}$ & $\ldots$ & $\ldots$ & 0.62 & 1.5 & $\ldots$ & $\ldots$ \\
\hline
\end{tabular}


Table 11 - Continued

\begin{tabular}{|c|c|c|c|c|c|c|c|}
\hline \multirow[t]{2}{*}{ Reaction } & \multirow[t]{2}{*}{ Isotope i } & \multicolumn{6}{|c|}{ Reaction rate multiplied by } \\
\hline & & 100 & 10 & 2 & 0.5 & 0.1 & 0.01 \\
\hline \multirow{6}{*}{${ }^{25} \mathrm{Mg}(\mathrm{p}, \gamma)^{26} \mathrm{Al}^{g}$} & ${ }^{24} \mathrm{Mg}$ & $\cdots$ & $\cdots$ & 0.58 & 1.5 & $\cdots$ & $\cdots$ \\
\hline & ${ }^{25} \mathrm{Mg}$ & $\cdots$ & $\cdots$ & 0.92 & 1.2 & $\cdots$ & $\ldots$ \\
\hline & ${ }^{25} \mathrm{Mg}$ & $\cdots$ & $\ldots$ & 0.72 & 1.2 & $\ldots$ & $\ldots$ \\
\hline & ${ }^{26} \mathrm{Al}$ & $\cdots$ & $\ldots$ & 1.6 & 0.58 & $\ldots$ & $\cdots$ \\
\hline & ${ }^{26} \mathrm{Mg}$ & $\ldots$ & $\cdots$ & 0.89 & 1.1 & $\cdots$ & $\cdots$ \\
\hline & ${ }^{27} \mathrm{Al}$ & $\cdots$ & $\cdots$ & 1.4 & 0.73 & $\cdots$ & $\cdots$ \\
\hline${ }^{25} \mathrm{Mg}(\mathrm{p}, \gamma){ }^{26} \mathrm{Al}^{m}$ & ${ }^{26} \mathrm{Mg}$ & $\ldots$ & $\ldots$ & 1.4 & 0.72 & $\cdots$ & $\cdots$ \\
\hline${ }^{26} \mathrm{Mg}(\mathrm{p}, \gamma){ }^{27} \mathrm{Al}$ & ${ }^{26} \mathrm{Mg}$ & $\cdots$ & 0.072 & 0.43 & 1.7 & $\ldots$ & $\ldots$ \\
\hline \multirow[t]{2}{*}{${ }^{26} \mathrm{Al}^{g}(\mathrm{p}, \gamma){ }^{27} \mathrm{Si}$} & ${ }^{26} \mathrm{Al}$ & $\ldots$ & 0.048 & 0.45 & 1.7 & $\ldots$ & $\ldots$ \\
\hline & ${ }^{27} \mathrm{Al}$ & $\ldots$ & 1.2 & 1.1 & 0.83 & $\ldots$ & $\ldots$ \\
\hline${ }^{26} \mathrm{Al}^{m}(\mathrm{p}, \gamma){ }^{27} \mathrm{Si}$ & ${ }^{26} \mathrm{Mg}$ & 0.56 & 0.83 & 0.94 & 1.0 & 1.0 & 1.0 \\
\hline \multirow[t]{2}{*}{${ }^{29} \mathrm{Si}(\mathrm{p}, \gamma){ }^{30} \mathrm{P}$} & ${ }^{29} \mathrm{Si}$ & $\cdots$ & 0.45 & 0.94 & 1.1 & 1.1 & $\cdots$ \\
\hline & ${ }^{30} \mathrm{Si}$ & $\cdots$ & 1.7 & 1.2 & 1.0 & 0.92 & $\ldots$ \\
\hline${ }^{33} \mathrm{~S}(\mathrm{p}, \gamma){ }^{34} \mathrm{Cl}$ & ${ }^{33} \mathrm{~S}$ & 0.38 & 0.94 & 1.0 & 1.0 & 1.0 & 1.0 \\
\hline \multirow{2}{*}{${ }^{34} \mathrm{~S}(\mathrm{p}, \gamma){ }^{35} \mathrm{Cl}$} & ${ }^{34} \mathrm{~S}$ & 0.40 & 0.92 & 1.0 & 1.0 & 1.0 & 1.0 \\
\hline & ${ }^{35} \mathrm{Cl}$ & 5.4 & 1.6 & 1.1 & 1.0 & 1.0 & 1.0 \\
\hline
\end{tabular}

NOTE.- See $\S 4$ for an explanation of the quantities listed here. 
Table 12. INFLUENCE OF REACTION RATE VARIATIONS ON ISOTOPIC ABUNDANCES IN NOVA NUCLEOSYNTHESIS ${ }^{a}$

\begin{tabular}{|c|c|}
\hline REACTION RATE VARIATION ${ }^{b}$ & ISOTOPIC ABUNDANCE CHANGE $^{c}$ \\
\hline \multicolumn{2}{|c|}{ CO NOVA MODELS } \\
\hline${ }^{17} \mathrm{O}(\mathrm{p}, \gamma){ }^{18} \mathrm{~F}$ & ${ }^{18} \mathrm{~F}$ \\
\hline${ }^{17} \mathrm{O}(\mathrm{p}, \alpha)^{14} \mathrm{~N}$ & ${ }^{17} \mathrm{O},{ }^{18} \mathrm{~F}$ \\
\hline${ }^{18} \mathrm{~F}(\mathrm{p}, \alpha){ }^{15} \mathrm{O}$ & ${ }^{18} \mathrm{~F}$ \\
\hline${ }^{22} \mathrm{Ne}(\mathrm{p}, \gamma){ }^{23} \mathrm{Na}$ & ${ }^{22} \mathrm{Ne},{ }^{23} \mathrm{Na},{ }^{24} \mathrm{Mg},{ }^{25} \mathrm{Mg},{ }^{26} \mathrm{Al}$ \\
\hline${ }^{23} \mathrm{Na}(\mathrm{p}, \gamma){ }^{24} \mathrm{Mg}$ & ${ }^{24} \mathrm{Mg}$ \\
\hline${ }^{26} \mathrm{Mg}(\mathrm{p}, \gamma){ }^{27} \mathrm{Al}$ & ${ }^{26} \mathrm{Mg}$ \\
\hline${ }^{26} \mathrm{Al}^{g}(\mathrm{p}, \gamma){ }^{27} \mathrm{Si}$ & ${ }^{26} \mathrm{Al}$ \\
\hline \multicolumn{2}{|c|}{ ONE NOVA MODELS } \\
\hline${ }^{17} \mathrm{O}(\mathrm{p}, \gamma){ }^{18} \mathrm{~F}$ & ${ }^{17} \mathrm{O},{ }^{18} \mathrm{~F}$ \\
\hline${ }^{17} \mathrm{O}(\mathrm{p}, \alpha){ }^{14} \mathrm{~N}$ & ${ }^{17} \mathrm{O},{ }^{18} \mathrm{~F}$ \\
\hline${ }^{17} \mathrm{~F}(\mathrm{p}, \gamma){ }^{18} \mathrm{Ne}$ & ${ }^{17} \mathrm{O},{ }^{18} \mathrm{~F}$ \\
\hline${ }^{18} \mathrm{~F}(\mathrm{p}, \alpha){ }^{15} \mathrm{O}$ & ${ }^{16} \mathrm{O},{ }^{17} \mathrm{O},{ }^{18} \mathrm{~F}$ \\
\hline${ }^{21} \mathrm{Na}(\mathrm{p}, \gamma){ }^{22} \mathrm{Mg}$ & ${ }^{21} \mathrm{Ne},{ }^{22} \mathrm{Na},{ }^{22} \mathrm{Ne}$ \\
\hline${ }^{22} \mathrm{Ne}(\mathrm{p}, \gamma){ }^{23} \mathrm{Na}$ & ${ }^{22} \mathrm{Ne}$ \\
\hline${ }^{23} \mathrm{Na}(\mathrm{p}, \gamma){ }^{24} \mathrm{Mg}$ & ${ }^{20} \mathrm{Ne},{ }^{21} \mathrm{Ne},{ }^{22} \mathrm{Na},{ }^{23} \mathrm{Na},{ }^{24} \mathrm{Mg},{ }^{25} \mathrm{Mg},{ }^{26} \mathrm{Mg},{ }^{26} \mathrm{Al},{ }^{27} \mathrm{Al}$ \\
\hline${ }^{23} \mathrm{Mg}(\mathrm{p}, \gamma){ }^{24} \mathrm{Al}$ & ${ }^{20} \mathrm{Ne},{ }^{21} \mathrm{Ne},{ }^{22} \mathrm{Na},{ }^{23} \mathrm{Na},{ }^{24} \mathrm{Mg}$ \\
\hline${ }^{26} \mathrm{Mg}(\mathrm{p}, \gamma){ }^{27} \mathrm{Al}$ & ${ }^{26} \mathrm{Mg}$ \\
\hline${ }^{26} \mathrm{Al}^{g}(\mathrm{p}, \gamma){ }^{27} \mathrm{Si}$ & ${ }^{26} \mathrm{Al}$ \\
\hline${ }^{26} \mathrm{Al}^{m}(\mathrm{p}, \gamma)^{27} \mathrm{Si}$ & ${ }^{26} \mathrm{Mg}$ \\
\hline${ }^{29} \mathrm{Si}(\mathrm{p}, \gamma){ }^{30} \mathrm{P}$ & ${ }^{29} \mathrm{Si}$ \\
\hline${ }^{30} \mathrm{P}(\mathrm{p}, \gamma){ }^{31} \mathrm{~S}$ & ${ }^{30} \mathrm{Si},{ }^{32} \mathrm{~S},{ }^{33} \mathrm{~S},{ }^{34} \mathrm{~S},{ }^{35} \mathrm{Cl},{ }^{37} \mathrm{Cl},{ }^{36} \mathrm{Ar},{ }^{37} \mathrm{Ar},{ }^{38} \mathrm{Ar}$ \\
\hline${ }^{33} \mathrm{~S}(\mathrm{p}, \gamma){ }^{34} \mathrm{Cl}$ & ${ }^{33} \mathrm{~S},{ }^{34} \mathrm{~S},{ }^{35} \mathrm{Cl},{ }^{36} \mathrm{Ar}$ \\
\hline${ }^{33} \mathrm{Cl}(\mathrm{p}, \gamma){ }^{34} \mathrm{Ar}$ & ${ }^{33} \mathrm{~S}$ \\
\hline${ }^{34} \mathrm{~S}(\mathrm{p}, \gamma){ }^{35} \mathrm{Cl}$ & ${ }^{34} \mathrm{~S},{ }^{35} \mathrm{Cl},{ }^{36} \mathrm{Ar}$ \\
\hline${ }^{34} \mathrm{Cl}(\mathrm{p}, \gamma){ }^{35} \mathrm{Ar}$ & ${ }^{34} \mathrm{~S}$ \\
\hline${ }^{37} \operatorname{Ar}(\mathrm{p}, \gamma){ }^{38} \mathrm{~K}$ & ${ }^{37} \mathrm{Cl},{ }^{37} \mathrm{Ar},{ }^{38} \mathrm{Ar}$ \\
\hline${ }^{38} \mathrm{~K}(\mathrm{p}, \gamma){ }^{39} \mathrm{Ca}$ & ${ }^{38} \mathrm{Ar}$ \\
\hline
\end{tabular}

${ }^{\mathrm{a}}$ The table provides only a qualitative overview for some of our results; see Tables $5-11$ and $\S 5$ for complete quantitative results.

${ }^{b}$ Only those reactions are listed which have a significant influence on isotopic abundances in at least one of the nova models considered in the present work (Table 1).

${ }^{\mathrm{c}}$ Only those isotopes are listed whose abundances change by more than a factor of 2 as a result of varying the corresponding reaction rates within their adopted errors (Table 3). 


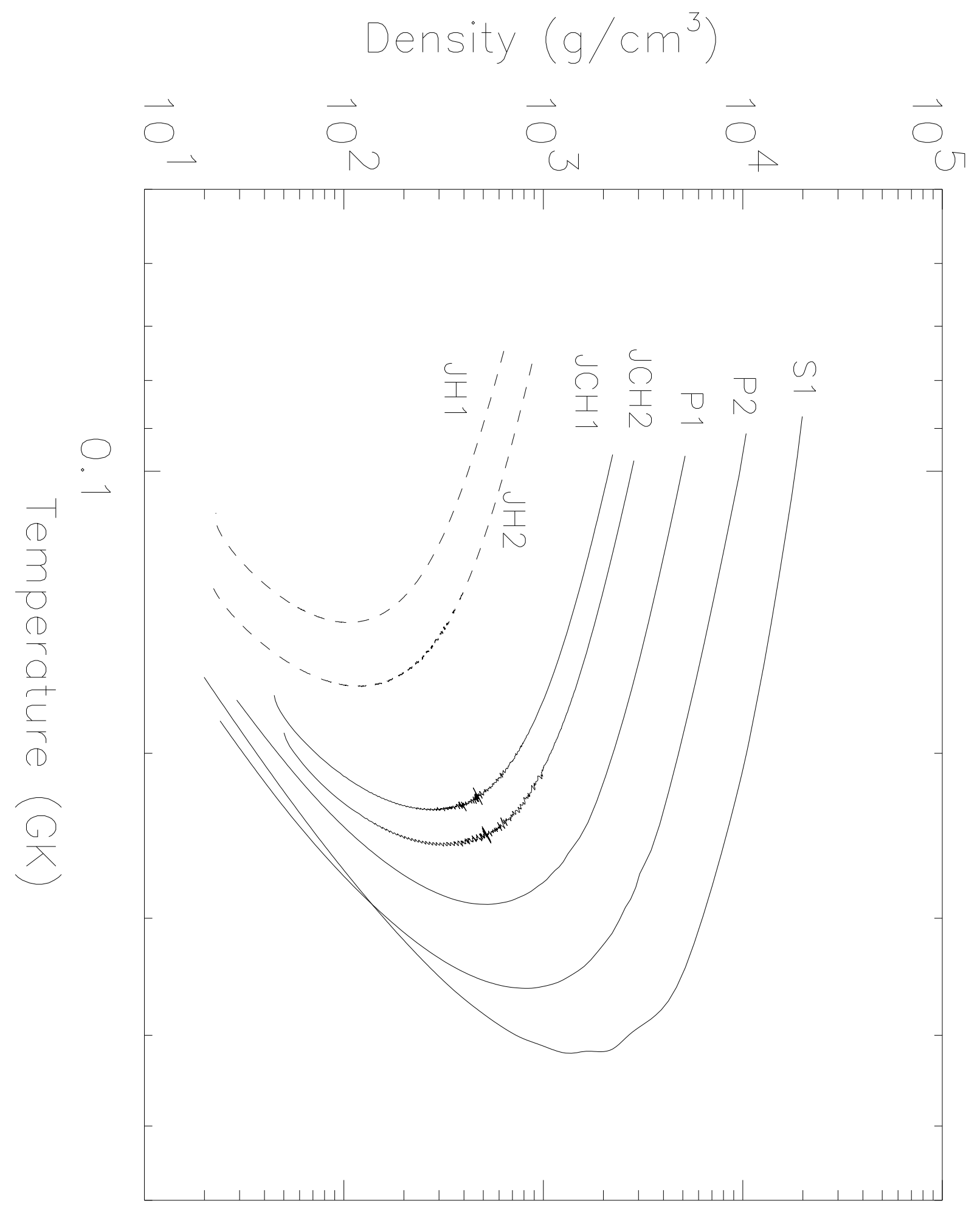




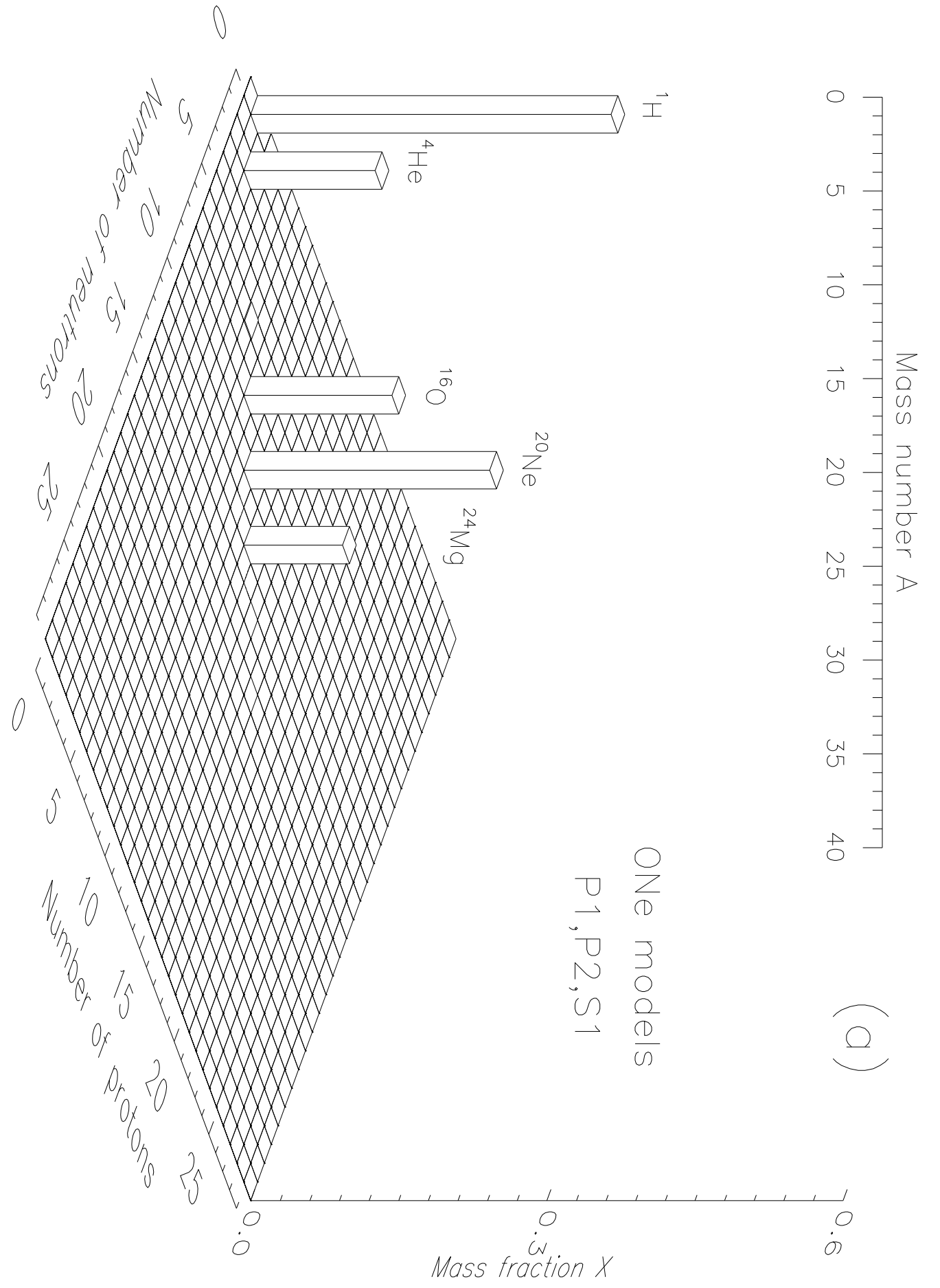




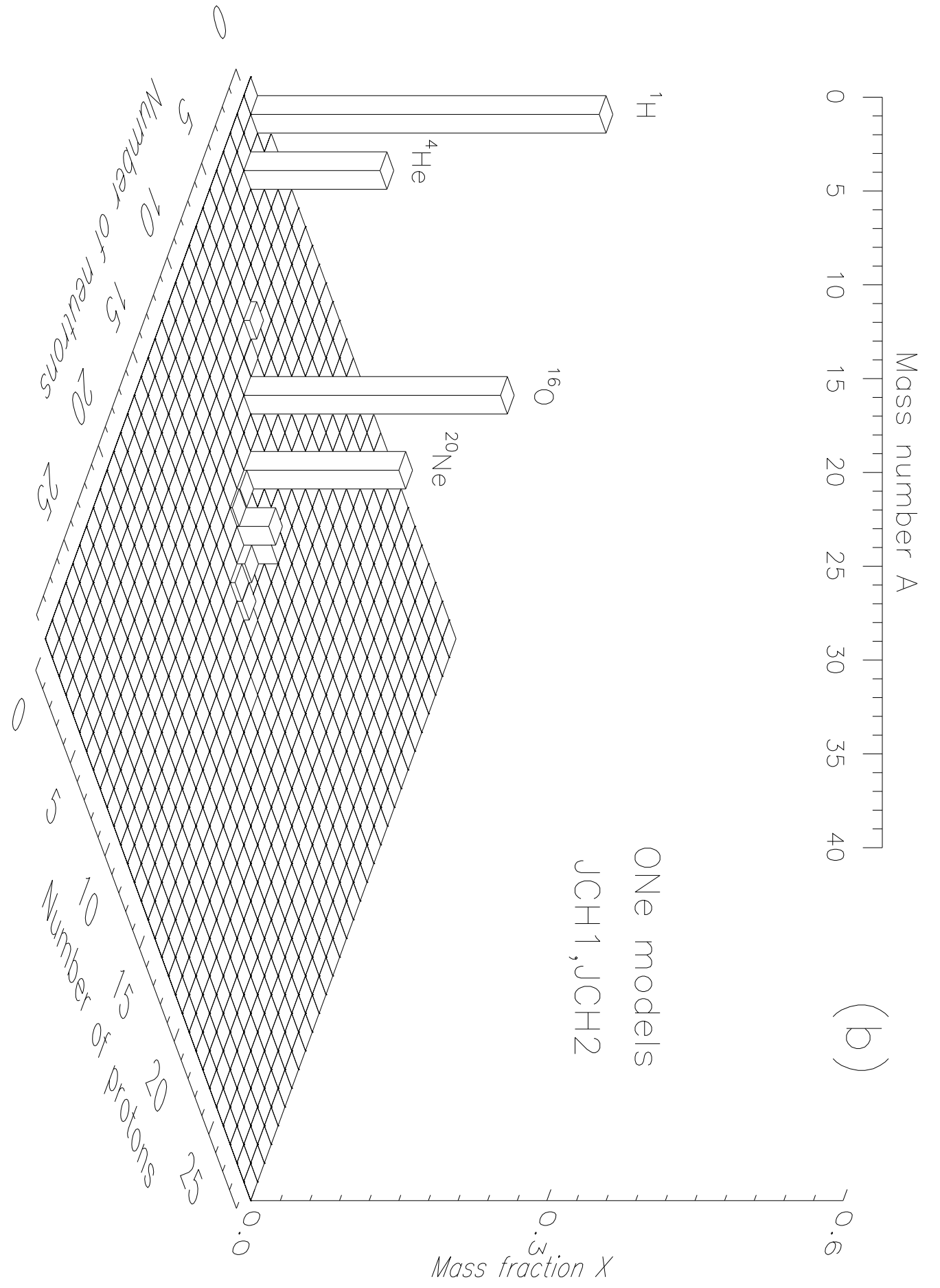




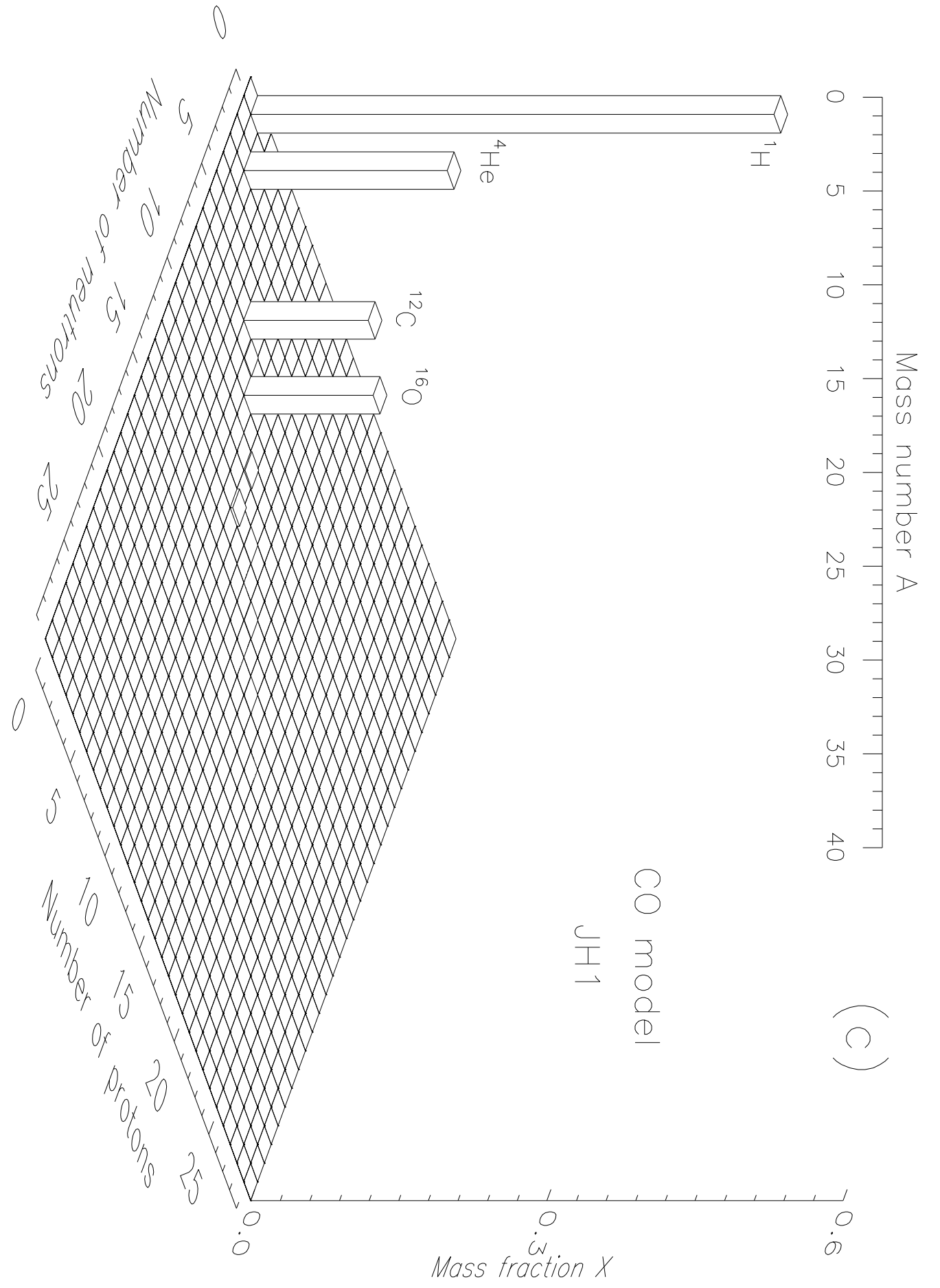




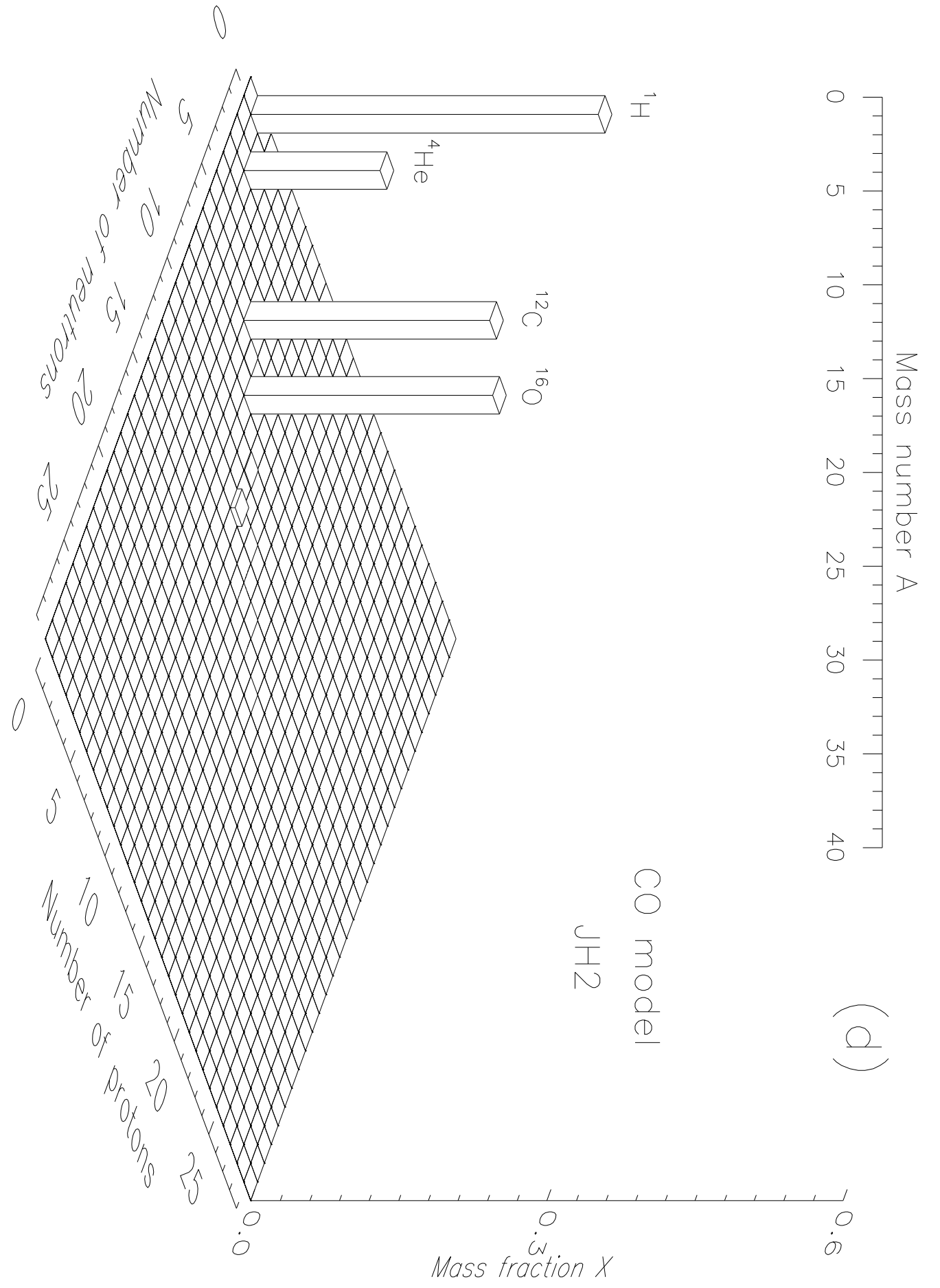




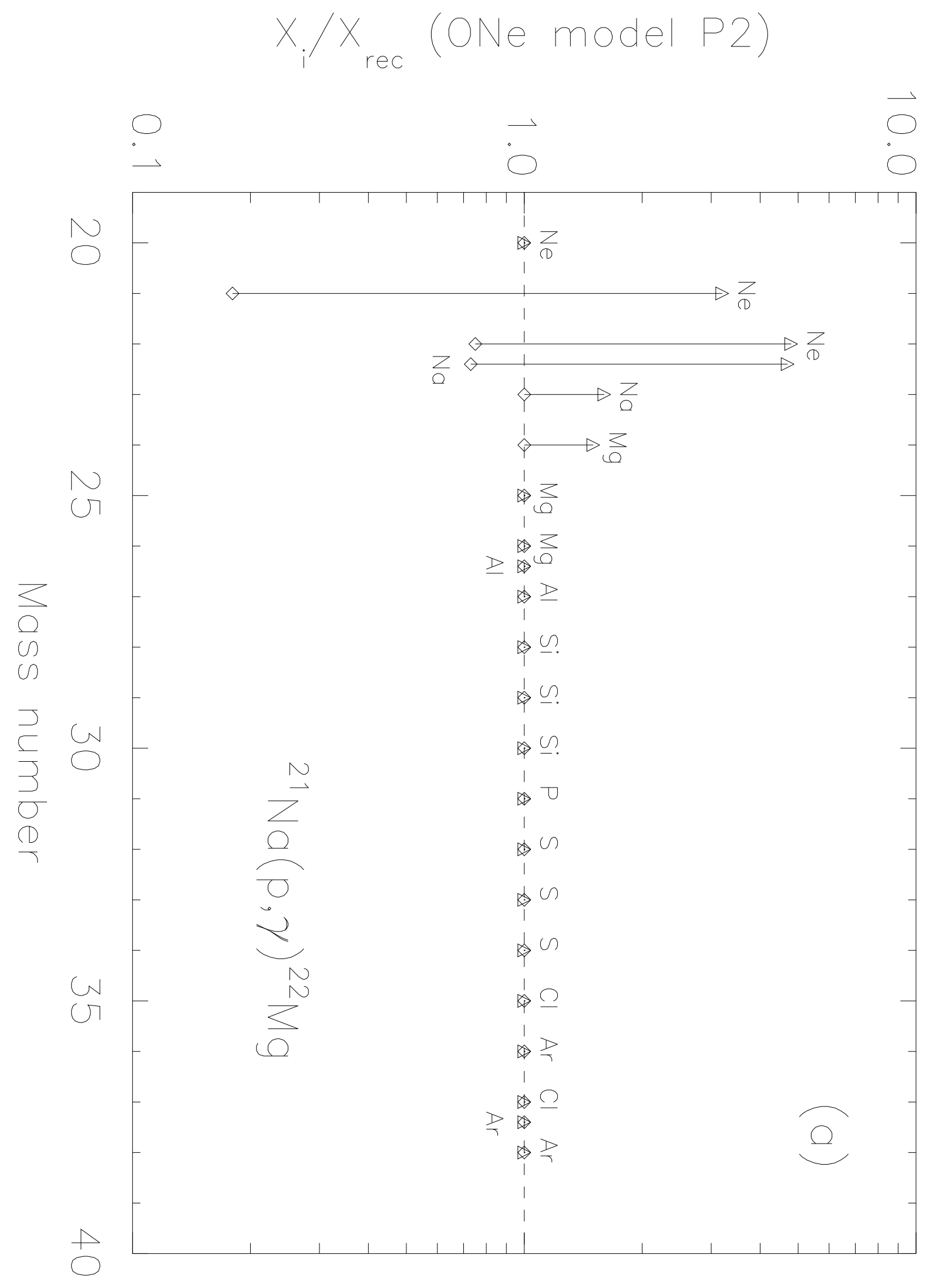




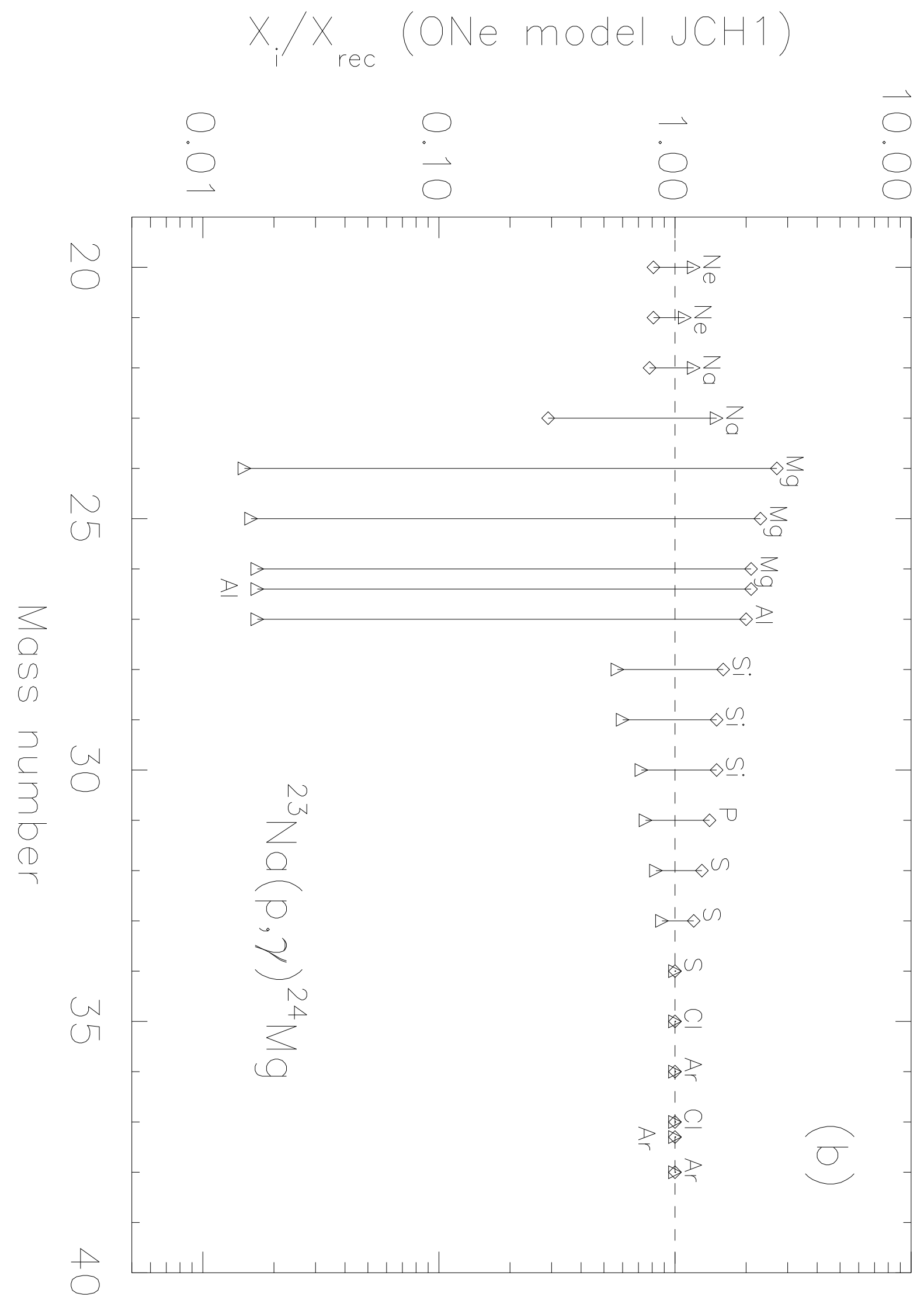




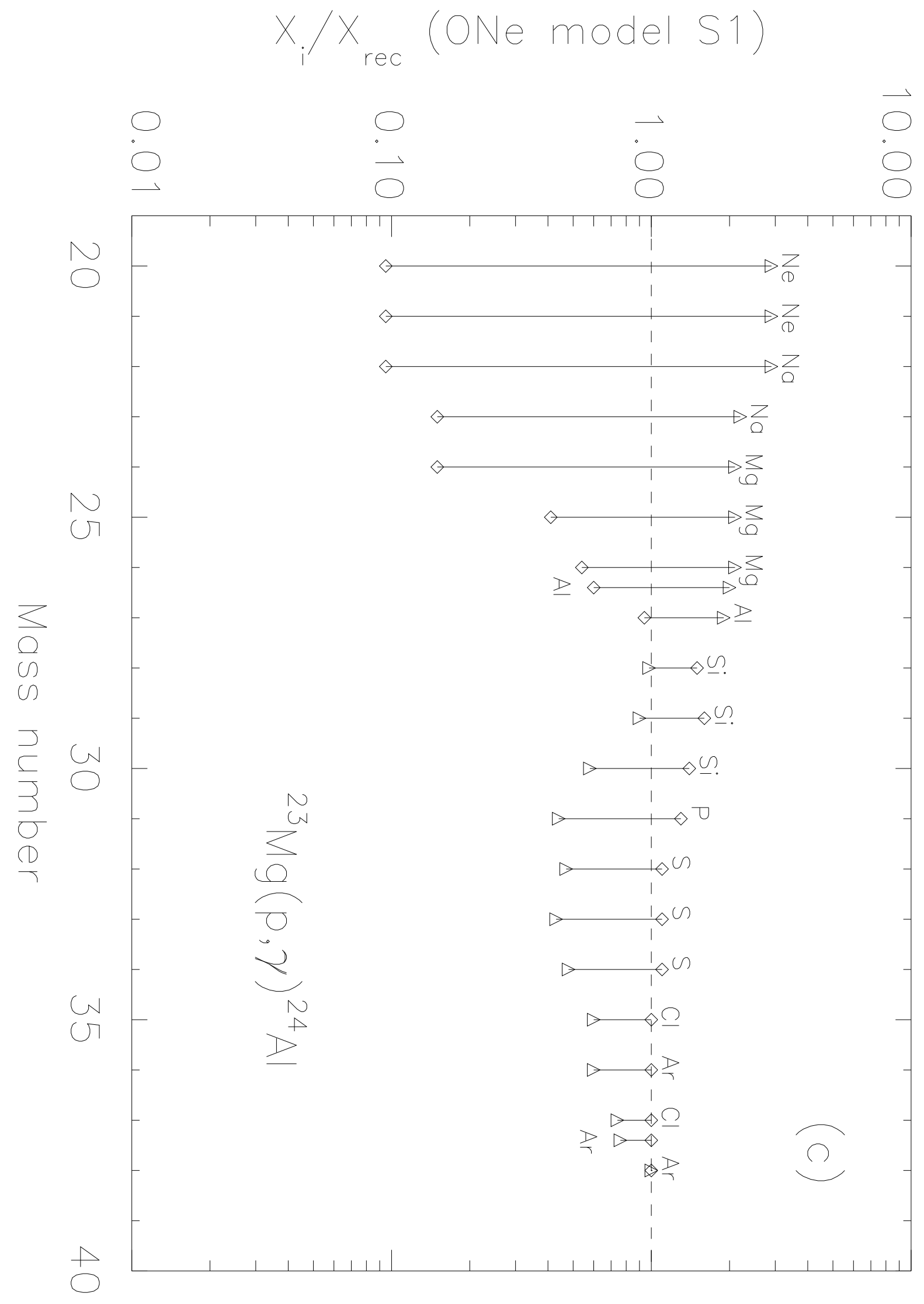




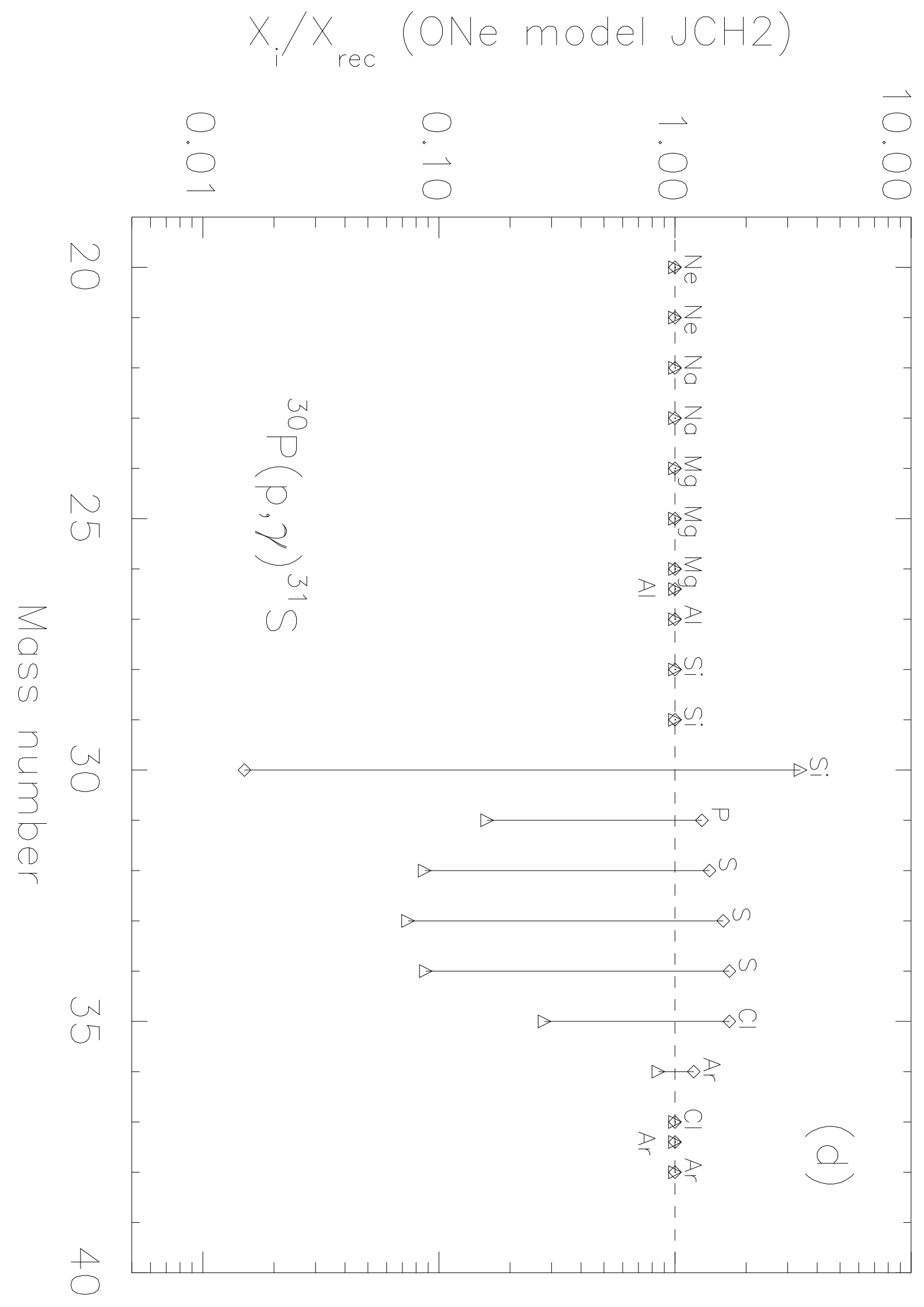




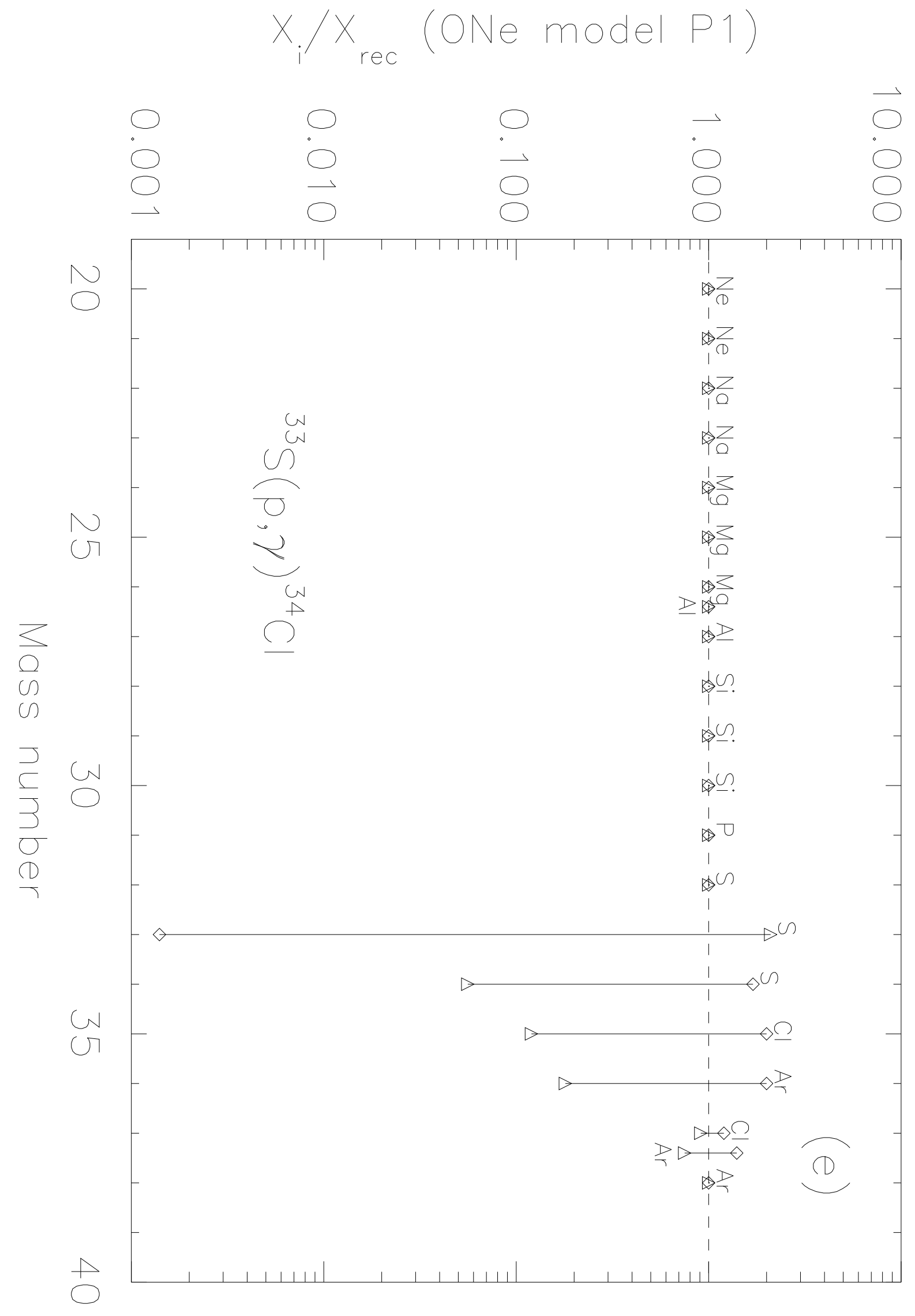

